\title{
Cultivating care: Exploring the patchy Anthropocene in four community gardens in Wellington, Aotearoa New Zealand
}

\author{
BY ZÖ̈ HEINE
}

A thesis submitted to the Victoria University of Wellington in fulfilment of the requirements for the degree of Master of Science in Science in Society

Centre for Science in Society

Victoria University of Wellington - Te Herenga Waka

2020 


\section{Acknowledgements}

I wish to acknowledge my supervisors, Dr James Beattie and Dr Tim Corballis, for their support throughout the process. I wish to thank the Centre of Science in Society, particular Maria for ensuring there was always coffee and tea. I would like to acknowledge The Garden History Research Foundation and the Australian Garden History Society for supporting my work. Thank you to Katherine and Max for their willingness to discuss my thesis. Thank you to my friends and family who supported me throughout the thesis. Thank you to Jake for bringing me tea and repeatedly explaining commas. Thank you to my parents, and grandparents, for passing down to me a love of gardening and our world. Lastly, I acknowledge the community gardens and gardeners who welcomed me into their space and without whom I would not have had a thesis. 


\begin{abstract}
This thesis responds to the idea that storytelling and gardening are two practices that can be used to re-frame human action within the Anthropocene. Eight gardeners from four community gardens in Wellington City, Aotearoa New Zealand were interviewed. Alongside the interviewees, the author gardened at each of the community gardens from late autumn to early summer 2019. The interviews and field notes have been written up as creative non-fiction essays to form the majority of this thesis. Three major themes are explored through these essays; the patchy Anthropocene (a concept proposed by Anna Lowenhaupt Tsing), the lively multispecies entanglements present at each of the community gardens, and the importance of care.
\end{abstract}




\section{Preface}

This topic brings together my interest in the process and history of gardening, my interest in how storytelling can communicate environmental change, and a desire to familiarise myself more fully with research techniques used in the Environmental Humanities and related fields. I share Pietterette Hondagneu-Sotelo's sentiments: "I love gardens, and I cannot imagine having the self-discipline to research and write on a topic that I do not care about deeply."1 In addition to this research being an enjoyable extension of my previous studies, I believe it is crucial to examine methods of cultivation to determine how we live in (and through) the Anthroprocene.

${ }^{1}$ Pierrette Hondagneu-Sotelo, 'Cultivating Questions for a Sociology of Gardens', Journal of Contemporary Ethnography 39, no. 5 (October 2010): 499, https://doi.org/10.1177/0891241610376069. 


\section{Contents}

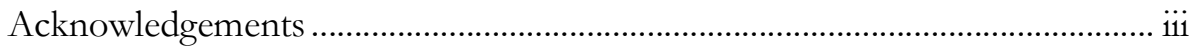

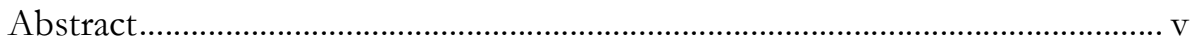

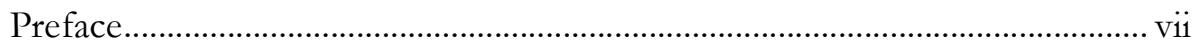

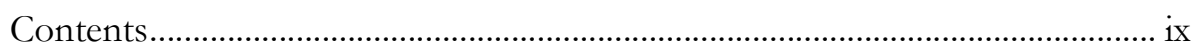

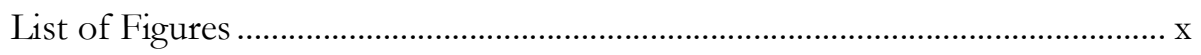

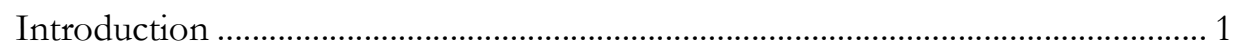

Part 1: Theory and methods............................................................................ 9

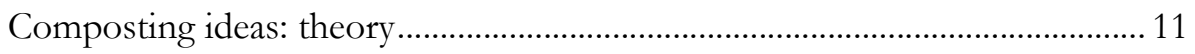

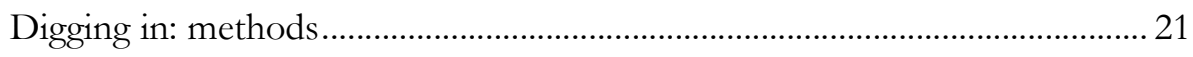

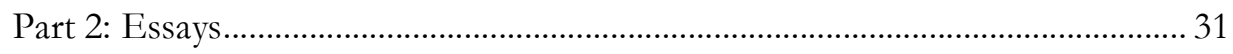

1. Patchworking / Working patches: gardens as blasted landscapes ......... 32

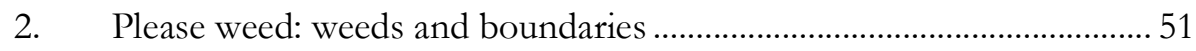

3. Climate and cultivation: generalised systems and local variations ........ 65

4. Say it with beans: growing food and reciprocity...................................... 79

5. Dirt under your fingernails: gardening as care in practice....................... 89

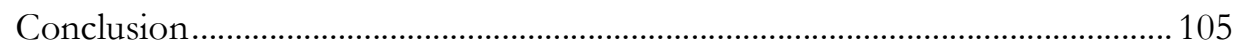

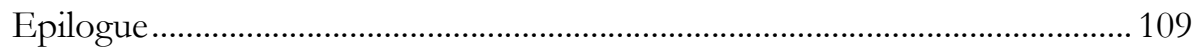

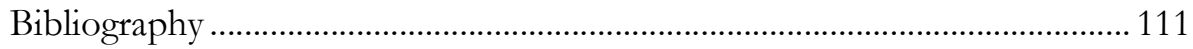




\section{List of Figures}

Figure 1: Map showing locations of the four community gardens. Created

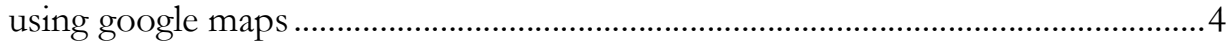

Figure 2: Compost at Innermost Gardens...............................................................11

Figure 3 The sun sets through the Community Orchard.........................................33

Figure 4: An entanglement of plantain and buttercup...........................................52

Figure 5: Gorse in its best light ..........................................................................56

Figure 6: "Please weed" image supplied by Chloe.....................................................61

Figure 7: Miner's lettuce in flower ...................................................................62

Figure 8: Finding food, image supplied by Chloe....................................................79

Figure 9: Sign in the Berhampore Orchard ............................................................ 85

Figure 10: Broad beans in the Khandallah garden .................................................86

Figure 11: Things to pick in Khandallah,. Image supplied by Jenny ....................90

Figure 12 Wendy's allotment in the United Kingdom. image supplied by

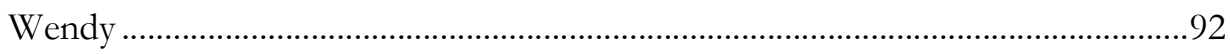

Figure 13: Apple tree in blossom then Community Orchard................................97

Figure 14: M. and a noke, image supplied by Chloe ............................................ 101 


\section{Introduction}

Gardening and storytelling are practices that connect humans to the past, the present, and the future of life on Earth. This thesis explores how gardening and gardens fit into the current period of accelerating environmental change, known, not without controversy, as the Anthropocene. It contains stories gathered and retold through a process of interviews, participation, and observation at four community gardens in Wellington, Aotearoa New Zealand. The resulting essays seek to demonstrate three core concepts: the patches, entanglements, and care. While each theme is present in each of the essays, there is a gradual development throughout the thesis from a focus on patches, to entanglements finally ending on care.

In the last few centuries, human activity has caused significant disruption and damage to Earth's ecological systems. I was interested, when I began this project, in how one aspect of the Anthropocene was present in gardens - climate change. I wanted to know how gardeners thought about the seasons of gardening and about weather, and how they tied this to climate change. What I found was that this narrowing on one aspect of the Anthropocene was unnecessarily limiting. To quote Donna Haraway, "It's more than climate change; it's also extraordinary burdens of toxic chemistry, mining, depletion of lakes and rivers under and above ground, ecosystem simplification, vast genocides of people and other critters..."2

Geologists originally proposed the term Anthropocene as a label for our current epoch, one in which the primary driver of environmental transformation is human activity. The term is contested. In using the term Anthropocene, I take Anna Lowenhaupt Tsing, whose work I draw heavily on, as my guide. She states, "I have stayed with the term Anthropocene despite all this because I see it as still open for concept-changing conversations." 3

The global processes that entangle to form the Anthropocene are both historical and ongoing, and include capitalism, imperialism, colonisation, and the impacts of industrialisation. Tsing states, "We are forced to be ever more aware of the

2 Donna Haraway, 'Anthropocene, Capitalocene, Plantationocene, Chthulucene: Making Kin', Environmental Humanities 6, no. 1 (1 May 2015): 159, https://doi.org/10.1215/22011919-3615934.

${ }^{3}$ Anna Lowenhaupt Tsing, 'Earth Stalked by Man', The Cambridge Journal of Anthropology 34, no. 1 (2016): 13, https://doi.org/10.3167/ca.2016.340102. 
process of finding allies and building collaborations when we realise we are not at the crest of a wave to an imagined better future." "In the face of this disruption, humankind must reconsider what practices still serve us and our companions on this planet.

Tsing uses the label 'patchy Anthropocene' to explore the uneven impact of humankind on the environment. ${ }^{5}$ She argues that our global system is a composite of many local patches; "You cannot 'do' climate change in just one place", yet "None of us live in a global system, we live in places." Tsing goes on to say, "Anthropocene matters because liveability is threatened by the repercussions of human activities. And we experience liveability only through places." ${ }^{, 7}$ I propose that gardens are places where this "liveability" can still be found. They are also fertile ground for exploring different views of time and space by squinting at birds in the sky or digging below the surface.

The theoretical compost for this thesis is heavily influenced by feminists working within the environmental humanities. The work of Jennifer Hamilton and Astrida Neimanis, Donna Haraway, Tsing, alongside others are considered first in "Composting Ideas" and then layered throughout the thesis. Equally important is the ongoing work, and legacy, of indigenous researchers who have shared their stories of ways to think with/be with the Earth. The ideas of Robin Kimmerer, an indigenous and ecological scholar, have been particularly influential. Kimmerer draws from experience in the theoretical world of academia and the material world of gardening. ${ }^{8}$

Thom van Dooren and Deborah Bird Rose, two scholars concerned with more-than-human encounters, write that, "No one - no group or species - ever spins alone." ${ }^{9}$ The multispecies relationships present within each of the community gardens reveal the more-than-buman history of each place. This area of scholarship introduces the concepts of multispecies entanglements and seeks to reimagine possible responses to

\footnotetext{
4 Anna Lowenhaupt Tsing, 'Getting by in Terrifying Times', Dialogues in Human Geography 8, no. 1 (1 March 2018): 75, https://doi.org/10.1177/2043820617738836.

5 Tsing, 'Earth Stalked by Man'.

${ }^{6}$ Tsing. 3.

${ }^{7}$ Tsing, 3 .

${ }^{8}$ Robin Kimmerer, Braiding Sweetgrass: Indigenous Wisdom, Scientific Knowledge and the Teachings of Plants (Minneapolis, United States: Milkweed Editions, 2014).

9 Thom van Dooren and Deborah Bird Rose, 'Lively Ethography Storying Animist Worlds', Environmental Humanities 8, no. 1 (1 May 2016): 85, https://doi.org/10.1215/22011919-3527731.5.
} 
the ecological crises that Earth is facing. Haraway often refers to these issues as "troubles". She takes the word trouble back to its root meanings of "to stir up" or "to disturb". Staying with the trouble asks us (humanity) to be present in these disturbed times, to make trouble by challenging the status quo and settle troubles by creating quiet places. ${ }^{10}$

Storytelling is another practice that has been identified by Haraway, amongst others, as a tool for challenging the Anthropocene. ${ }^{11}$ The majority of this thesis is written with personal observations intertwining with relevant academic literature, natural history and my participants' interviews. The form tests the idea that how and what we write is a method for responding to the Anthropocene. It is not that gardening, or storytelling, will solve these issues, but both provide a position from which we can build the meaningful connection to place and companions we need for survival. $^{12}$

Wellington City has around twenty community gardens within its urban boundary. ${ }^{13}$ Over the course of eight months, I gardened and met gardeners from four of those community gardens; Khandallah Community Garden, Tawa Community Garden, Berhampore Island Bay Community Orchard and Innermost Community Garden on Mt Victoria (Figure 1). Their connections to gardening grounds this work in the material and everyday experience. My garden visits began in late autumn and continued to early summer. During each visit I took rough field notes, observing each garden and my experiences of gardening in them. This fieldwork contributed the material to build the creative non-fiction prose, intermingled with poems and images sourced from these gardens, that makes up the collected essays of Part 2. "Digging In" examines the tools and techniques used as part of my fieldwork and my writing. The choice of community gardens as sites of research is expanded on. My research is qualitative, drawing on the techniques used in oral history, participant observation and field notes.

\footnotetext{
${ }^{10}$ Donna Haraway, Staying with the Trouble: Making Kin in the Chthulucene, Experimental Futures (Durham: Duke University Press, 2016), 1.

${ }^{11}$ Haraway, 31.

12 Marcello Di Paola, 'Gardens and the Anthropocene', in Ethics and Politics of the Built Environment: Gardens of the Anthropocene, ed. Marcello Di Paola, The International Library of Environmental, Agricultural and Food Ethics (Cham: Springer International Publishing, 2017), 1-34, https://doi.org/10.1007/978-3-319-71166-9_1.

13 'Community Gardens', Wellington City Council, accessed 19 February 2019, http://wellington.govt.nz/services/community-and-culture/community-gardens.
} 


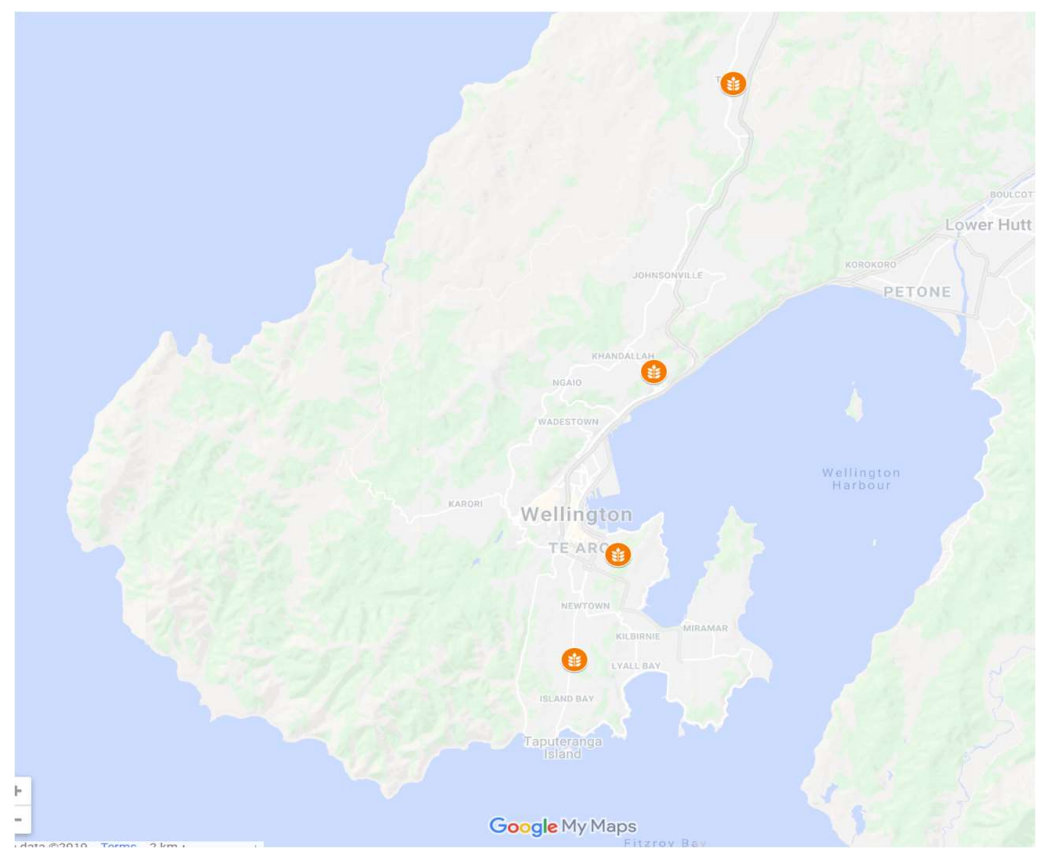

Figure 1: Map showing locations of the four community gardens. Created using google maps

North to Soutb: Tawa Community Garden, Khandallab Community Garden, Innermost Community Garden on Mt

Victoria and Berbampore Island Bay Community Orchard

In "Patchworking / Working patches", I introduce the landscape of

Wellington and the local landscapes of the gardens. This essay examines the ways that human activities and both geological and biological processes leave layers on the landscape. These patches are analysed to demonstrate the connections between local and global processes. The history of each garden is intertwined with wider histories of capitalism, colonisation and modernity. In "Patch 1: Berhampore", the debate about the Anthropocene is summarised before swooping into Holocene entanglements showing how gardens have connections to both epochs. In "Patch 2: Khandallah", the layers of names across the landscape are examined. This shows how colonisation sought to obscure indigenous landscapes through renaming. From colonisation onwards, the trappings of modernity began leaving their mark on Aotearoa. In Khandallah, this is shown by the human infrastructure that prevents the gardeners from digging the soil. In "Patch 3: Tawa", changing ecological entanglements are used to illuminate Haraway's challenge to "stay with the trouble". Her concept of the Chthulucene is highlighted with a squirm of worms taking us below the muddy surface and into tentacular landscapes. ${ }^{14}$ The metaphor of an octopus's garden is a reminder

${ }^{14}$ Haraway, Staying with the Trouble. 
we have a choice between facing our dilemmas or burying our heads. "Patch 4: Innermost Gardens" brings us back to blasted landscapes and the patchy impact of humans on Earth. The impact of DDT and the subsequent remediation through the work of mushrooms show how entanglements can return spaces to patches of liveability. ${ }^{15}$

In "Please weed", humans are shown as drivers of disturbance and dispersers of other species through our entanglements with plants labelled weeds. Weeding is an action undertaken in gardens to benefit some species at the expense of others. Yet definitions of weeds are contested, both within ecology and between gardeners. The idea of "weeds" demonstrates the divergent views among the interviewed gardeners concerning what belongs where and the need to be adaptive in gardening practice. The spread of plantain around the world underlines the role humans play as dispersal agents. Gorse (Ulex europaeus) illustrates the complex interplay between indigenous and introduced species, as well as the futile nature of human enforced borders. ${ }^{16}$ The spread of tradescantia (Tradescantia fluminensis) builds on this while suggesting care is needed in what plants gardeners cultivate. Lastly, the resilience and spread of miner's lettuce demonstrates how humans are part of broader entanglements outside of our control.

The essay "Climate and cultivation" considers how generalised systems, such as climate and monocultures, relate to localised experiences, such as weather and cultivating gardens. The essay has two sections. The first examines how gardeners connect to weather in landscapes and discuss ideas of climate. The second section, through considering human connections with bananas and coffee, compares and contrasts cultivating in plantations and cultivating in gardens. Through the examples of coffee and bananas, it looks at how virulence can flourish in simplified entanglements leading to the loss of our chosen companion species. ${ }^{17}$ The essay argues that the differences between human cultivation techniques come down to care and carefulness.

\footnotetext{
15 Tsing, 'Earth Stalked by Man'.

${ }^{16}$ Michael L.S. Bagge, 'Valuable Ally or Invading Army? The Ambivalence of Gorse in New Zealand, 1835-1900', Australian \& New Zealand Environmental History Network (blog), 19 March 2014, https:/ /www.environmentalhistory-au-nz.org/2014/03/valuable-ally-or-invading-army-theambivalence-of-gorse-in-new-zealand-1835-1900/.

17 Tsing, 'Earth Stalked by Man'.
} 
The four community gardens are all nominally in existence to grow vegetables and fruit for food and in "Say it with broad beans" this comes to the fore. The food that we use to sustain ourselves is political. Our system of food production "is predicated on a global capitalist model that circulates around profit, productivity and efficiency, not around providing equitable access to safe, nutritious and culturally appropriate food." ${ }^{18}$ Here, I collect together the ideas of eating, growing and connections to landscapes. These patches where we cultivate food can also be patches where wider species networks are cultivated. Lindsay Kelley's writing on piñon introduces the idea of both interspecies reciprocity, the plants humans care for so as to be sustained by them, and intraspecies reciprocity, the ways humans can care for each other. ${ }^{19}$ In Aotearoa New Zealand, gardens and landscapes cannot be explored without also considering the impact of colonisation. European colonisation of Aotearoa post1840 led to unprecedented disruptions for both tangata whenua and whenua. The work of Jessica Hutchings on Māori Food Sovereignty adds depth to "Say it with broad beans." ${ }^{20}$ The last section of this essay expands on Kimmerer's call for a reciprocal relationship between gardeners and the Earth. ${ }^{21}$

In "Dirt under your fingernails", I consider how the gardeners care for their gardens. These community gardens cultivate many things beside vegetables, including community and contentment. The rhythmical nature of gardens makes them compelling locations to explore and analyse environmental change. Katie Holmes describes this flux, "The garden is a dynamic space, where change is inevitable and meanings fluid." 22 Over time gardeners come and go, garden beds are built and dismantled, crops are sown and harvested. A constant process of renewal, growth and death takes place. Intergenerational entanglements and cycles of life and death are explored.

${ }_{18}$ Dan Kelly and Jessica Hutchings, 'Sovereignty, Kai, and the Land Where We Grow', Stone Soup, 29 August 2019, https://stonesoupsyndicate.com/features/sovereignty-kai-and-the-land-where-we-grow/.

${ }^{19}$ Lindsay Kelley, 'Plumpiñon', in The Multispecies Salon, ed. Eben Kirksey (Durham: Duke University Press, 2014), 161-75.

${ }^{20}$ Jessica Hutchings, Te Mahi Māra Hua Parakore: A Māori Food Sovereignty Handbook (Ōtaki, Aotearoa New Zealand: Te Tākupu, Te Wānanga o Raukwa, 2015).

${ }^{21}$ Kimmerer, Braiding Sweetgrass, 127.

22 Katie Holmes, 'Gardens', Journal of Australian Studies 23, no. 61 (January 1999): 152-62, https://doi.org/10.1080/14443059909387485. 162 
As individuals and collectives, the ongoing environmental change of the Anthropocene, even in its patchiness, can create a sense of hopelessness. Humankind must reconsider what practices still serve us and our companions on this planet. A garden is an ecosystem composed of multispecies interactions where humans cultivate life and death alongside other species. Gardening allows for action at a manageable scale, in the local patches we are able to access. ${ }^{23}$ This thesis explores this premise by engaging on the ground with gardens and gardeners.

${ }^{23}$ Di Paola, 'Gardens and the Anthropocene'. 1. 
Part 1: Theory and methods 


\section{Composting ideas: theory}

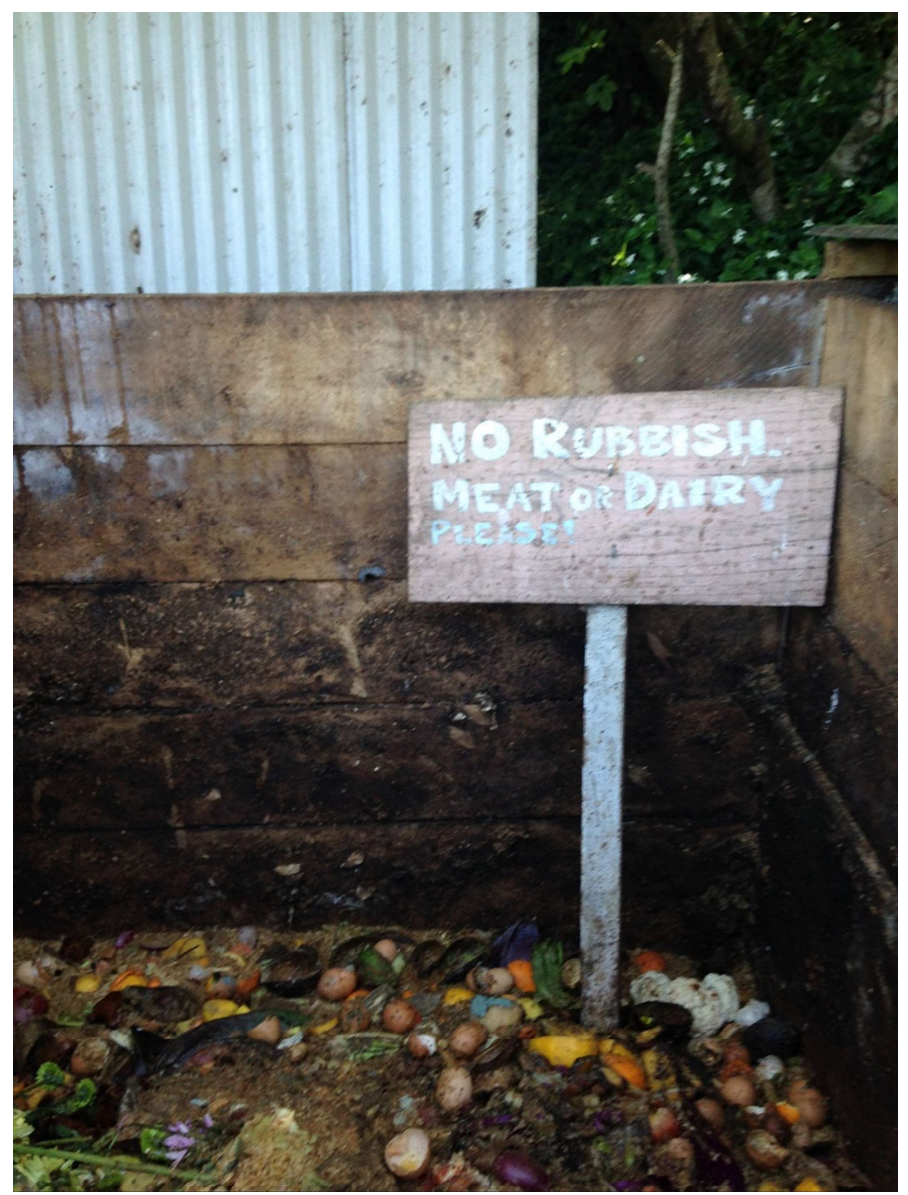

Figure 2: Compost at Innermost Gardens

It matters what compostables make compost.

Jennifer Hamilton and Astrida Neimanis ${ }^{24}$

My introduction to community gardens in Wellington was through composting. I lived in an apartment just off Courtney Place but could not bear to throw out the food scraps. Instead, we gathered them in a bin and, once a month, would slog up the hill to tip about five kilograms of stinky mush into the community compost bins at Innermost Gardens on Mt Victoria. This year I returned to the garden

${ }^{24}$ Jennifer Mae Hamilton and Astrida Neimanis, 'Composting Feminisms and Environmental Humanities', Environmental Humanities 10, no. 2 (1 November 2018): 501, https://doi.org/10.1215/22011919-7156859. 
to find a new compost system, upgraded to deal with the 400 kilograms of food scraps they currently receive approximately every three weeks.

Dropping off the food waste is just the first step. Every working bee, they turn the compost, shovel the contents of the most recent bin into the one next to it and add layers of lime or carbon to balance it out. There are associated tasks; emptying the leachate tank and diluting it to fertilise parts of the garden and transporting 'not quite ready' compost to holding bins. There it can finish off the decomposition process before being applied to the garden. I spent two garden visits gathering wheelbarrows full of green matter to layer into the compost, ideally comfrey - known for the nutrients it harbours in its leaves. I also accompanied Chris, one of the gardeners I interviewed, on a trip to collect bags of macrocarpa sawdust for the carbon layers. What goes into these composts is carefully considered.

I did not get stuck into the compost until my second to last visit. I was handed a shovel, and Chris and I began the process of shovelling from one bin into the other. It was hard work and I was relieved when T., the chief compost carer, took over from me. My replacement task was fetching the sacks of macrocarpa sawdust; layers of this are added to provide the necessary carbon. While Chris and T. shovelled, there was general chat around the content of the compost. This compost receives a high proportion of avocado skins, coffee grinds and citrus - which they hypothesise represents the demographics of the surrounding suburbs. There was also a whole pumpkin which still looked edible, but I was not bold enough to ask for it.

No two compost piles are the same. At Tawa, a three-bin rotation system is carefully maintained with coffee grounds and carbon layered in as needed. In Khandallah, garden waste is added after working bees but these composts are not a spot for the community to drop off food waste. The garden lacks space and gardeners lack the time needed to maintain a compost. At Berhampore, they have a worm bin and several wooden bins: food waste is dropped off from the apartment complex next door and one of the gardeners is responsible for checking that the worms are happy.

In "Composting Feminisms and Environmental Humanities" 25 , Jennifer Hamilton and Astrida Neimanis detail many of the ideas that I have used to guide my research; the power of storytelling to change the world materially, the importance of more-than-human entanglements, the need for intersectional thinking when

${ }^{25}$ Hamilton and Neimanis, 'Composting Feminisms and Environmental Humanities'. 
considering oppressions, and how the personal is political. As they explore these questions, they build compost as a material metaphor and argue that compost making requires care and attention. Here composting becomes figurative and material. My research is built from both the composting layers of others' text and the messy business of gardening, and I am attempting to write, in the words of Hamilton and Neimanis, "the world-to-come with soil-stained fingers." 26

Hamilton and Neimanis put forward a challenge: How have feminist concepts and ideas been used as foundational material inside the environmental humanities? In response to this provocation, I consider carefully the origin of ideas that have formed my theoretical compost. The well-established feminist thinkers Tsing and Haraway are an influential part of my compost. Tsing's ongoing consideration of the patchy Anthropocene forms the bedrock overlaid with Haraway's call for us to stay with the trouble. ${ }^{27}$ Tsing refers back to Marilyn Strathern's idea of the muddle, a helpful frame to consider in relation to the gardens and the tensions between control versus care, "She asks us to patiently sit in a muddle, not trying to solve it, but to take the time to consider incommensurability." 28

Inside the academy, citations remain an important factor in uplifting certain voices. Where possible, I have practised the "politics of citation" as put forward by Sara Ahmed, ${ }^{29}$ and others, as a way of "deliberately and carefully" ${ }^{30}$ considering whose ideas are being used in my compost. In feminist theory, the idea of perspectives is of utmost importance and explored from many angles. Hamilton and Neimanis draw on Adrienne Rich's idea that "we are also many, and do not want to be the same." 31

Part of gardening is learning that not all soil is the same. The process of composting is about making soil that can sustain life. To take it one step further: with compost you make soil and with soil you make landscapes. Jessica Hutchings, Jo Smith and Garth Harmsworth have proposed a framework for the soil of Aotearoa based on mātauranga Māori. “Accordingly, a handful of soil, from a Māori-values point of view,

\footnotetext{
${ }^{26}$ Hamilton and Neimanis, 88.

${ }^{27}$ Haraway, Staying with the Trouble.

${ }^{28}$ Tsing, 'Earth Stalked by Man', 4-5.

${ }^{29}$ Sara Ahmed, 'Making Feminist Points', Feministkilljoys (blog), 11 September 2013, https:// feministkilljoys.com/2013/09/11/making-feminist-points/.

${ }^{30}$ Hamilton and Neimanis, 'Composting Feminisms and Environmental Humanities', 517.

${ }^{31}$ Hamilton and Neimanis, 512.
} 
embodies a complex whakapapa of relationships with mutually sustaining obligations." ${ }^{32}$ In other words a relationship of reciprocity. As a settler colony of the British Empire, the wars for sovereignty in Aotearoa were played out over land. ${ }^{33}$ The cost of colonisation for tangata whenua was the immeasurable loss of their whenua. My thesis considers this backdrop to these garden stories.

As a Pākehā gathering stories from gardens that are not explicitly Kaupapa Māori, I am mindful of recognising this history without co-opting it. Hamilton and Neimanis' words reflect that as white settlers on indigenous lands, "We are bound to be clumsy. This is all the more reason to take care." ${ }^{34}$ In careful response to this I have attempted to draw on Māori sources deliberately. Where an overseas indigenous use is listed for a plant companion in one of my gardens, I have where possible used a source from within that indigenous culture. The repetition of indigenous knowledge without citation is a form of erasure and continuation of the colonisation of knowledge. ${ }^{35}$

This planet teems with species in constant conversations with each other; plants, animals, microbes - relationships often referred to as entanglements. ${ }^{36}$ One branch of the environmental humanities seeks to explore these relationships under the term multispecies. Tsing challenges us to consider which species we will ally ourselves with in the patchy Anthropocene. ${ }^{37}$ A garden is particularly fertile ground for examining these multispecies relationships - to co-opt Tom Dooren and Deborah Rose's words above, no group or species ever gardens alone. Van Dooren and his colleagues describe the approach as looking at "the multitudes of lively agents that bring one another into being through entangled relations that include, but always also exceed, dynamics of predator and prey, parasite and host, researcher and researched,

\footnotetext{
${ }^{32}$ Jessica Hutchings, Jo Smith, and Garth Harmsworth, 'Elevating the Mana of Soil through the Hua Parakore Framework', MAI Journal: A New Zealand Journal of Indigenous Scholarship, 2018, 94, https://doi.org/10.20507/MAIJournal.2018.7.1.8.

${ }^{33}$ Rachel Buchanan, 'Beating Shame: Parihaka and the Very Long Sorry', Te Pouhere Korero Māori History, Mãori People 6 (2012): 55-82.

${ }^{34}$ Hamilton and Neimanis, 'Composting Feminisms and Environmental Humanities', 521.

${ }^{35}$ Linda Tuhiwai Smith, Decolonizing Methodologies: Research and Indigenous Peoples, 2nd ed. (London ; New York: Zed Books, 2012), 121.

${ }^{36}$ Elaine Gan et al., 'Introduction: Haunted Landscapes of the Anthropocene', in Arts of Living on a Damaged Planet, ed. Elaine Gan et al., Ghosts and Monsters of the Anthropocene (University of Minnesota Press, 2017), G2.

${ }^{37}$ Tsing, 'Getting by in Terrifying Times', 75.
} 
symbiotic partner, or indifferent neighbor (sic)." ${ }^{38}$ Entanglements could be referred to as ecosystems, mutualisms, parasitism, or a multitude of other terms depending on the context. Here the term entanglements represents the complexities of interactions that occur between species. While the non-fiction essays in this thesis draw on the work of ecologists and biologists, the theoretical underpinnings are not from these disciplines. The use of language from the environmental humanities is a deliberate positioning within that branch of knowledge.

Thom van Dooren, Eben Kirksey, and Ursula Münster explain Karen Barad’s theory of agential realism as that "while tables, atoms, and cauliflowers are very much real, they are also shaped by modes of understanding and engagement" 39 To take the cauliflower, as an appropriately garden-based example, the question is not whether it exists but the multiple ways it might be described. Mine might also be different depending on the day, whether I've planted cauliflowers recently (I'd describe the seedling), whether I've had cauliflowers fail in my garden (I'd describe the caterpillars), whether I am hungry (I'd describe how best to cook cauliflowers).

Here multispecies studies meet feminist discourse. Hamilton and Neimanis discuss the important overlap with the "more-than-human" stories of multispecies studies. "Bodies (our own, and those of more-than-human others) are understood as permeable and interdependent." ${ }^{40}$ Permeable and interdependent are both terms that can be explored in relation to community gardens too, in particular they come to the fore in the relationship between gardeners and weeds in "Please weed".

Inside multispecies studies, ideas of "we" and voice are discussed, with concern over who is speaking for who. The hope is to achieve a view of the world where all lively beings become "dynamic subjects" rather than objects waiting for our action. ${ }^{41}$ One method for addressing this is through storytelling. In the words of Thom van Dooren and Deborah Bird Rose, "a story can allow multiple meanings to travel

\footnotetext{
38 Thom van Dooren, Eben Kirksey, and Ursula Münster, 'Multispecies Studies Cultivating Arts of Attentiveness', Environmental Humanities 8, no. 1 (1 May 2016): 1-23, https://doi.org/10.1215/22011919-3527695. 3

${ }^{39}$ van Dooren, Kirksey, and Münster, 12.

${ }^{40}$ Hamilton and Neimanis, 'Composting Feminisms and Environmental Humanities', 519.

${ }^{41}$ Anna Lowenhaupt Tsing, 'Dancing the Mushroom Forest', PAN: Philosophy Activism Nature, no. 10 (2013): 13 .
} 
alongside one another; it can hold open possibilities and interpretations and can refuse the kind of closure that prevents others from speaking or becoming." ${ }^{42}$

Stories and storytelling form a method of resistance to the dominant narratives that have driven the Anthropocene. They become a way to allow different perspectives to travel alongside one another. ${ }^{43}$ Hamilton and Neimanis go further to state, "Telling certain stories is about changing the world in specific, material ways." ${ }^{44}$ So, which stories do we tell in a world that is both crumbling, combusting, and growing in patchy measures? There is a lot of scholarship on the power of stories. However, I believe the first word on the matter should be given to those who weave the stories, the storytellers themselves.

Storytelling has sustained indigenous ways of knowing, despite colonisers' attempts to control the narrative. ${ }^{45}$ In Baby No Eyes Patricia Grace (Ngati Toa, Ngati Raukawa and Te Ati Awa) writes of a way of storytelling.

There is a way the older people have of telling a story. A way where the beginning is not the beginning, the end is not the end. It starts from the centre and moves away from there in such widening circles that you don't know how you will finally arrive at a point of understanding, which becomes itself another core, a new centre. ${ }^{46}$

Grace's story weaves through generations, through the way seemingly disparate events have links. These are the stories of people, not heroes. This is very similar to my reading of Ursula Le Guin's idea of the "life story" suggested in "The carrier bag theory of fiction.” Le Guin talks about how life stories have been subsumed by the hero narrative. She proposes we turn away from Hero narrative, or the "killer story", instead looking to tell our "life story". ${ }^{47}$ The hero story obscures that "what we actually did to stay alive and fat was gather seeds, roots, sprouts, shoots, leaves, nuts, berries, fruits, and grains..."48

\footnotetext{
42 van Dooren and Rose, 'Lively Ethography Storying Animist Worlds', 85.

43 van Dooren, Kirksey, and Münster, 'Multispecies Studies Cultivating Arts of Attentiveness', 9.

${ }^{44}$ Hamilton and Neimanis, 'Composting Feminisms and Environmental Humanities', 516.

${ }^{45}$ Hamilton and Neimanis, 514-15.

46 Patricia Grace, Baby No-Eyes (Auckland, N.Z: Penguin Books, 1998), 28.

${ }^{47}$ Ursula K. Le Guin, 'The Carrier Bag Theory of Fiction', in Dancing at the Edge of the World: Thoughts on Words, Women, Places, 1st ed. (New York: Grove Press, 1989), 168.

${ }^{48}$ Le Guin, 165.
} 
Le Guin is frequently cited as inspiration for those looking to tell stories fit for the Anthropocene. ${ }^{49}$ Le Guin's call, to tell the life stories of people and our companions and stop relying on heroes, is more relevant than ever. We are living in an age where there are no heroes to save us from the monsters and ghosts the haunt the Anthropocene..$^{50}$

Storytelling about our environment is not new but it has been embraced as a technique by those exploring the ideas and issues raised by the Anthropocene. Arts of living on a damaged planet, edited by Elaine Gan, Anna Lowenhaupt Tsing, Heather Anne Swanson, and Nils Bubandt, is one example of how storytelling is being harnessed in this regard; it forms two collections of essays brought together on the themes of ghosts and monsters. ${ }^{51}$ In "Coda", one of these essay, Mary Louise Pratt brings into the light how ideas of narrative theory are being employed in these collections. Pratt states, "the raw material for writing is other writing." 52 In this thesis the raw material has been drawn from others' writing, others' words and others' gardens.

My third important theme, after patches and entanglements, is that of care. Bird Rose's work on more-than-human encounters and the ethics of decolonisation adds an important layer to this. Bird Rose argues that it is important not to forget the violence humans are capable of.$^{53}$ Core to the idea of life stories is the idea of care and reciprocity, looking beyond the violence and seeing what other ways of being exist.

Holly Buck, an interdisciplinary scholar who writes on ethics in the Anthropocene, suggests that "The garden is a site through which we can examine connection and care in practice." 54 The links between gardening, ethics and the Anthropocene are perhaps most explicitly explored by Marcello Di Paola in his book

49 Anna Lowenhaupt Tsing, The Mushroom at the End of the World: On the Possibility of Life in Capitalist Ruins (Princeton, United States: Princeton University Press, 2015), 287.

${ }^{50}$ Elaine Gan et al., Arts of Living on a Damaged Planet: Ghosts of the Anthropocene (Minneapolis: University of Minnesota Press, 2017).

51 Gan et al.

52 Mary Louise Pratt, 'CODA:: CONCEPT AND CHRONOTOPE', in Arts of Living on a Damaged Planet, ed. Anna Tsing et al., Ghosts and Monsters of the Anthropocene (University of Minnesota Press, 2017), G172, www.jstor.org/stable/10.5749/j.ctt1qft070.14.

${ }^{53}$ Deborah Bird Rose, 'Shimmer: When All You Love Is Being Trashed', in Arts of Living on a Damaged Planet, ed. Elaine Gan et al., Ghosts and Monsters of the Anthropocene (University of Minnesota Press, 2017), 51-63, www.jstor.org/stable/10.5749/j.ctt1qft070.7.

${ }^{54}$ Holly Jean Buck, 'On the Possibilities of a Charming Anthropocene', Annals of the Association of American Geographers 105, no. 2 (4 March 2015): 374, https://doi.org/10.1080/00045608.2014.973005. 4. 
Ethics and Politics of the Built Environment Gardens of the Anthropocene. ${ }^{55}$ The book argues that urban gardening, of almost any form, is a practice that will serve humanity well in the Anthropocene. This thesis is a partial response to the idea, taking the provocation and going out into the gardens to more personally understand what gardening in the Anthropocene means.

I have interpreted reciprocity, and ideas of reciprocal capture, ${ }^{56}$ as a component of care. Kimmerer's writing on our relationship to the Earth has been influential here. Kimmerer is a member of the Citizen Potawatomi Nation (Oklahoma) and an ecologist trained in the western tradition working at the State University of New York. She combines these two knowledge systems in her book Braiding Sweetgrass along with her with love of gardening. It is a compelling account of reciprocal capture between more-than-species entanglements. Kimmerer examines the relationship between humans and the land, "how we are given so much and what we might give back." ${ }^{57}$

Sandra Laugier's suggests that care requires action and is quite an ordinary undertaking. Laugier writes "The notion of care is best expressed not in the form of a theory, but an activity: for example, care as action (taking care/ caring for) and as attention or concern (care about)." ${ }^{58}$ It is also something that takes work, and practical decision making. It reminds me of Le Guin's description of gathering seeds and nuts to stay alive.

It is appropriate to end with Maria Puig de la Bellacasa as her work brings the ethics of care to bear on soil-human relations. She considers the creation of soil an act that happens on multiple timescales, with more-than-human involvement, from epochs to the creation of compost. ${ }^{59}$ We need to take better care of the landscapes we live in and the soil that sustains us. One possibility for that is making compost. The idea of care as action motivated me to see what happens if you actually go out into the gardens. It is not enough to just compost ideas, you have to do the actual composting.

\footnotetext{
55 Di Paola, 'Gardens and the Anthropocene'.

${ }^{56}$ Kelley, 'Plumpiñon'.

${ }^{57}$ Kimmerer, Braiding Sweetgrass, 122.

58 Sandra Laugier, 'Politics of Vulnerability and Responsibility for Ordinary Others', Critical Horizons 17, no. 2 (May 2016): 211.

${ }^{59}$ Maria Puig de la Bellacasa, 'Making Time for Soil: Technoscientific Futurity and the Pace of Care', Social Studies of Science 45, no. 5 (1 October 2015): 691-92, https://doi.org/10.1177/0306312715599851.
} 
Notes from the author

Who is writing

this garden?

One person

scrawled

a poem on it

someone else

edited it

with red pen

a toddler

made some additions

with a crayon.

Later a dog

chewed off a corner

Then a blackbird

pecked out

the new seedlings

and finally,

a flood killed

all the lettuces. 


\section{Digging in: methods}

One definition of the Environmental Humanities is "interdisciplinary scholarship that draws humanities disciplines into conversation with each other, and with the natural and social sciences, around significant environmental issues." ${ }^{90}$ The field of Environmental Humanities "necessitate the creation of new approaches that draw different methods and literatures into dialogue around shared matters of concern. ${ }^{\prime 61}$ As such my methods have drawn from a variety of disciplines.

I began with a broad research question to allow scope for the research to develop and respond to my interviews. From interviews, I wanted to elicit personal observations of changes in local climates and growing conditions. I spoke to gardeners active in community gardens about their experiences of gardening, their perceptions of weather and climate, and what understanding they have of possible impacts of climate change in the Wellington region. The interviews were wide ranging and were led by the specific concerns and experiences of the interviewees. The aim was to gather perceptions and stories using qualitative methods. Alongside the interviews, I participated in gardening alongside the gardeners. Equipped with interviews, and field notes, I sorted them into themes and began the process of weaving stories from the content.

Site selection: community gardens

In the words of Katie Holmes, the Australian Environmental Historian, in a garden "we can find rich layers of meaning which suggest other ideas and conflicts implanted there, and which need only a little digging to uncover." ${ }^{\prime 62}$ I chose to focus on community gardens due to their position between public and private spaces. Garden and environmental historian Andrea Gaynor introduces the dynamic between independence and interdependence. A private garden is conceptually a place to

\footnotetext{
60 “Environmental Humanities," Journal of Environmental Humanities, accessed 12 March, 2019, http://environmentalhumanities.org/.

${ }^{61}$ Emily O'Gorman et al., 'Teaching the Environmental Humanities International Perspectives and Practices', Environmental Humanities 11, no. 2 (1 November 2019): 427-60, https://doi.org/10.1215/22011919-7754545.

62 Holmes, 'Gardens'.
} 
encourage independence. ${ }^{63}$ In contrast, a community garden encourages collective support structures and interdependence. ${ }^{64}$ While many community gardens have ideals of complete interdependence, there is often a hybrid of the two. Some community gardens sit behind locked gates. Some have conditions about who can harvest, while others view themselves as an open pantry, with all produce going free to a 'good home'. No two community gardens are identical. Wellington City Council's definition of a community garden is, "a small-scale, low-investment neighbourhood communal gardening venture, where the primary purpose is growing vegetables or fruit." ${ }^{\prime 5}$

My focus on Wellington-based community gardens is purposive sampling. ${ }^{66} \mathrm{I}$ knew I wanted to talk to gardeners and be involved in community gardens, and therefore identified the gardens and community gardeners that were accessible to me. The four sites for this study were found by emailing the public contact information for community gardens operating in the Wellington region. ${ }^{67}$ Originally, I was interested in community gardens in the wider region (Kapiti, Hutt Valley, Wairarapa), but time and costs associated with transport meant tightening the focus. I made an initial approach to the eighteen community gardens listed as operating and had responses from seven. Five indicated interest, one stated they were too busy to participate, and one stated they were currently inactive. In determining which four to select I considered geographic spread, and the four sites span the length of Wellington from the edge of Island Bay in the south to Tawa in the north (Figure 1).

The four sites are:

- Khandallah Community Garden, Corner of Mandalay Terrace and Onslow Road, Khandallah, established 2014 on road reserve, $440 \mathrm{~m}^{2}$

- Tawa Community Garden, Coronation Park, Tawa, established on front section of public park, $480 \mathrm{~m}^{2}$

\footnotetext{
${ }^{63}$ Examples of relevant scholarship into these dynamics and differences are explored in Nick Rose and Andrea Gaynor's Reclaiming the Urban Commons: The Past, Present and Future of Food Growing in Australian Towns and Cities.

${ }^{64}$ Andrea Gaynor, Harvest of the Suburbs: An Environmental History of Growing Food in Australian Cities / Andrea Gaynor. (Crawley, W. A.: University of Western Australia Press, 2006), 194-95.

65 Wellington City Council, 'Wellington City Council Guidelines for Community Gardens', Community Gardens, n.d., 9 .

${ }^{66}$ H. Russell Bernard, Research Methods in Anthropology: Qualitative and Quantitative Approaches / H. Russell Bernard., Sixth edition.. (Lanham, Maryland: Rowman \& Littlefield, 2018), 147, https://ebookcentral.proquest.com/lib/vuw/detail.action?docID=5113478.

67 “Community gardens," Wellington City Council, accessed 17 March, https://wellington.govt.nz/services/community-and-culture/community-gardens/contacts
} 
- Innermost Gardens, Lawson Place, Mt Victoria, established 2006 on former Bowling Club land owned by WCC, $2884 \mathrm{~m}^{2}$

- Island Bay and Berhampore Community Orchard, Adelaide Road, Island Bay/Berhampore, established 2011, $1773 \mathrm{~m}^{2}$

All these sites are located on council-owned land leased to the gardening communities. They operate under variations of common garden plots, with Innermost Gardens including a section devoted to individual allotments. Each has a different approach to harvest rights. Khandallah and Tawa are open pantries - anyone from the community is free to harvest from them. Innermost and Berhampore ask that you contribute to the garden in some way. I did not deliberately exclude community gardens operating only with plot-based gardens but, in the end, none of those groups responded.

Participant selection: gardeners

I used a nonprobability sampling method to find gardeners to interview. ${ }^{68}$ The most important selection category was that participants were willing to share their stories. In my contact to the community gardens, I asked for suggestions of active community gardeners who would be happy to be interviewed. The recruitment process was slightly different for each garden. At Berhampore the chair contacted other members of the group and arranged times for me to meet with them. At Tawa my email was circulated, and gardeners were told to get directly back in touch with me. At Innermost Gardens and Khandallah, it was suggested I come to a working bee and then explain my project in person; after that process the gardeners interested in participating approached me.

I based the decision of who to interview on their willingness to talk to me, with the condition that they were actively involved in the community garden. While it was not a requirement, all were also involved in an organisational aspect of the site. The length of time individuals had been involved greatly varied, from a number of years to a number of weeks. I had originally indicated that I would consider age, gender, and race; however, the number of individuals interested in being interviewed

\footnotetext{
${ }^{68}$ Bernard, Research Methods in Anthropology.
} 
was too small to allow me to be selective in this regard. All my participants presented as female and of European descent. I did not collect demographic information on my participants. Eight gardeners from four gardens became my core participants.

- Alison - Tawa Community Garden

- Cathy - Berhampore Island Bay Community Orchard

- Chloe - Berhampore Island Bay Community Orchard

- Chris - Innermost Gardens

- Jan - Berhampore Island Bay Community Orchard

- Jenny - Khandallah Community Garden

- Kate - Khandallah Community Garden

- Wendy - Innermost Gardens

Participant selection: companion species

The community garden sites are packed with multispecies entanglements. Selecting which of these to highlight was led by the interview and participant observation process. The various species that take their place in the resulting essays were either mentioned by the gardener or present during my participant observation time in the garden. I endeavour to position them as subjects, living parts of the garden.

Interviews

Interview techniques were largely drawn from oral and environmental history. Telling Environmental Histories: Intersections of Memory, Narrative and Environment edited by Katie Holmes and Heather Goodall informed my development of interview techniques. In the words of Holmes and Goodall, "Oral history grounds abstract ideas about place by locating the memory of particular experiences in particular places."

${ }^{69}$ Katie Holmes and Heather Goodall, 'Introduction: Telling Environmental Histories', in Telling Environmental Histories: Intersections of Memory, Narrative and Environment, ed. Katie Holmes and Heather Goodall, Palgrave Studies in World Environmental History (Cham: Springer International Publishing, 2017), 5, https://doi.org/10.1007/978-3-319-63772-3_1. 
Our daily landscapes are often an overlooked part of our lives, the knack to these interviews is to remind participants of the environments they engage with regularly. ${ }^{70}$

In general, the advice is to ask interviewees to describe their activities, then directly question how they feel about these activities. Asking questions about interactions with their environment can create space for nuances to be discussed. Goodall advises that the first question should be about their life story as, "in doing so, they inadvertently reveal how their lives have been embedded within environments." 71 In this way, I started each interview by asking them their earliest memory of gardens or who else in their family gardened. That question then became a base point from which to explore their experience of gardening and their current community garden.

Climate change is a particular aspect of the Anthropocene I wanted to explore in these gardens. Studies of climate and how it is changing have tended towards quantitative methods within the sciences. ${ }^{72}$ However, as well as a physical phenomenon, climate is a cultural phenomenon. ${ }^{73}$ Understanding climate culturally means understanding weather-cultures in situated locations. In each of my conversations with the gardeners, we talked about the weather, seasons, and their thoughts, if any, on climate change. The weather is the first rung on the ladder of abstraction to climate, but it is an important one. Eliza de Vet puts forward the idea that "climate change will be experienced through daily changes in weather patterns, including wind, rain, storms, humidity, and cloud cover." ${ }^{74}$ De Vet challenges us to look at how people engage everyday with weather (weather-relations) and respond as needed.

\footnotetext{
${ }^{70}$ Heather Goodall, 'Rivers, Memory and Migrancy: Everyday Place-Making in Changing Environments', in Telling Environmental Histories: Intersections of Memory, Narrative and Environment, ed. Katie Holmes and Heather Goodall, Palgrave Studies in World Environmental History (Cham: Springer International Publishing, 2017), 31, https://doi.org/10.1007/978-3-319-63772-3_2.

${ }^{71}$ Goodall, 32.

72 Eliza de Vet, 'Exploring Weather-Related Experiences and Practices: Examining Methodological Approaches', Area 45, no. 2 (1 June 2013): 198-206, https://doi.org/10.1111/area.12019.

${ }^{73}$ Mike Hulme, Weathered: Cultures of Climate (London, UNITED KINGDOM: SAGE Publications, 2016).

${ }^{74}$ Eliza de Vet, 'Experiencing and Responding to Everyday Weather in Darwin, Australia: The Important Role of Tolerance', Weather, Climate, and Society; Boston 9, no. 2 (April 2017): 141-54, http://dx.doi.org/10.1175/WCAS-D-15-0069.1. 2017, 142.
} 
Anderson writes that "the act of retelling is a critical narrative act, for stories reflect current understanding through their retelling." ${ }^{75} \mathrm{My}$ interviews revealed different perceptions about environmental change in Aotearoa. Regardless of whether we can already perceive the impacts of climate change, the perception that we can is of cultural significance and reveals current understandings.

In the period between my first round of interviews and the second, I completed an intensive course on Oral History technique. Anna Green and Megan Hutching, the historians leading this course, advised against transcription of whole recordings, instead suggesting thorough indexing. I listened to each interview in full and, as I went, I made notes on themes and indexed the interview. Quoted material was transcribed directly into the manuscript. This technique reduced time spent in transcribing content that may be not directly quoted.

Fieldwork

My garden visits stretched from late autumn to early summer. When I began, the leaves were beginning to fall off the orchard trees and, when I finished, there were small fruits appearing from pollinated buds. The purpose of visiting the gardens across the year was to see this, the changes in the garden landscape across the seasons and experience the garden alongside the gardeners. I developed an observation schema based on Lorena Gibson's work including space for noting down the sounds and smells of each location. ${ }^{76}$ In general, I followed this rule of thumb from $\mathrm{H}$ Russell Bernard, "If something in your environment makes a strong sensory impression, write it down." 77

I engaged in activities at each community garden alongside the participants. Di Paola states, "Whatever else is true, a garden is a place where gardening is done; and one primary way to experience a garden is by gardening it." ${ }^{78}$ By gardening alongside my participants, I could more fully experience each of the garden sites. In addition, it

\footnotetext{
${ }^{75}$ Deb Anderson, 'Hearing the Legacy in the Forecast: Living with Stories of the Australian Climate', in Telling Environmental Histories: Intersections of Memory, Narrative and Environment, ed. Katie Holmes and Heather Goodall, Palgrave Studies in World Environmental History (Cham: Springer International Publishing, 2017), 282, https://doi.org/10.1007/978-3-319-63772-3_11.

${ }^{76}$ Lorena Gibson, 'A Template for Writing Fieldnotes', Anthropod (blog), 14 August 2013, https://anthropod.net/2013/08/14/a-template-for-writing-fieldnotes/.

${ }^{77}$ Bernard, Research Methods in Anthropology, 286.

${ }^{78}$ Di Paola, 'Gardens and the Anthropocene', 6.6
} 
opened up the conversations in ways beyond what was achievable in a strict interview setting. I was both able to demonstrate that I knew and valued gardening, that I was more than a neutral outsider, but also that I was open to learning about their space and be led by them. Through the working bees, I built rapport with the gardeners and through that rapport the conversations we had opened up. ${ }^{79}$

Hondagneu-Sotelo writes "gardens are fundamentally visual experiences" $" 80$ and in response I felt it was important that a portion of my methods included collecting visual material. I took photos as part of my observations and have used them throughout the essays where they illustrate part of the narrative. Garden maps were drawn by me or provided by the gardeners.

Participants were asked to provide photos that indicated something of significance to them in the garden. This visual aspect forms only a small part of the method I used. Where photos were provided, they are discussed at appropriate points in the essays. The technique of asking for an object or image is frequently used in oral history as a way to elicit responses. ${ }^{81}$ It was also a small way for the gardeners to illustrate what makes the garden important to them directly, without their thoughts being filtered through my words. ${ }^{82}$

Rachel Buchanan (Taranaki, Te Atiawa), a New Zealand historian, challenges researchers to consider 'If you are taking the bread from people's mouths' in your research - and aren't we all in some way - then what kind of sustenance are you offering in return?" ${ }^{23}$ My participation in the gardens was a crucial component for me. Not only did it open up the conservations, it enabled me to contribute back to the space I was gathering stories from. Be it weeding, planting seeds or shovelling compost, I actively participated in garden activities and made small, but material, contributions to each community garden.

${ }^{79}$ Bernard, Research Methods in Anthropology, 293.

${ }^{80}$ Hondagneu-Sotelo, 'Cultivating Questions for a Sociology of Gardens', 505.

${ }^{81}$ Anderson, 'Hearing the Legacy in the Forecast'.

82 Sarah Pink, Doing Visual Ethnography (1 Oliver's Yard, 55 City Road, London England EC1Y 1SP United Kingdom: SAGE Publications, Ltd, 2007), https://doi.org/10.4135/9780857025029.

${ }^{83}$ Rachel Buchanan and Maria Tumarkin, 'Bread and Breath: Two Reflections on the Ethics of (Doing) History', Australian Humanities Review, no. 52 (May 2012). 


\section{Writing}

In "Composting ideas", I discuss the importance of storytelling as part of facing the Anthropocene. Here I consider in slightly more detail the method of telling these stories. The creative non-fiction essays have a narrative that includes my personal reflection, perspectives from the interviewed gardeners, and exploration of the other species present in the garden. Research is intertwined with personal reflection (both my own and others) and descriptive elements. Additionally, natural history information and ecological observation are included where appropriate.

Thomas J. Lyon, in "A Taxonomy of Nature Writing", ${ }^{84}$ suggests the ramble as one way of writing about nature. To bring back the ideas of Grace and Le Guin, this style of writing means allowing meandering rather than a simple narrative where the hero triumphs over adversity. It means accepting that some stories have no simple beginning and end.

In a ramble, "the natural history and the author's presence are more or less balanced". ${ }^{85}$ Here, the author is both an observer and participant in nature, most often in movement in a location near their place of living. Rambles give space for weaving in humans, weather, history and more. Lyon suggests that "deep familiarity with the most ordinary landscapes can blossom into immense themes." This idea has been used in both how I undertook my fieldwork -gardening after all cannot be done by standing still - how I conducted my interviews, embracing the rambling stories as told to me, and how I have constructed the thesis, embracing the movement of myself, my participants (both human and more-than-human), the seasons and the weather inside the essays.

As discussed in "Composting ideas", perspectives from a feminist scholar viewpoint are very important. ${ }^{86}$ They come further to the fore when writing. The perspectives that I've gathered are from gardeners in gardens. I'm telling stories of a place from a place. Someone digging in the same place would find a whole different story to tell. I have thought carefully about voice and perspectives. I did, for example

\footnotetext{
84 Thomas J. Lyon, 'A Taxonomy of Nature Writing', in The Ecocritism Reader (Athens, Georgia: University of Georgia Press, 1996), 276-80.

${ }^{85}$ Lyon, 277.

${ }^{86}$ Hamilton and Neimanis, 'Composting Feminisms and Environmental Humanities', 504.
} 
experiment with writing in the third person. This has been used in some

Environmental Humanities work to draw attention to the person without identifying in the first person. ${ }^{87} \mathrm{I}$ decided against this technique as the result seemed to distant myself and others from the garden, when I was trying to bring a closeness to the subject at hand.

Dispersed throughout the thesis and the essays are poems. Le Guin writes of how poems and science can offer different ways of speaking with the world:

Poetry is the human language that can try to say what a tree or a rock or a river $i s$, that is, to speak humanly for it, in both senses of the word "for." A poem can do so by relating the quality of an individual human relationship to a thing, a rock or river or tree, or simply by describing the thing as truthfully as possible. ${ }^{88}$

My poems are an attempt to allow the landscapes and entanglements to speak in another way. A way with slightly less filters and slightly more feeling. In some cases, they are found poems, written directly drawing on the quotes of my participants. This, if applicable, is indicated by footnotes.

\section{Summary}

My research has drawn on a variety of methods from across disciplinary boundaries. My site and participant selection used non-probability sampling, using convenience and willingness to engage as determining factors. The more-than-human companions that have become subjects of the following essays were those that cropped up in interviews and during gardening. The interviews draw on oral and environmental history techniques, and the field work was grounded in the practices of participant observation. The writing brings it all together in creative non-fiction essays interspersed with poems and photos of the gardens. By using creative non-fiction essays to write my thesis, I seek to demonstrate that relevance of storytelling in practice.

${ }^{87}$ Lesley Instone and Affrica Taylor, 'Thinking About Inheritance Through the Figure of the Anthropocene, from the Antipodes and in the Presence of Others', Environmental Humanities 7, no. 1 (1 May 2016): 133-50, https://doi.org/10.1215/22011919-3616371.

${ }^{88}$ Ursula K. Le Guin, 'DEEP IN ADMIRATION', in Arts of Living on a Damaged Planet, ed. Anna Tsing et al., Ghosts and Monsters of the Anthropocene (University of Minnesota Press, 2017), M16, https://www.jstor.org/stable/10.5749/j.ctt1qft070.19. 
Part 2: Essays 


\title{
1. Patchworking / Working patches: gardens as blasted landscapes
}

I consider community gardens as patches on a landscape showing overlaid arrangements between the human and the nonhuman, the biotic and the abiotic. Each patch has its own history, making them distinct patches on the same patchwork. To understand the landscape requires looking back before we look forward.

\author{
patches \\ This story is \\ made of patches \\ of garden. \\ These gardens \\ are made of \\ patches of earth. \\ This story is \\ made of earth. \\ This earth \\ requires work.
}


Patch one: Community Orchard Berhampore and Island Bay

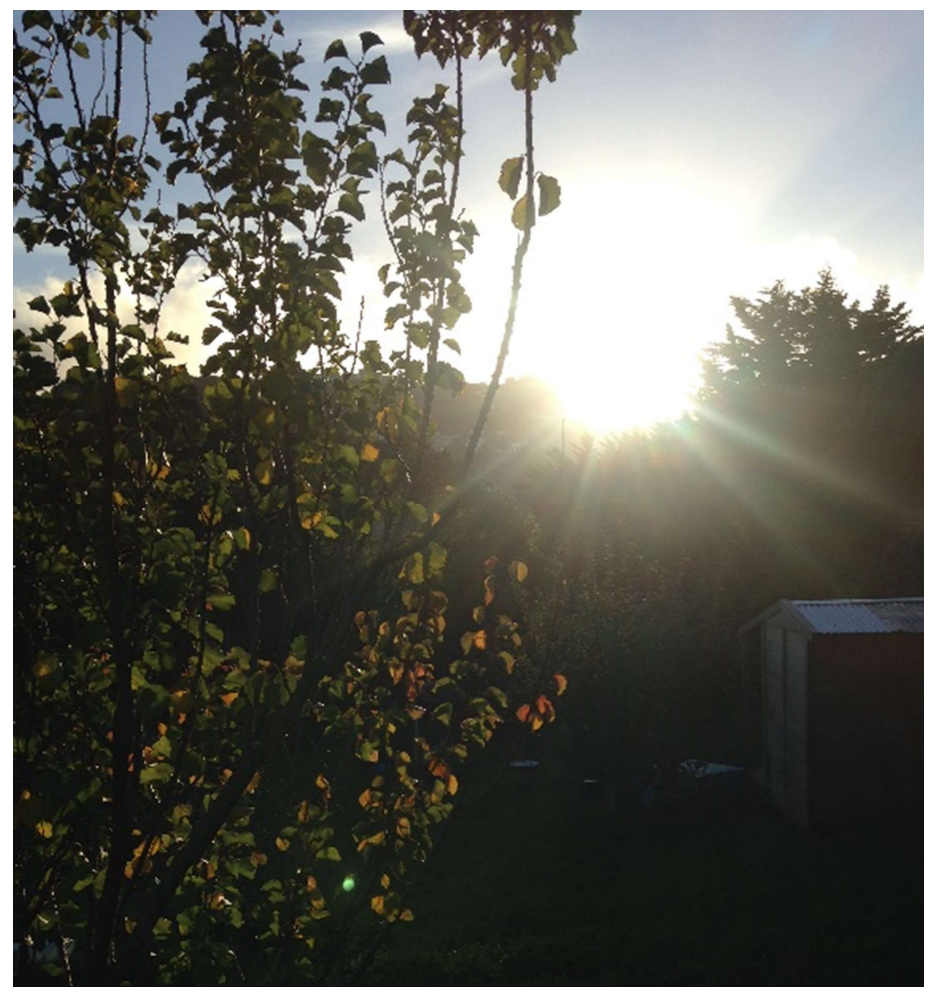

Figure 3 The sun sets through the Community Orchard

The sun was already low in the sky, filling the hillside with a soft light, and I was alone in a garden. The Community Orchard of Berhampore and Island Bay sits on the cusp of Island Bay, or the edge of Berhampore, near the southern coast of Wellington, Aotearoa. ${ }^{89}$ While the garden is signposted on Adelaide Road it seems to blend into the hillside, and it is not until wandering up a grassy path that the landscape of trees and garden beds emerge. I arrived early for my gardening session with Jan and I had been wandering the garden beds, taking notes on what grows where.

Lavender (Lavandula angustifolia) bushes bunch around the base of fruit trees, comfrey (Symphytum officinale) fills the in-between spaces, and nasturtium (Tropaeolum majus) weaves through it all. As I wandered, I crushed a lavender stem in my fingers, the smell reminding me of bedtime concoctions meant to send me to sleep and winter clothes brought out of storage. Later, Chloe tells me that the smell she associates with this garden is lavender, planted to attract bees to pollinate the orchard. This

${ }^{89} \mathrm{I}$ have used Aotearoa as the default name throughout this thesis, New Zealand is used in places where someone else has used it or contextually I deemed it more appropriate. 
relationship between a plant and its pollinator is a simple example of the shared heritage between species that exist in all ecosystems. In this garden, as in others, it is purposefully cultivated. ${ }^{90}$

This orchard was planted in July 2011, and the community garden was later transplanted here. As I meandered, I roughly sketched out the garden and tried to identify each tree. Most of them have hand-painted wooden labels, some with names I recognised like Granny Smith, and some which were obvious, like Apricot River. Others eluded me, like Triomphe de Vienna and Santa Rosa. I reached the highest point of the garden: here the gorse (Ulex europaeus) creeps down the hill, slowly absorbing the apple trees on the uppermost slopes. My wandering disturbed a blackbird (Turdus merula), which swooped in front and headed south.

Following the bird's flight, my gaze turned to where Te Ika a Maui meets Raukawa-Cook Strait, after which the ocean seems to stretch out forever. I imagined seeing from the bird's view as it soared higher than this hillside. Can the blackbird see across the strait and the hazy shape of the mountains that run the length of Te Wai Pounamu? I pictured the blackbird turning north and winging its way between the other community gardens I'd be visiting, flying along the ridgeline to Innermost Gardens in Mt Victoria, then ambitiously swooping to Khandallah Community Garden across the harbour, and finally onwards to Tawa Community Garden in the long valley heading to Porirua.

These gardens are rooted in the middle of Aotearoa, scattered through four suburbs within the city of Wellington. Lutz Warren, in her description of the colonisation of Aotearoa, writes of "towns of well-warmed houses with weeded gardens." ${ }^{\prime 91}$ From a distance, Wellington appears as just that. But these houses are not all warm, and not all these gardens are well-weeded.

I think of Wellington as a city made of hills, harbours and wind: valleys that northerlies sweep down and beaches where waves crash; southerlies from Antarctica to make your eyes water and bones shiver. There are draughts that creep through uninsulated walls, gusts that disturb your sleep and twist your washing into knots, tempests that uproot trees and tear through trampolines. It is a city located where it is

90 van Dooren, Kirksey, and Münster, 'Multispecies Studies Cultivating Arts of Attentiveness', 2.

${ }^{91}$ Julianne Lutz Warren, 'Huia Echoes', in Future Remains: A Cabinet of Curiosities for the Anthropocene, ed. Gregg Mitman, Marco Armiero, and Robert Emmett (Chicago, UNITED STATES: University of Chicago Press, 2018), http://ebookcentral.proquest.com/lib/vuw/detail.action?docID=4914481. 75. 
despite the wind. We have to hold on tight, or who knows where we might end up? But wind is not the only thing that blasts landscapes. The term blasted landscapes is applied to the places where anthropogenic impact is both obvious and obscured. ${ }^{92}$ The era of these blasted landscapes has been given many names, one of these is the Anthropocene. The Anthropocene was first put forward as a geological term by Eugene Stoermer and Paul Crutzen in 2000. It labels a new and recognisable geological epoch that has been "triggered by human actions." "The dating of this epoch is inexact: it could be the agricultural revolution 12,000 years ago, the Industrial Revolution of the $19^{\text {th }}$ century, or the nuclear tests of $20^{\text {th }}$ century. ${ }^{94}$

There is debate about both the geological definition and its failure to capture the political, social, and cultural aspects of human impact on Earth. The label continues to obscure the fact we are just one of many life-forms that share this living rock. Other names have been suggested; "Capitalocene, Plantationocene, Chthulucene, Whitesupremacy-cene." ${ }^{95}$ All these terms capture or challenge an aspect of the proposed Anthropocene, giving weight to one factor or another. What they all have in common is that they blast landscapes in some way and that these blasts leave ghosts and create monsters. ${ }^{96}$ In Gan et al the authors build on the idea of these ghosts and monsters. Ghosts become guides for exploring haunted landscapes while monsters describe both the forces that are driving the Anthropocene and the ecosystem entanglements that may thrive or survive it. The authors ask, "how can we pay better attention to overlaid arrangements of human and nonhuman living spaces, which we call 'landscapes'?"97 They go so far as to say our landscapes are haunted. ${ }^{8}$ I tend to agree.

The Anthropocene is just the last in a series of periods that geologists use to divide the history of Earth. Geological timescales were originally defined based on the

\footnotetext{
92 S Eben Kirksey, Nicholas Shapiro, and Maria Brodine, 'Hope in Blasted Landscapes', Social Science Information 52, no. 2 (2013): 230, https://doi.org/10.1177/0539018413479468.

${ }^{93}$ Rob Nixon, 'The Anthropocene: The Promise and Pitfalls of an Epochal Idea', in Future Remains: $A$ Cabinet of Curiosities for the Anthropocene, ed. Gregg Mitman, Marco Armiero, and Robert Emmett (Chicago, UNITED STATES: University of Chicago Press, 2018), 2.

${ }^{94}$ Stoermer and Crutzen favoured the beginnings of the Industrial Revolution. See Nixon, 2. 1945 fits more tidily with Tsing's blasted landscapes and the impact of nuclear tests.

${ }^{95}$ van Dooren, Kirksey, and Münster, 'Multispecies Studies Cultivating Arts of Attentiveness'. 3

${ }^{96}$ Gan et al., 'Introduction'.

${ }^{97}$ Gan et al., G1.

98 Gan et al., G2.
} 
soils and rocks of Europe. ${ }^{99}$ Translating the geology of Aotearoa to align with these international scales can be difficult. As GNS Science state in their introduction to the Geology of New Zealand, "The isolated position of New Zealand has made correlation with some other parts of the world difficult." ${ }^{100}$ Determining what defines the Anthropocene is just as difficult as any of these previous geological epochs. Each era has been spatially patchy, and global definitions obscure local differences.

The Anthropocene follows the Holocene, a relatively stable inter-glacial period that began around 12,000 years ago. While Homo genus began roaming in the Pleistocene, it was the Holocene that allowed Homo sapiens to begin in earnest to experiment with plants and animal companions. ${ }^{101} \mathrm{~A}$ stable climate enabled us to form multispecies relationships over millennia. The plants and fruit that had been gathered wild from human surroundings began to be deliberately cultivated in places near human settlements. ${ }^{102}$

The garden beds of Berhampore Island Bay Community Orchard reflect these Holocene entanglements. The orchard trees are largely domesticated varieties of fruit trees found wild in the Eurasian continent, the garlic (Allium sativum) plants have been found in 6000-year-old sites, the cultivation of asparagus (Asparagus officinalis) dates from at least $200 \mathrm{BC} .{ }^{103}$ With care and consideration, generations of humans have cultivated generations of these species for our own consumption.

While I call these Holocene entanglements, some say that agriculture marks the beginning of the Anthropocene. That as soon as we began to turn our hand to cultivation, not just gathering, we changed the Earth. ${ }^{104}$ In this definition, the Anthropocene swamps the Holocene and becomes more than the geological record changed by the radioactive fallout from nuclear bombs and the way we are influencing the weather through carbon dioxide emissions. It suggests that the way we have altered

${ }^{99}$ GNS Science, 'The Geology of New Zealand', GNS Science, accessed 16 February 2020, https://www.gns.cri.nz/Home/Our-Science/Land-and-Marine-Geoscience/Regional-Geology/TheGeology-of-New-Zealand.

${ }^{100}$ GNS Science.

${ }^{101}$ Di Paola, 'Gardens and the Anthropocene', 15-17.

102 Gan et al., 'Introduction'.

${ }^{103}$ Daniel Zohary, Ehud Weiss, and Maria Hopf*, Vegetables and Tubers (Oxford University Press, 2012), http://www.oxfordscholarship.com/view/10.1093/acprof:osobl/9780199549061.001.0001/acprof9780199549061-chapter-7.

104 Natasha Myers, 'From the Anthropocene to the Planthroposcene: Designing Gardens for Plant/People Involution', History and Anthropology 28, no. 3 (27 May 2017): 298, https://doi.org/10.1080/02757206.2017.1289934. 
other species, through centuries of cultivation, and how we have tilled the soil and harvested crops has significantly changed wider ecological systems. ${ }^{105}$

The patch of land that is now the community orchard has a deep story made of rocks and soil that a gardener's spade cannot reach, but some of the more recent human history is recorded. It was originally part of the town belt, established in $1841,{ }^{106}$ then in 1915 co-opted to form a golf course. ${ }^{107}$ The garden is located where the groundkeeper's cottage once stood - gardeners still find pegs from a long-gone washing line.

Gardening means changing the landscape. Before the orchard was planted in 2011, photos show a hillside of well-manicured lawns with some stately trees. ${ }^{108}$ Nine years later the difference is marked: the grass is freely growing, leaving droplets of water on my legs, and established orchard trees overlook the terraced garden beds. Yet not all changes can be seen above the ground. In the case of this patch, the soil of several garden beds was built from the earth of another community garden.

Common Ground community garden was based at Our Lady's Home of Compassion, a convent in Island Bay. Chloe, the current chair of the community orchard, began gardening at Common Ground in 2012 and was involved when in 2014 the church asked the gardeners to move on. In Chloe's words, "They'd spent nine years making the soil so good, and were then asked, 'can you pick up all your fruit trees and plants?"

Accepting this challenge, Chloe arranged to move the garden to the already established orchard. They gardeners spent a day bagging the soil and transferring it on the back of an ute. "We took the stuff we thought we could, until it got too much." Chloe witnessed the gardeners' anguish at being told to move on; “They were in so much grief, they didn't feel like they had the energy to start again in a new garden." Some of the gardeners moved on to other community gardens; others said they would

105 There is also a conversation about our cultivation of animal species in farms. Many in the academy are exploring this more specifically, for more on this topic see: Tsing, 'Earth Stalked by Man'. or Eben Kirksey, The Multispecies Salon (Durham: Duke University Press, 2014).

106 Timothy Beatley, 'Wellington, New Zealand: From Town Belt to Blue Belt', in Handbook of Biophilic City Planning and Design (Washington, DC: Island Press/Center for Resource Economics, 2016), 75, https://doi.org/10.5822/978-1-61091-621-9_7.

107 'MUNICIPAL GOLF LINKS.', New Zealand Herald, 1 November 1915.

108 'Community Orchard Berhampore and Island Bay Photos', accessed 10 February 2020, https:/ /www.facebook.com/photo.php?fbid=10154286950338336\&set=g.940700659376768\&type=1 \&theater\&ifg $=1$. 
start again at Berhampore but never turned up. Chloe wonders if they simply could not overcome the sadness of losing one garden. It is obvious that gardeners care for the landscapes that their gardens grow in, but the relationship built in relation to one patch may not be easily transplanted.

From my perch at the top of the hill, I saw a woman walk up from the road carrying a spade. It was time to stop wandering between the plants, and wondering about ghosts and monsters, and time to begin gardening. The blackbird reappeared and looked at me quizzically - we are never alone in a garden.

Patch two: Khandallah Community Garden

It was a sunny day and I was pulling out nasturtium (Tropaeolum majus) at the Khandallah Community Garden. There were five gardeners there that day, each working away on a different patch of the garden in a comfortable silence. The stems of the nasturtiums had tangled through each other to form loose green braids; by tugging on one I could easily pull three to four plants out of the soil. The plants piled up behind me. In an effort to make the material fit into a much too small bag, I had to stomp on them. They made the air smell sharp, peppery, and a deep breath filled my lungs with a tingling sensation.

The Khandallah garden is small - driving past you might well blink and miss it. But there is a lot packed into this small space, including fruit trees, strawberries (Fragaria $\times$ ananassa), and beautiful broad beans (Vicia faba) with magenta flowers. Feijoa trees (Acca sellowiana) line the edges and a small book exchange sits beside an outdoor table. There is a sub-station sending electricity out to the local area. In the centre there is a pohutukawa (Metrosideros excelsa) with an impressive insect hotel attached to it - the gardeners ironically refer to it as a resort. As I paused from my weeding, a blackbird settled on one of its branches.

Khandallah settles itself over the northern hills of Wellington. Roads wind through the suburb, and wind rushes over the hilltops and into the harbour below. I have learnt that blackbirds can easily fly the distance between my community garden 
sites, but they are strongly territorial so normally stick to one preferred patch. ${ }^{109}$ To get to Aotearoa they travelled much greater distances than across a harbour, and not by flight.

On 8 April 1862, the Cashmere sailed into Auckland Harbour carrying wild English songbirds. ${ }^{110}$ Inspired by the successful acclimatisation of English birds into Australia, the hope was to bring the sounds of home to the new colony. ${ }^{111}$ Twelve blackbirds had started the journey - ten completed it. The blackbirds did not come willingly: they were "wild caught" then transported in cages across the globe. This migration was part of the wider project of acclimatisation undertaken as an attempt to re-make the colonies in the image of their imperial centres. ${ }^{112}$ It was not apolitical - the newspaper report on the blackbirds' arrival concludes, "may they thrive in their bloodless and unobtrusive mission of colonisation." 113 This was a method of settling ourselves by bringing companion species to make us feel at home. ${ }^{114}$

Several decades earlier, in 1839/1840, the New Zealand Company had begun the colonisation of the area. The creation of the town called Wellington began with a failed and fraudulent settlement in Pito-One, later renamed Britannia and then Petone. ${ }^{115}$ The land was too swampy, and the weather was rotten. The low-lying location provided no shelter to the southerly gales, and Te Awakairangi flooded the settlement while the surveyor pegs were still being laid. ${ }^{116}$

The New Zealand Company mapped out Wellington in a grid. ${ }^{117}$ There would be squares for gatherings, there would be gardens, and a town green belt would wrap

\footnotetext{
109 'Eurasian Blackbird | New Zealand Birds Online', accessed 10 February 2020, http://nzbirdsonline.org.nz/species/eurasian-blackbird.

110 'Miscellaneous.', Wellington Independent, 2 October 1862.

111 Australia was thought to be "naturally destitute of the song-birds whose carols are so grateful to the ears of the colonists, and so fruitful of suggestions of home." 'Miscellaneous.'

112 'Misc acclimatisation societies in New Zealand see Paul Star, 'Human Agency and Exotic Birds in New Zealand', Environment and History 20, no. 2 (2014): 275-99.

113 'Miscellaneous.'

114 Star, 'Human Agency and Exotic Birds in New Zealand', 281.

115 Matiu Rei, 'Edward Gibbon Wakefield: A Ngati Toa View', in Edward Gibbon W akefield and the Colonial Dream: A Reconsideration., by Friends of the Turnbull Library (Wellington, N.Z: Friends of the Turnbull Library, 1997), 195-97.

116 Grahame Anderson, 'Wakefield Towns', in Edward Gibbon Wakefield and the Colonial Dream: A Reconsideration., by Friends of the Turnbull Library (Wellington, N.Z: Friends of the Turnbull Library, 1997), 147.

117 Anderson, 147.
} 
itself over the hills. The colonial town centre of Wellington was edged by farms. Khandallah was a homestead on the northern hills, Tawa a small village surrounded by farms on the way to Porirua, and Berhampore an estate before you reached the fishing village of Island Bay.

Settling is a remarkably gentle word used to describe a process that involves the building of new homes over the top of someone else's land. In truth the process was, and continues to be, as much about unsettling as it is about settling. ${ }^{118}$ One tool used to unsettle was through re-naming the landscape. Naming is a way humanity connects and attempts to control places. ${ }^{119}$ The Pākehā migrants settled by re-naming and claiming, cultivating and harvesting this landscape. But past names are not erased: This harbour is called Te Whanganui-a-Tara, or the great harbour of Tara, one of the first explorers of Aotearoa. ${ }^{120}$ Rachel Buchanan describes the landscape her t ūpuna knew:

They settled at Te Aro, the pā that still lies beneath Taranaki Street, and they grew their veges up the hill at Pukeahu, the place that became known as Mount Cook, and they caught their fish in the harbour, beetling about on waka with their relatives. ${ }^{121}$

Many of the names stamped across Wellington have origins in our colonial past; the names form "time-knots" linking places in one colony back to another and the wider impacts of colonisation. ${ }^{122}$ The name Khandallah itself has an ambiguous lineage - it is possibly named after the Khandala Hill Station in Western India, anglicised as Khandallah. ${ }^{123}$ Yet for years, it was locally thought to mean either the "Resting place of God" or "hills and valleys". ${ }^{124}$ Nobody quite knows what language that these translations can be attributed to. It is a ghost word, divorced from its origins. Here the

${ }^{118}$ Here I am using unsettle to term the way colonisation displaced other societies. For an exploration about how the response to settling needs to be unsettling too. See Eve Tuck and Wayne Yang, 'Decolonization Is Not a Metaphor', 8 September 2012, https://www.researchgate.net/publication/277992187_Decolonization_Is_Not_a_Metaphor.

${ }^{119}$ Smith, Decolonizing Methodologies, 158-59.Tuhiwai Smith

${ }^{120}$ Hinemoana Baker, 'Ka Aro Au (Cuba Street Song) - Pukeahu Anthology', accessed 7 February 2020, http://pukeahuanthology.org/stories/migrations/ka-aro-au-2/.

${ }^{121}$ Rachel Buchanan, Ko Taranaki Te Maunga (Wellington: Bridget Williams Books, 2018), 26.

122 Deborah Bird Rose, Reports from a Wild Country: Ethics for Decolonisation (Sydney: University of New South Wales Press, 2004), 25.

123 'Notes on the Road Home', Otago Witness, 27 July 1872.

${ }^{124}$ Amber-Leigh Woolf, 'Khandallah’s Homage to India', Dominion Post, 2 October 2017. 
old empire lies heavy, a tangle of asphalt weaving distant geographies and colonial power onto ancient greywacke. The garden sits at the corner where Mandalay Tce, ${ }^{125}$ Onslow Rd, ${ }^{126}$ and Cashmere Ave ${ }^{127}$ meet. An intersection of names from the former British Empire revealing the tangle of connections that existed between this landscape and those. ${ }^{128}$

The four community gardens I visited are built on patches of public land strewn across the landscape. They all have ties to the colonial past. For some in their names like in Khandallah and Berhampore harks back to Baharampur, a fort town in West Bengal occupied by the East India Company. ${ }^{129}$ Tawa Community Garden is positioned on Coronation Park, opened as a reserve soon after Queen Elizabeth II was crowned Queen of the United Kingdom, Canada, Australia, New Zealand, South Africa, Pakistan, and Ceylon. ${ }^{130}$ While Innermost Gardens sits on the side of Mt Victoria, where Queen Victoria's name drapes over those used previously, Tangi te Keo for the peak and Matairangi for the hillside. ${ }^{131}$

I caught the train to the Khandallah garden, through the tunnels and gullies that lead out of the centre of this windy city. The edges of the tracks were coated in weeds. I could make out banks of tradescantia (Tradescantia fluminensis) on the hillside as the train slowed before a tunnel. The gorse was in bloom and, in one place, it seemed like it may even brush the side of the train. It was sunny, so to look out the window required me to squint. My eye is instinctively drawn first to larger landscapes, the valleys, hills and harbours. There is a layer of modernity I tend to squint away from -

\footnotetext{
125 Burma's royal capital before annexation by Britain.

126 The Governor General of New Zealand 1889 - 1890.

${ }^{127}$ Named after Kashmir where tensions continue to flare.

128 James Beattie, 'Plants, Animals and Environmental Transformation: Indian-New Zealand Biological and Landscape Connections, 1830s-1890s', in The East India Company and the Natural World, ed. Vinita Damodaran, Anna Winterbottom, and Alan Lester (London: Palgrave Macmillan UK, 2015), 219-48, https://doi.org/10.1057/9781137427274_11.

${ }^{129}$ Merriam-Webster, 'Baharampur', in Merriam-Webster's Geographical Dictionary, 2007, https://searchcredoreference-

com.helicon.vuw.ac.nz/content/title/mwgeog?institutionId=5378\&tab=entry_view\&heading=baharam pur\&sequence $=0$.

${ }^{130}$ Coronation Park (Lots 26, 27, 28, and 29) was registered as a reserve in 1954. 'THE NEW ZEALAND GAZETTE', 19 August 1954, http://www.nzlii.org/nz/other/nz_gazette/1954/50.pdf.

131 Wiremu Grace, 'Ngake and Whātaitai the Taniwha of Wellington Harbour', Home - Mātauranga Māori, accessed 6 February 2020, http:/ / eng.mataurangamaori.tki.org.nz/Support-materials/Te-ReoMaori/Maori-Myths-Legends-and-Contemporary-Stories/Ngake-and-Whataitai-the-taniwha-ofWellington-harbour.
} 
the trappings of modern infrastructure that keep a city's heart ticking. ${ }^{132}$ The geological processes and colonial processes form layers still present in the landscape. But the layering continued from there.

The Khandallah Community Garden demonstrates exactly how the layers of modernity sit within our landscapes. Until five years ago, this patch of land was unused road reserve next to the small substation and full of long grass and weeds. The gardeners described it to me as unloved. They approached the council for permission to start a community garden and were granted a ten-year lease. What they did not know was that under the grass, the roots, and the soil lay extensive wires and piping. The section is an intersection not just of roads, but of the hidden infrastructurerequired to keep modern life running. As a result, for most of the Khandallah garden there is a no-dig rule: don't dig anywhere unless you know what lies underneath, stick to the established raised beds, and be careful.

\section{Patch three: Tawa Community Garden - Octopi and squirms}

The suburb of Tawa takes its name from the tawa tree (Beilschmiedia tawa). Before human arrival in Aotearoa the majority of Upoko o Te Ika would have been forest, now only $27 \%$ remains, mostly replaced by pasture. ${ }^{133}$ Tawa dominated the canopy in areas of high rainfall, limited by the rain-shadow that is caused by the Tararua and Remutaka ranges. The name tawa links, through genealogies of language and exploration, to the Asian continent. It is the name given to the Pometia pinnata, a large hardwood that grows throughout the Pacific Islands and South-east Asia. Its berries are used as a food source. ${ }^{134}$

The tawa indigenous to Aotearoa was also once a common component of the diet of tangata whenua. Makereti Papakura (Te Arawa) ${ }^{135}$ described the process

\footnotetext{
132 Gibson, Katherine, Rose, Deborah Bird, and Fincher, Ruth, eds., Manifesto for Living in the Anthropocene (punctum books, 2015), vi, https://doi.org/10.21983/P3.0100.1.00.

133 Nick Singers, Philippa Crisp, and Owen Spearpoint, 'Forest Ecosystems of the Wellington Region' (Greater Wellington Regional Council, December 2018), 5.

134 'Te Māra Reo’, accessed 16 February 2020, http:/ /www.temarareo.org/PPN-Tawa.html.

135 Makereti Papakura (1873 - 193) was also known as Maggie Papakura and Margaret Pattison Thom. Papakura wrote The old-time Maori as a thesis at Oxford University. "The book has a unique place as the first extensive published ethnographic work by a Maori scholar" - June Northcroft-Grant. 'Papakura, Makereti', Dictionary of New Zealand Biography, first published in 1996. Te Ara - the Encyclopedia of
} 
involved in preparing tawa berries for eating. She states they could be eaten fresh "as a fruit" and that they were "juicy and not unpleasant to taste." 136 But it was the kernel that was prized as a food that could be stored for long periods. The processes of preparation involved steaming then drying them in the sun before being stored. After being dried they would be soaked and steamed before eating. Papakura claimed that they were not an unpleasant food, "We had plenty when I was a child and I used to enjoy them. With a little sugar, they were very nice indeed". ${ }^{137}$

The tawa was recorded by Joseph Banks on the Endeavour's first trip to Aotearoa in 1769 -70. Tuhiwai Smith describes how Joseph Banks observed both the humans and botany of Aotearoa in his journals. ${ }^{138}$ Here Banks is already evaluating the land with an eye for extractive resources and the potential of the soil to "make ample returns of any European vegetables grown on it."139

The tawa faces an additional challenge in survival, humans have not only fragmented its distribution, but also fragmented the species entanglements that enable its dispersal. There are now only two surviving bird species in Aotearoa able to swallow the tawa seed whole, allowing for successful dispersal, the kererū (Hemiphaga novaeseelandiae) and the kokakō (Hemiphaga novaeseelandiae). ${ }^{140}$ The kererū is still found in the Wellington region, but kokakō populations have been decimated by introduced predators. ${ }^{141}$ This is the very example used by Gan et al to describe "landscapes haunted by past ways of life." 142 They are broken entanglements that leave eerie gaps in ecosystems.

In the octopus garden plants grow, humans run,

New Zealand, https://teara.govt.nz/en/biographies/3p5/papakura-makereti (accessed 6 December 2019).

${ }^{136}$ Makereti Papakura, The Old-Time Maori, New Zealand Electronic Text Collection, 2005 (Wellington, NZ: Victor Gollancz Ltd London, 1938), 207, http://nzetc.victoria.ac.nz/tm/scholarly/teiMakOldT.html.

137 Papakura, 207.

138 Smith, Decolonizing Methodologies, 83.

139 Smith, 84.

${ }^{140}$ Dave Kelly et al., 'Mutualisms with the Wreckage of an Avifauna: The Status of Bird Pollination and Fruit-Dispersal in New Zealand', New Zealand Journal of Ecology; Christchurch 34, no. 1 (2010): 66-85.

141 Kelly et al.

${ }^{142}$ Gan et al., 'Introduction', G2. 
and insects hum.

Tawa Community Garden sits on the front half of Coronation Park in Tawa. The roadside berm is planted with lush flower bushes. I did not recognise a lot of them, but my garden host Alison listed borage, marigolds and daisies. It was a storybook image of a well-tended garden, and even with a grey sky it seemed to brighten the day. I commented how lovely it looks, and Alison told me this area is about encouraging bees to the area to help pollinate crops.

Behind the flower garden and the white picket fence lie the garden beds. There are four raised beds, built by a band of trusty Scouts, and an original garden designed in the shape of an octopus. The hope was that the eight paths would appeal to children. Alison, my garden host, tells me that it does. Recently, visiting Brownies ran around the octopuses' legs "like a swarm of bees." It attracts bees of the insect type too. She showed me a delightfully wild patch of self-seeded flowers. Instead of thinking of these plants as weeds, Alison thinks of how each plant might benefit the wider ecology, for example providing food for the bees that are necessary for pollination. While Alison prefers everything to be set out nicely regimented, like the newer raised beds, she can still appreciate the appeal of the Octopus. She noted, "It is meant to have eight tentacles, but I think we have lost at least one, which does happen to octopuses."

My mind took me on a tangent. It is an octopus garden on an ancient riverbed, not an Octopus's garden under the sea. But that does not stop me getting the song in my head. "I'd like to be under the sea, in an octopus's garden in the shade... we would sing and dance around because we know we can't be found..." ${ }^{143}$ I'm not looking for an anthem for the Anthropocene, but a song written about the way octopuses build so-called gardens out of stones by a band whose name alludes both to multispecies companions and motorcars seems to hit all the right points. The song was written fifty years ago, yet the Beatles inadvertently captured one response to the Anthropocene, the desire to run away instead of standing and facing our troubles.

Haraway, the exponent of staying with the trouble and stirring it up too, has a fondness for things with tentacles. She accepts the Anthropocene as an event but proposes that it is a demarcation between two epochs rather than an era. Her call is for

143 The Beatles, Octopus's Garden (EMI Studio London: Apple, 1969). 
humankind to think about what will come next and who will be our kin in the next epoch. A wordsmith, she suggests the Chthulucene, named after "the diverse earthwide tentacular powers and forces and collected things," 144 must be worked with, rather than against. Her call is that we stay with the trouble ${ }^{145}$ that we do not try and run to an octopus's garden or bury our heads in the ground. This charming garden in Tawa feels faraway from blasted landscapes and the troubles of the Anthropocene. This is a patch of liveability. ${ }^{140}$

With our tour completed, Alison headed to the garden shed to get some tools and I turned to find my now familiar garden companion, the blackbird. A new load of compost had been spread onto one of the raised beds, and the blackbirds were arriving to rummage through the dark soil. First, they raked the soil with their feet, claws taking the place of iron teeth, then the bright yellow beaks snapped at their prey. I had been seeing a lot of blackbirds at my community gardens and they have got me questioning how we perceive landscapes. The term bird's-eye view describes the big picture, the sweeping arc - the landscape-scale size of things. But is that really what a bird squints in to focus on? These blackbirds seem more concerned with the close-up view from the ground than the sky.

As I stand here, I observe a bird swallowing a worm. The process takes several gulps, each gulp sending the twitching pink worm further down the bird's throat. I blink twice and the worm is gone. Haraway asks us to turn from the sky to the mud, much like the blackbirds, and consider our relationships to the species that dwell there ${ }^{147}$ Humans, though we live on the ground, are not a species of the soil. We can only ever glimpse the life that lives under us. Hidden in the soil there are unknown numbers of worms in New Zealand. Some species have been here for millennia; there are over 150 species of indigenous worms in Aotearoa. They have been squirming in the earth since the Cretaceous period 65-145 million years ago. ${ }^{148}$ They do not like to be disturbed and exist in those patches of earth far from the spade and the trowel. The challenge we face is trying to listen to languages we cannot imagine. Do they

\footnotetext{
144 Haraway, 'Anthropocene, Capitalocene, Plantationocene, Chthulucene', 160.

${ }^{145}$ Haraway, Staying with the Trouble, 1.

146 Tsing, 'Getting by in Terrifying Times', 73.

${ }^{147}$ Donna Haraway, When Species Meet (Minneapolis, United States: University of Minnesota Press, 2007), 4.

148 Gregor Yeates, 'Earthworms - Earthworms in New Zealand', Te Ara - Encyclopedia of New Zealand, 24 November 2008, https://teara.govt.nz/en/earthworms/page-3.
} 
remember the tremor of the earthquake raising the land in 1855? When the swamps of Te Aro were drained and the forests cut down, did they retreat ${ }^{149}$ Have they noticed that the Holocene is ending?

As the European settlers arrived in Wellington, so did their gardens and, along with the gardens, companion species. The worms of our gardens travelled with the earth of early settlers. Seventeen introduced earthworm species now make their homes in gardens and pastures across the country. They came as stowaways stuck below deck in the soil used to ballast the ship, or in the pots of plants brought to remind humans of the homes they'd left. ${ }^{150}$ Could the worms tell there was ocean beneath them? How does the breaking of waves compare to the pattering of rain on a garden's soil? Did the world vibrate at a different frequency when they arrived? That worms live their lives out of the sun should not be mistaken as living separate to the weather - too wet or too dry is bad, as is too hot or too cold. ${ }^{151}$

In 2019, these worms are spoken of with reverence by the gardeners I speak to. Their presence is taken as a sign that the soil is healthy and that plants will do well in that spot. What worms do best is assist in the decomposition of the organic matter in the soil. The decomposing of matter is their reason for being. Entanglements with each other and the earth come naturally to them. I, and the gardeners I meet, care about where the worms are and how they are doing. Worms remind us that gardening is a type of caring. Tending a garden involves identifying the companions that we care for and the companions caring for us in return.

For all the reverence, there is a practicality present too. I end up with a small pink worm from the compost on the palm of my hand; it is only the length of my little finger. It is pulsing its muscles; segments enlarge and shrink, and it feels dry to the touch. It is not unpleasant exactly, but it is unfamiliar, a sensation that makes me squirm. A collective term for worms is squirm and the consensus is that gardens need squirms. I shake this single member of the squirm into the garden bed and Alison tells me that there are differences between those that live in the compost, the worm farm

\footnotetext{
149 Buchanan, Ko Taranaki Te Maunga, 31.

${ }^{150}$ Yeates, 'Earthworms - Earthworms in New Zealand'.

151 Paul Eggleton et al., 'A Six Year Study of Earthworm (Lumbricidae) Populations in Pasture Woodland in Southern England Shows Their Responses to Soil Temperature and Soil Moisture', Soil Biology and Biochemistry 41, no. 9 (September 2009): 1857-65, https://doi.org/10.1016/j.soilbio.2009.06.007.
} 
and the garden beds. This worm I've discarded is unlikely to survive but in Alison's words, "never mind we can't protect every worm."

The idea of the Anthropocene makes me squirm; the easiest option would be to run away. But some level of discomfort is required when dealing with the scale of degradation caused by man. Perhaps feeling the squirm is another way of staying with the trouble.

\section{Patch four: Innermost Gardens (Mt Victoria)}

Building a new garden bed at Innermost Gardens in Mt Victoria involved disturbing a squirm of worms. They formed one clump, twisting themselves around each other before; moments later, the worms were gone, having tunnelled their way back to the safer depths. This thriving tangle of life is a far cry from this description, "Urban soils are typically compacted, chemically damaged, and relatively devoid of life." ${ }^{\prime 152}$ These words appear on the website of Innermost Gardens describing the state of the soil when they are arrived.

Innermost Gardens inherited the space from the Mt Victoria bowling club which had been operating there since the 1950s. In photos from 2010, the area waiting to become the Innermost Gardens is all lawn with concrete edges. The intervening years have been about filling the space with soil. The section to the north of the house contains communal plots. To the south lies a wetland area planted in natives and the beginnings of a food forest of assorted orchard trees. Beyond that a section is divided into allotments, allowing individuals to indulge their own garden dreams. Here you can observe the diverse ways different people approach their gardening.

Like at Berhampore, two contrasting ideas can be seen at play - the straight lines and order of the old club-grounds merging with weaving pathways and plants over the top. The history of the land is being slowly hidden from sight. Chris tells me, "It would have been a monoculture before the gardens moved in here. The beauty of it, going from monoculture to deepest permaculture."

152 'Innermost Gardens', accessed 11 February 2020, https:// sites.google.com/view/innermostgardens.Innermost Garden website. 
You cannot build a garden without companions, but we've tried. Chris talks to me about her parents' penchant for sprays, "I brought my mum up to the gardens and she said, 'it is a bit messy,' and I'm like 'there is so much diversity! We don't spray Mum... there is no Round-Up here.' She is all clipped hedges and straight lines. 'Why would you just let calendula self-seed everywhere?' and I say, 'why not?' Instead of having an empty bed?" Chris looks at her community garden as being "as inclusive as possible, for the plants, the people and the bugs."

A garden is not always inclusive. The pesticide revolution of the 1900 s and the associated tools made possible large-scale blasting of landscapes. ${ }^{153}$ A 1950s Australian garden guide spoke of how pesticides could be used to achieve the desired outcome of "a garden devoid of insect life." ${ }^{154}$ Companies prioritised profits over people and our garden companions. Advertisements from the NZ Gardener magazine show similar attitudes advising to spray your compost heap for your family's health. ${ }^{155}$ In Gaynor's words, "Ultimately industrial chemistry, as a servant of capitalism, was more concerned with profit than questions of long-term safety." 156 The power of pesticides was harnessed to support tidy lawns and leisure grounds such as the Mt Victoria bowling club.

A bowling green requires a flat even surface, good drainage, sunshine and a location easily accessible by the community; all things that can contribute to a community garden. A bowling green does not need to harbour much life. When the gardeners moved into the space in 2010, they found high traces of DDT. It had been used to maintain a uniform and monocultural lawn over previous decades. Fit for its previous purpose but not fit for gardening.

DDT stands for dichloro-diphenyl-trichloroethane and was recognised as an insecticide in 1939. ${ }^{157}$ It formed an important tool in the creation of neat gardens. It killed indiscriminately, not only targeting pests, such as the white butterflies, but also

\footnotetext{
${ }^{153}$ Michelle Mart and Cameron Muir, 'The Manual Pesticide Spray Pump', in Future Remains: A Cabinet of Curiosities for the Anthropocene, ed. Gregg Mitman, Marco Armiero, and Robert Emmett (Chicago, United States: University of Chicago Press, 2018).

${ }^{154}$ Gaynor, Harvest of the Suburbs, 129.

${ }^{155}$ Quoted in Jo McCarrol, 'The History of Gardening in New Zealand: Revealed by 75 Years of NZ Gardener', NZ Gardener, September 2019, https://www.stuff.co.nz/life-style/homed/115385521/thehistory-of-gardening-in-new-zealand-revealed-by-75-years-of-nz-gardener.

156 Gaynor, Harvest of the Suburbs, 152.

157 Gaynor, 125.
} 
any insects, such as wasps, that might prey on the "pests". ${ }^{158}$ Ecological entanglements being blasted by chemical compounds. The use of DDT reflected the philosophy of the time.

The gardeners who established Innermost were not deterred by the DDT in the soil. To get it back in shape they turned to the humble oyster mushroom (Pleurotus spp.). Oyster mushrooms were "seeded" onto the former bowling green, absorbing the toxins in the soil through a process known as mycoremediation. ${ }^{159}$ Twelve years later the soils are now safe and mushroom projects are again underway at Innermost Gardens, with mushrooms growing on bags in the gardening shed. I find them beautiful, their delicate filaments mesmerising.

Mushrooms make an interesting companion species. Tsing follows the matsutake (Tricholoma matsutake) around the world, from the remnants of the great redwood forests in Northern California to the pine forests of Japan. ${ }^{160}$ She asks us to consider what happens to landscapes after the blast. She connects these earthy mushrooms with the nuclear mushrooms - the blasts that drew definitive lines in geological time. In Aotearoa we are proudly nuclear free, yet even here we are haunted by the impact of man's harnessing of the atom. ${ }^{161}$ In the 1960 s the radioactive isotope Strontium-90 was present in the milk given to school children. ${ }^{162}$

How we can ensure liveable habitats remain? ${ }^{163}$ How do we interact with our squirming companions in the tangles of the Anthropocene? Gardening requires us to consider which species we are seeking to encourage and which we are willing to accept will turn up regardless; not to celebrate all life uncritically, but to actively consider liveability and its entanglement with un-liveability. Gardening can centre humankind above all else, but to garden [for | in] the Anthropocene means centring liveability for more-than-humankind.

158 Gaynor, 125.

159 Meena Kapahi and Sarita Sachdeva, 'Mycoremediation Potential of Pleurotus Species for Heavy Metals: A Review', Bioresources and Bioprocessing 4, no. 1 (2017): 1, https://doi.org/10.1186/s40643-0170162-8.

160 Tsing, The Mushroom at the End of the World.

${ }^{161}$ Rebecca Priestley, Mad on Radium: New Zealand in the Atomic Age (Auckland, UNITED STATES: Auckland University Press, 2013), http:/ / ebookcentral.proquest.com/lib/vuw/detail.action?docID=1412035.

162 Priestley, 129.

163 Tsing, The Mushroom at the End of the World. 


\section{Please weed: weeds and boundaries}

The plants that colonised new ecosystems in the footsteps of humans have been proposed as one lineage of the Anthropocene. ${ }^{164}$ Cultivating gardens means cultivating weeds, those plants that grow in the waysides of human-disturbed landscapes. If gardens are suggested as a place for cultivating liveability in the Anthropocene, the question must be asked liveability for whom? Here ideas of human knowledge and control are explored through entanglements with plants that have been classified as weeds. It shows that gardens are parts of wider landscapes that are interdependent.

The weed travelled

The weed travelled, across

an ocean,

powered by the

wind and the tides.

(We had not yet learnt how to fly...)

Returned to land,

it became

a footstep that grew,

rather than

faded.

${ }^{164}$ Ellen R. Butcher and Dave Kelly, 'Physical and Anthropogenic Factors Predict Distribution of the Invasive Weed Tradescantia Fluminensis', Austral Ecology 36, no. 6 (2011): 621-27, https://doi.org/10.1111/j.1442-9993.2010.02196.x. 


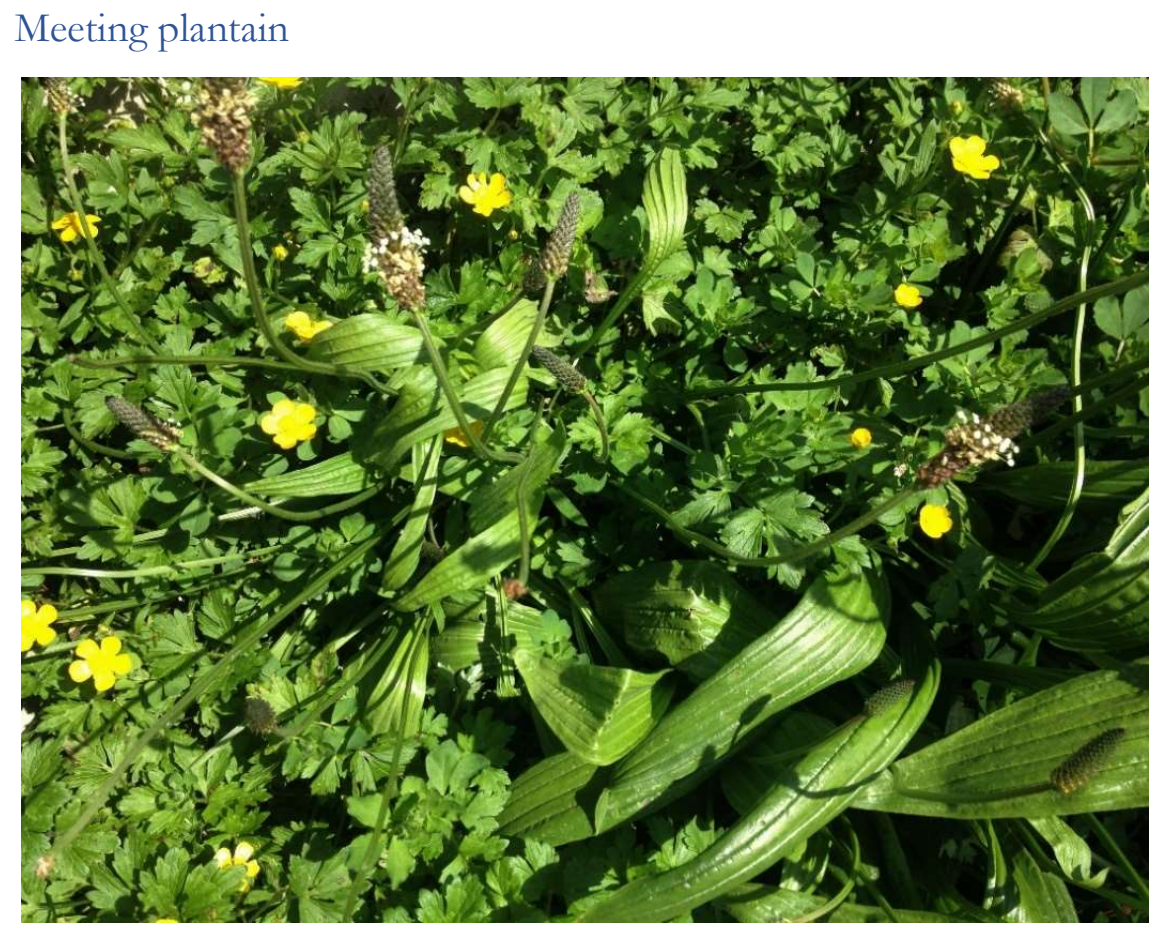

Figure 4: An entanglement of plantain and buttercup

My first day gardening was at the Community Orchard in Berhampore. It was a sunny autumn day - the sort of day that makes gardeners smile at each other and say, 'great day for gardening'. Chloe was there when I arrived, and the first task was weeding.

I had forgotten to bring my own gloves and the soil was cold and damp on my skin. The unwanted plants were reluctant to relinquish their hold on the soil, and strong tugging was required to pull out the plant, roots and all. The roots came coated with a sticky layer of soil. I made the mistake of shaking them and splatters of dirt caught in my eye. We were mostly taking out creeping buttercup. Its Latin name, Ranunculus repens, means creeping frog, too sweet a name for a plant which is almost impossible to remove. I'm quite familiar with the frustrations of buttercup from my home garden and, when I correctly identified it, Chloe gave me an approving nod and said, "You know things."

Chloe tries to space out the task of weeding so that it's not on the list at every working bee. She feels weeding cannot be all that is required from volunteers in a community garden, otherwise things get tedious, so she tackles it during her regular 
Monday garden time - like the day we met. As we weeded and chatted, Chloe pointed out the ribwort plantain (Plantago lanceolata) and asked me to leave them as they are edible. Curious, I picked a few plantain leaves and stuffed them in my back pocket. I forgot about them until, days later, I reached into my pocket to find the leaves completely dried out. They crinkled to dust between my fingers. Not much of a snack!

To learn more about the plants I hadweeded, I turned to An Illustrated Guide to Common Weeds of New Zealand. ${ }^{165}$ I flicked through the pages, discovering the identities of many plants I have met - and on some occasions killed - but have never been able to name. I found P. lanceolata and learn it thrives in "lawns, gardens, road-sides, waste places, pastures and open disturbed places". ${ }^{166}$ Its leaves are distinctive if you know what you are looking for, stretched out ovals with ribs running the length of them. Covered in fine white hairs, it feels smooth to touch. Once aware of it, I begin to see it everywhere; in the other community gardens, down the side of the steps to university, on a shortcut I take through the town belt. Plantain inhabits these unruly patches beyond the mower's blade, a green plant camouflaged amongst many other green plants.

The name plantain is used interchangeably for various plants in the Plantago genus. The ribwort plantain and the broadleaf plantain (Plantago major) are both commonly considered as human companions. Both are edible and have a long history of human use for all sorts of ailments, including wound healing. ${ }^{167}$ They grow in the cracks of human cultivation, dancing between desirable medicinal companion and ignored tag-along.

In North America, plantain was called white man's foot. Indigenous people found it trailing European colonisers across the continent. ${ }^{168}$ In Aotearoa, its spread outpaced the British settlers: in 1842, a surveyor of the Motueka District found plantain growing near extensive potato plots cultivated by local iwi. ${ }^{169}$ By 1855 , Plantago lanceolata had become naturalised in Aotearoa, meaning it was considered able to

\footnotetext{
165 Bruce Roy, An Illustrated Guide to Common Weeds of New Zealand, ed. New Zealand Plant Protection Society (Lincoln, N.Z: New Zealand Plant Protection Society, 1998), i.

166 Roy, 207.

167 Gabrielle Hatfield, Hatfield's Herbal: The Secret Society of British Plants (London: Penguin, 2007), 292-93.

${ }^{168}$ Larry W. Mitich, 'White Man's Foot: Broadleaf Plantain', Weed Technology 1, no. 3 (1987): 1-2.

169 Officer of the Surveying Staff, 'The Motuaka District.', Nelson Examiner and New Zealand Chronicle, 13 August 1842.
} 
successfully "reproduce in the wild". ${ }^{170}$ Over 160 years later, it appears to have wellestablished roots in the Wellington landscape.

Jennifer Atchison, a researcher into human entanglements with weeds, argues that "invasive plants" act in ways "that are not always easily predicted or imagined by the humans involved," as a result challenging the humans seeking to manage them. "The plants defy the boundaries that are drawn around them, or at least it is possible to see that the demarcations human envisage cannot be so firmly fixed." 171 There is the anthropocentric line "that a weed is only a plant we have not found a use for". Of course, a plant is still a plant regardless of whether humans have a use for them. More frequently it would seem weeds are plants that have successfully found a use for humans.

\section{Broken borders}

Halfway through my gardening with Chloe at Berhampore, Cathy arrived. She brought with her a sense of purpose and energy. Cathy likes sharing ideas with others while being active. She thinks of the garden as an experimental and safe green space; somewhere people can come and see ways of living sustainably. Cathy pointed out to me the gorse (Ulex europaeus) creeping down into the garden from the town belt above. The gorse forms an impenetrable hedge and completely surrounds the apple trees on the very upper slopes. One of Cathy's goals is to maintain the space around these trees. She calls it her "mini obsession".

That gorse forms the boundary between the cultivated and uncultivated space is appropriate, harking back to its heritage as a hedge plant used to mark boundaries across the British countryside. Gabrielle Hatfield, in Hatfield's Herbal: The Secret Society of British Plants, explores the relationship between certain plants and humans on the British Isles. In Britain, gorse was considered indispensable: its applications were multiple, including as firewood, fodder for cattle, and dyeing. ${ }^{172}$ British settlers brought

${ }^{170}$ New Zealand Plant Conservation Network, 'Plantago Lanceolata', New Zealand Plant Conservation Network, accessed 4 February 2020, http://www.nzpcn.org.nz/flora_details.aspx?ID=3019.

171 Jennifer Atchison, 'Thriving in the Anthropocene: Understanding Human-Weed Relations and Invasive Plant Management Using Theories of Practice', in Social Practices and Dynamic Non-Humans: Nature, Materials and Technologies, ed. Cecily Maller and Yolande Strengers (Cham: Springer International Publishing, 2019), 25-46, https://doi.org/10.1007/978-3-319-92189-1_2.

172 Hatfield, Hatfield's Herbal: The Secret Society of British Plants, 152-53. 
gorse to Aotearoa for its use to humans; it also provided a reminder of homes left behind. ${ }^{173}$

In Aotearoa, with milder temperatures and free from parasites, gorse swiftly outgrew the control of those cultivating it. The climate here was so to its liking, it now flowers twice a year, rather than once as in its historical range. ${ }^{174}$ It didn't only acclimatise, it thrived. In "Valuable Ally or Invading Army? The Ambivalence of Gorse in New Zealand, 1835-1900", 175 Michael Bagge explores the to and fro of human opinion on gorse, labelling it as full of ambiguity. He concludes "It is evident that gorse defies generalisations and categorisation." ${ }^{176}$ This defiance is not unique to gorse; trying to define what is a weed is a quick route to a sore head. Even Roy's 1998 handbook fails to define what exactly a weed is, stating "Trying to reach agreement on what should be included and what missed out has been difficult." ${ }^{177}$ He does however label gorse as "New Zealand's worst weed." 178

Aotearoa as a land mass has been separated from the rest of the world for millions of years, and over $80 \%$ of the indigenous flora is found nowhere else. ${ }^{179}$ In Aotearoa a third of native species are threatened by the spread of introduced plants. ${ }^{180}$ If endemic species are lost, they can't be found anywhere else. Gorse has a complicated relationship here - in pasture abandoned to gorse, it can become a nursery plant for native seedlings. It then dies out once the regenerating natives begin blocking the sun. Swathes of Aotearoa are regenerating to native bush using this technique. ${ }^{181}$ Here new ecological entanglements emerge outside of human control.

${ }^{173}$ Cultivating connections with a previous home is by no way unique to colonisation -see Goodall, 'Rivers, Memory and Migrancy'., for examples of how different cultural groups have built connections to new landscapes

174 Roy, An Illustrated Guide to Common Weeds of New Zealand.

175 Bagge, 'Valuable Ally or Invading Army?'

176 Bagge.

177 Roy, An Illustrated Guide to Common Weeds of New Zealand, 2.

178 Roy, An Illustrated Guide to Common Weeds of New Zealand.

179 John Dawson and Rob Lucas, New Zealand's Native Trees, 2nd ed. (Nelson, New Zealand: Potton \& Burton, 2019).

${ }^{180}$ S. L. Goldson et al., 'New Zealand Pest Management: Current and Future Challenges', Journal of the Royal Society of New Zealand 45, no. 1 (2 January 2015): 31-58, https://doi.org/10.1080/03036758.2014.1000343.

181 Tein McDonald and David Lamb, 'Forest Regeneration on Hinewai Reserve, New Zealand: An Interview with Hugh Wilson', Ecological Management \& Restoration 18, no. 2 (2017): 92-102, https://doi.org/10.1111/emr.12261. 


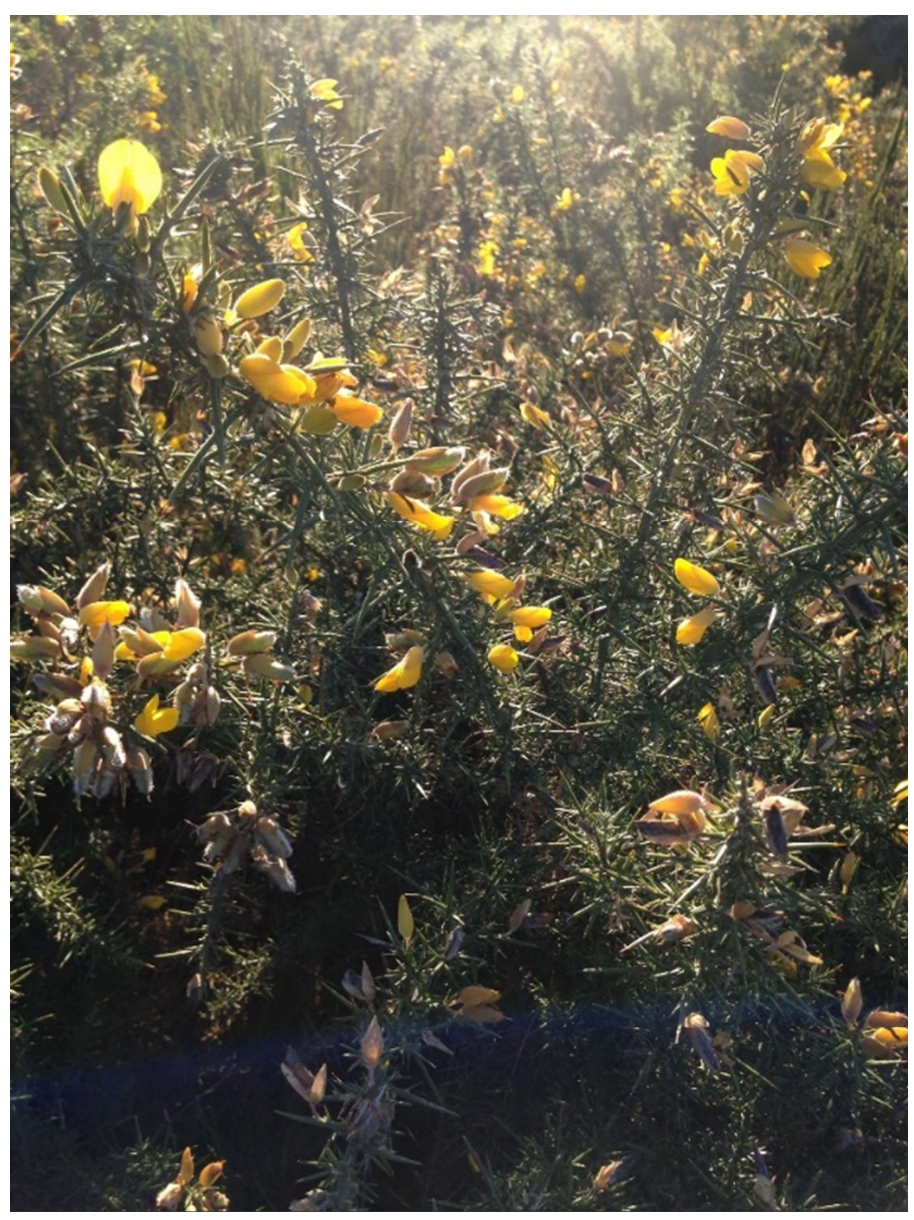

Figure 5: Gorse in its best light 
Interlude: Weeds in the Khandallah Community Garden ${ }^{182}$

\section{Jenny Kate}

We have a lot of catch-grass up there,

I can see it taunting me...

We actually don't have a whole heap of weeds

What's the one? The annoying one, I forget what it's called...

That thing there?

Oh yeah, yeah, that one.

Is that buttercup of some sort?

Yeah, it might be.

It has the yellow flower, but we don't know what it is. Yeah.

Most of the weeds here are creeping ones, that creep into the soil, but because we have planters... It's not a huge issue is it? They don't seem to get in there.

The nasturtiums go everywhere, I suppose they could be classed as a weed, but they are pretty... And they keep down other weeds. Oh yeah, we have lots of borage. Borage...

Which we've planted.

I mean we have things we contain, and they might be considered weeds...

But we actually use them. But they are part of our plan.

Wandering weeds

I met Jan a few days after weeding with Chloe and Cathy. No specific tasks had been left for us to do so we headed to an area that looked weedy and got going. Jan defines weeds for the purpose of a garden as plants "obstructing the growth of anything that you are trying to grow." Jan identified that the ground was full of couch (Elytrigia repens) and told me we needed to try and remove the whole root system to prevent re-sprouting. Repens means creep or creeping in Latin and, as with the

182 Found poem from Jenny and Kate's interview. 
buttercup, it gives a clue to the plant's nature - it sends out rhizomes underground to spread through an area. ${ }^{183} \mathrm{I}$ had seen couch before and dug it out of inconvenient spots but had simply labelled it as "grass". Instead of carefully digging around its root systems, I would carelessly tug out what was above ground and toss it to the side.

Jan has recently been transplanted from Dunedin leaving behind a beautifully flourishing garden. She was growing everything from grapes to apricots and, importantly for her, was frequently able to make meals with food harvested directly from her garden. In Dunedin, Jan had well established rhythms:

"I've always planted certain things at certain times of year. At ANZAC Day, it is broad beans, and then after that peas. Those are the first things that come ready. Then cabbage and broccoli overwinter so they don't get eaten [by caterpillars]. I grow my celery and silver beet in winter. Winter is quite a good time. Summer everything just goes nutty; you have your tomatoes and all those types of things that love sun, and pumpkins growing over summer."

In Wellington, Jan is still learning the rhythms of the warmer climate. "In Dunedin I wouldn't try and plant things at certain times of year, whereas here it seems you can sort of grow at any time of the year. I've not got used to what to plant when." She has also noticed more weeds.

Jan started gardening on Wednesday afternoons as a way to share her knowledge. "It is a community garden and it is available to everyone. People may not realise how long it takes a plant to grow and how to harvest it. They may not realise what is a plant and what is a weed." She has had one student at least: me. Watching her weed was an education. Jan has a particularly sharp spade she used to cut down the root systems of dock (Rumex obtusifolius) and loosen the soil around the couch. I'd forgotten my gloves, again, so I felt more of a hindrance than a help. As Jan confidently wielded her spade, I tentatively used a small fork to uproot the couch. Post gardening, I looked up couch and found it is "one of the best perennial weeds at regrowing rapidly following disturbance and building up food reserves in the rhizomes again, ready for the next disturbance." ${ }^{184}$ And here is one of the most crucial points.

183 Massey University, New Zealand, 'Couch', Massey University, accessed 15 January 2020, https://www.massey.ac.nz/massey/learning/colleges/college-of-sciences/clinics-and-services/weedsdatabase/couch.cfm.

${ }^{184}$ Massey University, New Zealand. 
Plants that thrive in the landscapes created by human disturbance are often those that receive the label of "weeds". ${ }^{185}$

After a satisfying hour of weeding and talking, we finished the patch we were working on and wandered down to the road. The north-east border of the garden is marked by a shelter belt and an undergrowth of flourishing green. Jan pointed out the weeds here as examples of how weeds thrive in the warmer Wellington climate in comparison to Dunedin. There's what she calls the "Wellington weed"186 and a thick mat of wandering willie (Tradescantia fluminensis) or tradescantia.

Wandering willie is one of the names used to signal tradescantia as something prone to turning up in surprise places; other terms include wandering Jew and wandering Gypsy. ${ }^{187}$ Tradescantia is originally from Brazil and arrived in Aotearoa as a garden ornamental. ${ }^{188}$ It is prevalent throughout damp sections of the Wellington town belt, including the area by the Berhampore garden. Unlike gorse, tradescantia prevents the regeneration of native seedlings. In forested areas where tradescantia has taken hold, it smothers out all other plant species and reduces invertebrate diversity, in turn affecting the food available to native birds. ${ }^{189}$

Tradescantia does not fruit in Aotearoa, meaning it can only spread through root fragments. ${ }^{190}$ Gardeners dumping their weed waste are prime suspects for its spread. ${ }^{191}$ So far, the climate has limited its spread in Aotearoa to frost-free places but, with a warming world, that could change. ${ }^{192}$ While gorse was a border escapee and plantain a stowaway, tradescantia falls into the camp of garden escapee. ${ }^{193}$ This raises

185 Anna Lowenhaupt Tsing, 'The Buck, the Bull, and the Dream of the Stag: Some Unexpected Weeds of the Anthropocene', Suomen Antropologi: Journal of the Finnish Anthropological Society 42, no. 1 (26 June 2017): 3 .

${ }^{186}$ I recognise it as either Parietaria officinalis or Parietaria judacia from my own gardening.

${ }^{187}$ Both terms heavy with religious and racial discrimination.

188 Butcher and Kelly, 'Physical and Anthropogenic Factors Predict Distribution of the Invasive Weed Tradescantia Fluminensis'.

${ }^{189}$ Richard J. Toft, Richard J. Harris, and Peter A. Williams, 'Impacts of the Weed Tradescantia Fluminensis on Insect Communities in Fragmented Forests in New Zealand', Biological Conservation 102, no. 1 (1 November 2001): 31-46, https://doi.org/10.1016/S0006-3207(01)00091-X.

${ }^{190}$ Butcher and Kelly, 'Physical and Anthropogenic Factors Predict Distribution of the Invasive Weed Tradescantia Fluminensis', 621.

191 Butcher and Kelly, 625.

192 Butcher and Kelly, 622.

193 Roy, An Illustrated Guide to Common Weeds of New Zealand, 2. 
the question, if a plant can escape a garden, are gardeners the gatekeepers? In reality, a gardener has little chance of controlling the spread of species they cultivate. The borders between a cultivated garden and the ecosystems surrounding them are porous, and the multispecies relationships we build are not static or under our control.

Yet gardeners can still be careful. In Philip Hulme's lecture Ornamental to Detrimental, he defines a weed as a "plant that has a negative impact on the economy, environment or human health" ${ }^{194}$. This is not far from Jan's definition of a weed (see page 57). Hulme's concern is what plants are currently hibernating in our gardens waiting to disrupt indigenous ecosystems? Tsing states, "Casual introductions of pests are not the problem. Most ecologies can recover from casual introductions." ${ }^{195}$ Here, invasive plants assert their place in ecosystems already disturbed by humans.

Please weed: still life

Mike Hulme, a professor of climate and culture at King's College London, considers that, "The battle against weeds is relentless and without end, but is an activity freely engaged in by the gardener and pursued resolutely." ${ }^{196}$ Hulme is talking about what can be learnt about the practice of gardening in regard to survival in the Anthropocene, yet on a lesser level the quote captures something essential about gardening practice - the motivation to keep trying despite knowledge that success shall be impermanent. My time spent at gardens this year shows that it is more complex that Hulme suggests. Some gardeners are conflicted both about what a weed is, and the activity of weeding.

194 Philip Hulme, 'Ornamental to Detrimental: The Invasion of NZ by Non-Native Plants', https://www.youtube.com/watch?v=8hhBlZe6toc.

195 Tsing, 'Earth Stalked by Man', 12.

${ }^{196}$ Hulme, Weathered, 151. 


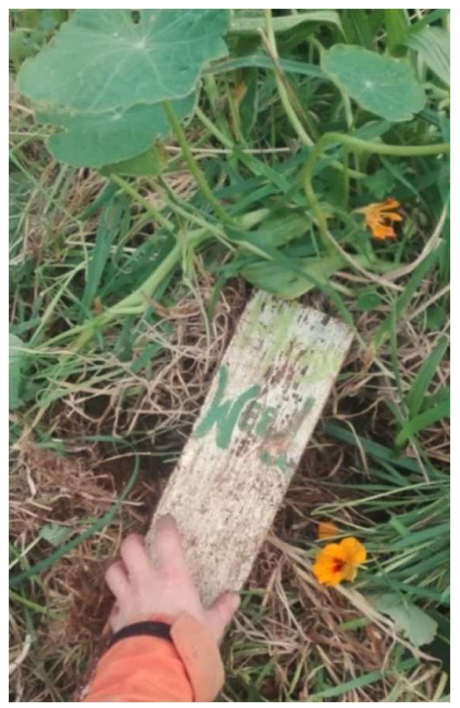

Figure 6: "Please weed" image supplied by Cbloe

Chloe chose Figure 6 to send me. It captures the moment she discovered under a pile of couch and nasturtium a sign stating, "Please weed". It made her smile, rather than frustrated. When I meet Chloe back at the garden in spring, she tells me she just finds it so funny; the worn off paint even seems like a message from the weeds to back off. She has had a transformation since the last time we met: "We really do need to be making sure there is food for the bees. This is not just about a space trying to encourage all different human interactions; it is about how we can make sure we are feeding all those other creatures too."

She had been weeding a patch of silverbeet before I arrived and struggling with the paradox, "I'm really sad weeding it. That is miner's lettuce, that is food I'm taking out of here. I can't believe I am ripping the food out so people can see the food." One of the most successful sleights-of-hand involved in gardening is the way some things become weeds and others stay as simple plants. Here, belonging becomes ambiguous and perspectives shift from person to person. Perhaps weeding is a verb that should exist without a corresponding noun? One weeds plants that have been identified as detrimental to the specific patch they are growing in. Neil Clayton, in his historiography on weeds, concluded that humans and plants labelled as weeds were often competing for the same niche. ${ }^{197}$

${ }^{197}$ Neil Clayton, 'Weeds, People and Contested Places', Environment and History 9, no. 3 (1 August 2003): 322, https://doi.org/10.3197/096734003129342863. 
That Chloe felt she needed to weed the miner's lettuce (Claytonia perfoliata syn. Montia perfoliata) had an added layer of sorrow, it is one of her favourite foods! She thinks it is very yummy and appreciates that it grows all year round: "It gives you beneficial nutrients even when there are no other vegetables growing at that time." Chloe took miner's lettuce plants from the Common Ground garden and planted them where she was living in Island Bay. She never deliberately brought it to the orchard, but it didn't used to be there, and it is now. Her theory is that it hitched a ride with seedlings she brought from home.

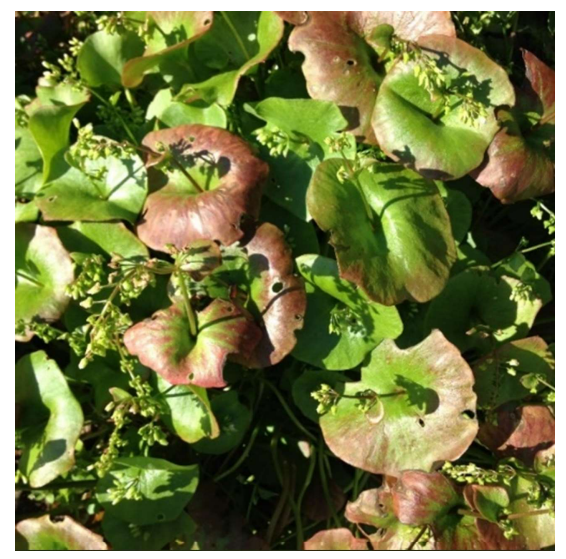

Figure 7: Miner's lettuce in flower

Claytonia perfoliata is indigenous to western North America; there ants have been observed to gather the seeds of $C$. perfoliata and spread them around the countryside. ${ }^{198}$ But humans have been important in its worldwide dispersal. The common name "miner's lettuce" refers to its consumption by the miners who flooded the gold fields of California in the $19^{\text {th }}$ Century. ${ }^{199}$ The story goes that miners travelling from California to Otago, in their continued search for gold, brought $C$. perfoliata to Aotearoa. ${ }^{200}$

Another name for C. perfoliata is "Indian's lettuce". It was harvested traditionally by indigenous people of the Californian area and up the coast. Few accessible records exist on the relationship indigenous nations had with C. perfoliata but

\footnotetext{
${ }^{198}$ Ernest Small, North American Cornucopia: Top 100 Indigenous Food Plants (CRC Press, 2013), 699.

199 Small, 697.

200 Paul Gay, 'Lettuce Give Thanks to Chinese Miners', Stuff, 31 October 2018, https://www.stuff.co.nz/southland-times/news/features/108237017/lettuce-give-thanks-to-chineseminers.
} 
it is recorded in the Western Mono dictionary as piyad $\underline{{ }^{201}}{ }^{201}$ It was eaten and used for medicinal purposes - one recorded example is that a tea made from the dried leaves could be used as a laxative. ${ }^{202}$ The loss of indigenous knowledge about companion species is indicative of what capitalism gives value to - that which is profitable.

In California fire is part of the ecology, and C. perfoliata has adapted to this disturbance regime. $C$. perfoliata has been recorded as thriving at sites that have been burnt and providing an important food source for animals returning. ${ }^{203}$ The plant does not survive the flames, but its seeds do, and they are quick to sprout. As an inconspicuous plant, it has been found to grow on "a variety of substrates including river silt, sand, gravel, road tar, loam, rock crevices, talus, and scree." ${ }^{204}$ It is a plant well prepared for a world of trouble.

Claytonia perfoliata demonstrates that one plant species may have multiple meanings - a weed in one patch, a life-saver in another. Atchison cautions against forgetting that "particular plants form relations, beyond those with people, and are consequential in the world." ${ }^{205}$ Human knowledge about our plant companions is patchy. Even what a weed is cannot be agreed on by ecologists or gardeners. This is a tension. One that requires a concession, the plants are not going back to whence they came, so what can be done to prevent further loss of plants endemic to Aotearoa? Buck invites us to "imagine another human involvement in nature, one that is not managerial or technocratic. The price, though, is giving up stories about calculability or control."206 Weeds force us to confront how our entanglements with other species are not in our control. We need to be aware of the limitations of our knowledge. In Tsing's words, "Species lists alone are not enough; we need new ways to narrate our relations with each other in changing conditions, including stories of tangled lifelines." 207

201 Rosalie Bethel et al., eds., A Dictionary of Western Mono (n.p., 1993), 122-23, http:// northforkrancheria-nsn.gov/home/ showdocument?id=29.

202 Small, North American Cornucopia, 698.

203 Robin F Matthews, 'Claytonia Perfoliata', Fire Effects Information System, 1993, https://www.fs.fed.us/database/feis/plants/forb/claper/all.html.

204 Matthews.

205 Atchison, 'Thriving in the Anthropocene'.

206 Buck, 'On the Possibilities of a Charming Anthropocene', 376.

207 Tsing, 'Dancing the Mushroom Forest'. 
It is time to acknowledge that, by cultivating and carrying with us specific plants, we cause disruption to various multispecies entanglements without knowing what the outcome will be. ${ }^{208}$ In subsequent chapters, I propose the key to navigating this landscape is care and carefulness.

An ode to Miner's lettuce:

We don't know how

it got to the garden.

It just turned up.

It can save you from scurvy.

And treat you for constipation.

It came to $\mathrm{NZ}$ with the miners,

They were after gold.

But you can't eat gold.

It is probably killed by fire.

But the evidence is inconclusive.

The seeds definitely survive the burning though.

And it thrives in the aftermath.

It grows on a "variety of substrates"

river silt, sand, gravel, road tar...

If I had any gold,

I'd bet on the miner's lettuce,

surviving the Anthropocene.

${ }^{208}$ Tsing, 'The Buck, the Bull, and the Dream of the Stag', 17. 


\section{Climate and cultivation: generalised systems and local} variations

Generalised systems, such as climate and monocultures, are compared and contrasted to localised experiences, such as weather and gardens. The essay is split into two sections. The first section looks at how gardens connect to weather in landscapes and are built into ideas of climate. The second section, through examining human connections with bananas and coffee, compares and contrasts cultivating in plantations and cultivating in gardens.

Standing in the wind

It is the wind that frames and defines Wellington's weather identity and has for at least the last two centuries. Mike Hulme, a professor of climate and culture, ${ }^{209}$ writes, "Nation-building in an imperial era also benefited from these new conceptions of climate as measurable and precise." ${ }^{210}$ The creation of new nations was tied to perceptions and measurements about their climates - the perception of New Zealand as similar in climate to Britain was crucial in attracting citizens seeking a new and better world. ${ }^{211}$ But reality didn't always meet expectations. A settler, writing to a colonial newspaper in 1864, describes Wellington's weather as "the most abominable on the face of the earth" and "wet, cold, and miserable." 212 Another resident, writing in 1865, defends the climate of Wellington: "People say it always blows in Wellington, and so it does; but it is only occasionally that inconvenience is felt." ${ }^{213}$ These differences in tolerances to daily experiences of weather are what Eliza de Vet, a cultural geographer at Wollongong University, is looking for when she considers

\footnotetext{
${ }^{209}$ Hulme, Weathered, xi.

${ }^{210}$ Hulme, 22.

211 James Beattie, 'Climate Change, Forest Conservation and Science: A Case Study of New Zealand, 1860s-1920', History of Meteorology 5 (December 2009): 1.

${ }^{212}$ Hawke's Bay Herald, 29 June 1864, Page 1

https://paperspast.natlib.govt.nz/newspapers/HBH18640629.2.4.

213 Wellington Independent, Volume XX, Issue 2205, 13 May 1865, Page 6, https://paperspast.natlib.govt.nz/newspapers/WI18650513.2.22.
} 
weather-relations. ${ }^{214}$ Buck goes further; she suggests that building connections to our environments and responding meaningfully to the challenges of the Anthropocene requires us to build relationships with the weather. ${ }^{215}$

On a cold and cloudy day in early June, I visited Tawa Community Garden. The task for the day was first creating a frame for broad beans (Vicia faba) to grow up, and then planting their seeds. Alison's hip had been playing up, so I took the task of clambering onto the raised bed. Using a hammer, as if I knew what I was doing, I jammed the stakes a satisfactory depth into the loose soil. We shared stories of garden injuries caused by gardening without gloves. Mine, two insignificant scratches from some blackberry while weeding in Berhampore, had got faintly infected and could still be seen a week later. Alison had a splinter embedded in her finger and the resulting inch-long scar. We both agreed that when gardening you need to take care.

A southerly blew down the length of the valley and both Alison and I were layered up in windbreakers. Alison told me that, while it seemed winterly, it was technically still autumn. "They say the first of June is winter, but going by temperatures we are still in autumn conditions, even though our shortest day is only three weeks away." Alison thinks of autumn as the most settled time of the year: "I know we've had a few blasts of southerlies but that can happen at any time of year." The weather is unpredictable. From Alison's observations, May 2019 had been quite warm and dry in the Tawa garden, but she says, "every year is different from season to season."

Decades ago, Alison had a garden in the Lowveld of Zimbabwe, then Rhodesia. In this garden, bananas grew like weeds. "They'd put up a shoot maybe three metres high and grow lots of bananas. Then the whole upright bit dies off and sends out whole new plants." It was a far cry from the climate of Aotearoa, and what could grow in the garden was very different. Alison recollected there being two seasons not four. It was hot and wet in summer and comparatively cool and dry in winter. The area would go brown in winter because there was no rain. She remembers that alongside the bananas, the lettuce did well during the winter and that there were mango bushes she could harvest.

Seasons frame the relationship of gardeners with their patch and the unpredictability of cultivating living matter. Hulme argues that:

214 de Vet, 'Experiencing and Responding to Everyday Weather in Darwin, Australia', 141.

215 Buck, 'On the Possibilities of a Charming Anthropocene'. 375 
Beyond scientific analysis, climate may also be apprehended intuitively, as a tacit idea held in the human mind or in social memory of what the weather of a place 'should be' at a certain time of year. ${ }^{216}$

Hulme ties climate back to human experience of weather, drawing attention to how weather influences culture, be it through celebrations of spring blossoms or buying windbreakers. ${ }^{217}$

Alison keeps track of the seasons, but she also responds to daily weather. She prefers a calm sunny day for gardening, one that is not too warm. Alison tried planting by the moon, but eventually abandoned it. "I couldn't figure out if it was making any difference and I decided that it was far more important how happy I was to go outside." Recently, Alison had headed to the garden but "as soon I got there the fog came down and then it rained." Rather than get wet, she decided against gardening that day. As Alison's house is just a short walk from the community garden she can easily pop out, then decide to head home if the weather is not amenable. By the time we had built the broad bean frame, we were both feeling the wind chill. I was happy to accept her suggestion to finish the conversation at her house.

Alison does not only think about the weather in relation to herself, she also considers the needs of the plants. While wind and rain restrict when she wishes to be in the garden, she considers soil temperature most important for cultivated crops. At Alison's house I'm shown the efforts she has made to protect her plants from wind, including improvised barriers to deflect the breezes' impact. Alison doesn't see the wind as all bad for the garden though. She has a theory about the weather influencing pest visits: "Maybe sometimes the wind is in our favour. On a windy day in summer you don't get the white butterflies."

\section{On a good day}

Seated in the old clubrooms at Innermost Gardens, I clasped a cup of kawakawa tea in my hands to try and keep warm. I asked Chris what she thought of the Wellington

\footnotetext{
216 Mike Hulme, 'Climate', Environmental Humanities 6, no. 1 (1 May 2015): 177, https://doi.org/10.1215/22011919-3615952.

${ }^{217}$ Hulme, 176.
} 
weather and she summed it up with a laugh, "People don't live in Wellington because of the weather." While the northerlies get to her, she still has a fondness for some wild weather, "I quite like the storms, the southerlies, it brings the next day the blue sky and that breath of fresh air... we've flushed the system out and everything is good again."

Chris grew up in Auckland but left when she was 18. I asked her to compare the climates of the two North Island cities and she tells me, "I feel like Wellington is feeling a bit like Auckland used to and Auckland is feeling a bit more tropical than it ever used to. My sister lives in Pukekohe and they didn't have rain from Boxing Day till the end of March. She was showing me pictures of sheep paddocks that were bone dry." Chris's concern is that this area is the food bowl of Auckland and it is not just drought that affects it: "My mum the winter before couldn't get on to the golf course because it was too wet. When I was at school you'd always take your raincoat to school because you never knew when it would rain but it would be a shower and that was it. It's more extreme now."

The impact of climate change is something that scientists are working very hard to predict. Scenarios are run under different possible predictions for almost any aspect of climate you could imagine and measure. In Wellington, under all modelled situations, predictions suggest increasing temperatures will result in more "hot days" and fewer frosts. ${ }^{218}$

Hulme proposes that understanding how climate change may affect us is dependent on first understanding our cultural relationship to climate. He acknowledges the scientific definition of climate but considers that, "They too easily maintain a false separation between a physical world (to be understood through scientific inquiry) and an imaginative one (to be understood through meaningful narratives or human practices)." 219 These observations from the Wellington gardeners that climate change might be happening already are human narratives rather than scientific. This is significant - if we accept that the stories we tell are as important as the science we do.

Observations of weather have been built upon each other to become observations of long-term cycles. Climate may well be indescribable and, for all the modelling in the world, unpredictable, but the weather is something we experience and

${ }^{218}$ Petra Pearce et al., 'Climate Change and Variability - Wellington Region' (National Institute of Water \& Atmospheric Research Ltd, June 2019).

${ }^{219}$ Hulme, 'Climate', 175-76. 
thus can describe. These physical experiences of environment and weather are crucial in creating imaginative tools for thinking about a changing climate and what experiencing it may be like, both locally and globally.

Gardening in Wellington means considering which direction the prevailing wind comes from. The community gardens I visit are all in high wind zones. ${ }^{220}$ To address this, they have strategic planting to act as windbreaks. In three of the four gardens, feijoa trees are used as hedging. At Innermost Gardens, they mark the boundary between the bowling club and the gardens - the idea is that as they mature they will provide wind protection and produce food. Feijoas originate from South America and they are well-loved in New Zealand. Feijoas cannot be easily transported, are hard to store and are somewhat of an acquired taste. While you can buy them in the season between March and June, they are also widely bartered; one feijoa hedge can provide overwhelming amounts of fruit. So, using them as a windbreak is a winwin scenario, providing both food and shelter. ${ }^{221}$

In Tawa, they do not use chemicals and they've never had a large-scale invasion of any insect. They feel they have achieved this through careful seasonal planting. However, Alison predicts if they planted brassicas in summer, they would be decimated by the white butterflies. She sees them in the Tawa garden in the warmer months. To avoid losing crops, Tawa's gardeners carefully wait until the weather has cooled before planting out their cabbages and broccoli. Alison muses that this has been moving later in the year, "What I do notice is it's a bit of luck to guessing when it gets cold enough for the white butterfly to disappear. I think it is shifting."

Looking towards a warmer world, Alison considers that pests and diseases not currently present in Wellington may well spread into this region. Psyllids and fruit flies are two examples she knows are in the country but are not yet bothering the Tawa garden. Responding to new species in a warmer world will be about, in Alison's words, "changing what we grow, season by season, and being warned" about the arrival of unwanted species.

\footnotetext{
${ }^{220}$ The Berhampore and Khandallah gardens are in a high wind zone. Innermost is very high. Coronation park is medium (the lowest on the map). See 'Wind Zones - LocalMaps', accessed 12 February 2020, https://gis.wcc.govt.nz/LocalMaps/Viewer/?map=50f1b8e3d8594e3098b65d698a7713a4.

221 But the wind is not a sterile force. The Myrtle Rust fungus (Austropuccinia psidii) arrived in Aotearoa in 2017 and one of the plants at risk is the feijoa.
} 
A thoughtful gardener works with rhythms. This means considering the seasons, the prevailing wind direction, how much sun a patch gets, or the likely rainfall. But a gardener also tries to work around rhythms. A careful gardener plans watering schedules over summer, plants windbreaks or builds greenhouses to increase growing temperatures. It is a careful balance - a sleight of hand if you will. It requires consideration of environmental limits, not to work against but to consider how, with care, you can push them out.

How do we define gardening as different to those other forms of cultivation that cause damage to the world? For me the crucial difference here is caring-caring for ourselves, other species and the land we are cultivating. But how do these differences materially express themselves? And what connections are present? To talk about community gardens in the Anthropocene means to talk about other ways we cultivate.

\section{Going bananas}

At one of the Innermost working bees, I was delegated the task of planting some pepino (Solanum muricatum). When I asked how, I got a rather bemused response "By digging a hole." So, I picked up the pepino and a sturdy looking spade and headed to the most sheltered and sunny corner of Innermost Gardens aka Subtropical Alley. This is the area where mushrooms were used to decontaminate the soil and it was not like digging in the soil I am used to. I benefited from years of work put in by the community gardeners. It was a pleasure to dig holes here, unlike the clay soils I have in my own garden.

Subtropical Alley contains a host of plants unusual in the Wellington region; avocado (Persea americana), figs (Ficus carica), guava (species unknown), pepinos (Solanum muricatum) and two bananas (Musa spp.) of a hardier variety than commonly grown commercially. As someone who has lived through the freezing southerlies of Wellington, the idea of a subtropical garden bed here seems risky but, with care and consideration, the gardeners are committed to this experiment. They have piled layers and layers of compost on the ground, fed them comfrey tea bi-weekly and nestled the 
extra-sensitive plants inside frost and wind cloth. It remains to be seen whether the plants will thrive and survive but, if they don't, it won't be due to carelessness.

Hulme observes that: "Gardening becomes a metaphor for caring and for making mindfully and responsibly, virtues that are needed for composition in the Anthropocene." 222 Yet, Hulme cautions this approach, as methods of human cultivation are not by default innocuous, "Over countless generations they have also yielded agricultures, horticultures, aquacultures, silvicultures and permacultures." ${ }^{223}$ Of course he is right - humans have cultivated other species in any way that we have been able to imagine and then technically achieve. ${ }^{224}$ But it also obscures crucial differences in human practices. We are not comparing apples with oranges. The impact of a banana plantation managed with intensive pesticides is not the same as two bananaplants growing in a community garden.

Bananas are a poster child for plantations and, as an example, can illustrate those differences further. Bananas are popular in New Zealand, but we are almost solely dependent on international trade to get them. Each year we import around $18 \mathrm{~kg}$ of bananas per person. The price of these bananas follows a "weekly rhythm with strong seasonal fluctuations." 225 This means a tropical storm in Ecuador or a drought in the Philippines might lead to a hike in prices of bananas at the local Pak n' Save supermarket. Forty percent of cultivation takes place on plantations of more than 100 hectares run by large global corporations. ${ }^{226}$

In many of these plantations, bananas are cultivated at the expense of humans and their local environments. In the 1950s the emergence of the Panama disease (Fusarium oxysporum) resulted in the first commercial species of banana, the Gros Michel, becoming commercially unviable. Its commercial replacement, the Cavendish, was more resistant to this disease but now another fungus, the Black Sigatoka (Pseudocercospora fijiensis) threatens the industry. ${ }^{227}$ To keep it at bay, plantations employ

\footnotetext{
222 Hulme, Weathered, 151.

${ }^{223}$ Hulme, 151.

${ }^{224}$ Consider hydroponics where plants are cultivated without soil or the concept of meat cultivated in laboratories.

225 The Bureau for the Appraisal of Societal Impacts and Costs, 'New Zealand Bananas: The Big Squeeze' (Fairtrade Australia and New Zealand, 2017).

226 The Bureau for the Appraisal of Societal Impacts and Costs.

${ }^{227}$ Gert HJ Kema, 'One Super-Susceptible Clone, a Versatile Fungus and Failing Fungicides - Black Sigatoka and Banana', Plos Biologue (blog), 12 August 2016, http://blogs.plos.org/biologue/?p=10284.
} 
huge loads of fungicides. ${ }^{228}$ In Ecuador, the world's largest exporter of bananas, waterways, farmlands and houses near banana plantations were found to be "impregnated" with agricultural chemicals. ${ }^{229}$ The workers on these plantations experience a variety of related ill-health; burning eyes, insomnia and dizziness to list a few. ${ }^{230}$

Tsing recognises that plantations are only one type of cultivation, describing mixed cropping in Indonesian Borneo:

Rice, bananas, taro, sweet potatoes, sugarcane, palms, and fruit trees mingled; farmers needed to attend to the varied schedules of maturation of each of these crops. These rhythms were their relation to human harvests; if we add other relations, for example, to pollinators or other plants, rhythms multiply. The polyphonic assemblage is the gathering of these rhythms, as they result from world-making projects, human and not human. ${ }^{231}$

The food forest of Innermost Gardens reflects these principles, of care, attention and rhythms. The predominant methods employed in banana plantations do not.

So wise am I
Musa sapientum
Muse of the wise
Or a shrewd fruit
Homo sapiens
The wise man
Eats bananas
(Or looks at bananas?)
(What exactly does a muse do?)
To get more wise
Think about
How to categorise
Our friends

\footnotetext{
228 Timothy L. Friesen, 'Combating the Sigatoka Disease Complex on Banana', PLOS Genetics 12, no. 8 (11 August 2016): e1006234, https://doi.org/10.1371/journal.pgen.1006234.

${ }^{229}$ The Bureau for the Appraisal of Societal Impacts and Costs, 'New Zealand Bananas: The Big Squeeze', 10.

230 The Bureau for the Appraisal of Societal Impacts and Costs, 10.

231 Tsing, The Mushroom at the End of the World, 27.
} 
Sweet versus savoury?

To cook or not to cook?

Yellow or blue?

(I know my colours)

Come up with a catch phrase

Now that's shrewd

Linnaeus was-a-dingus

Enjoy eternal referencing

Smells like coffee

There are similarities between coffee and petrol. Petrol is dark and oily and smells strong. Coffee (Coffea sp.) is dark and oily and smells strong. Petrol gets people going. Coffee keeps people going. Petrol is something that requires imagination to live without. Coffee is something that requires imagination to even imagine living without it. They both come from plants, though we can forget that petrol is "fossilized plant matter." ${ }^{232}$ The most important difference is that drinking petrol can kill you, and it will be painful. Drinking coffee won't kill you, but it might be painful to give it up. I don't make this comparison lightly; they are the two most commonly traded commodities of the Anthropocene. Two forms of black gold that fuel us through the compulsory busy-ness of this era. ${ }^{233}$ The fate of coffee is tangled up with petrol. How fast, and how much petrol we burn will determine which carbon emissions path we are on. The higher the carbon emissions, the more we risk losing the patches where coffee can grow. ${ }^{234}$

I've only ever met one coffee plant. It is a small dusty plant on display in a Wellington café. Sometimes I dust the leaves back to a shiny green, but I have no idea whether it appreciates it or not. It is the cherry of the coffee plant that gets processed

\footnotetext{
232 Jennifer Mae Hamilton, 'Gardening out of the Anthropocene: Creating Different Relations between Humans and Edible Plants in Sydney', in Covert Plants: Vegetal Consciousness and Agency in an Anthropocentric World, ed. Prudence Gibson and Baylee Brits (Santa Barbara, CA: punctum books, 2018), 222.

${ }^{233}$ Aaron P. Davis et al., 'The Impact of Climate Change on Indigenous Arabica Coffee (Coffea Arabica): Predicting Future Trends and Identifying Priorities', PLOS ONE 7, no. 11 (7 November 2012): 1, https://doi.org/10.1371/journal.pone.0047981.

${ }^{234}$ Christian Bunn et al., 'A Bitter Cup: Climate Change Profile of Global Production of Arabica and Robusta Coffee', Climatic Change 129, no. 1 (1 March 2015): 89-101, https://doi.org/10.1007/s10584014-1306-x.
} 
into the coffee bean. The coffee industry is a prolific producer of waste products. ${ }^{235}$ Mostly these are invisible in the consuming countries, the two main waste products, coffee pulp and cherry husk, remain in the local landscapes where coffee is grown. ${ }^{236}$ Coffee pulp can be composted but more often is directly applied to soils, to the detriment of soil ecosystems. An added risk is that Aspergillus ochraceus can flourish in this substrate, a mould that produces a toxin possibly carcinogenic to humans and other animals. ${ }^{237}$

Closer to home in Aotearoa, two waste products are commonly produced at the roasting and drinking stage; spent coffee grounds and silverskin. I was surprised to find that Tawa Community Garden smells like coffee. As Alison explained to me, the compost contains coffee grounds donated from the local supermarket; combined with carbon and garden waste, the coffee moves through a trio of black bins. Here they pass through the various states of decomposition and transformation into compost. I crumbled some coffee grounds between my gloved hands. Still moulded in the shape of the coffee stamper, they were grainy, damp and got stuck under my fingernails. The smell was sour, a tangier version of coffee, and there were small clumps of white mould along the edges. Having read about the powers of $A$. ochraceus, I can only hope this mould is unrelated.

In Tawa, and in the other community gardens, the waste products of coffee have been integrated into growing systems. The spent coffee grounds used in the Tawa compost heaps are what a coffee drinker will be most familiar with, simply what you get at the bottom of your plunger after the production of soluble coffee. The silverskin is produced through the roasting process. At Innermost Gardens, it is used to add a carbon layer to the compost when households dump their food waste. These are dry and so insubstantial that when you run your hands through them the sensation is only the suggestion of texture. To me it smells like a combination of hay with only a faint quality of coffee. For the community gardens, the re-use of coffee grounds and silverskin serves as a free source of nutrition for their compost piles. The components of the coffee industry are re-used in these spots, diverting waste from other end of life

\footnotetext{
${ }^{235}$ Kulandaivelu Velmourougane and Rajeev Bhat, 'Sustainability Challenges in the Coffee Plantation Sector', in Sustainability Challenges in the Agrofood Sector (John Wiley \& Sons, Ltd, 2017), 630-31, https://doi.org/10.1002/9781119072737.ch26.

236 Velmourougane and Bhat, 630-31.

237 Velmourougane and Bhat, 629.
} 
outcomes. The use of coffee grounds, coffee sacks and coffee silverskin links these community gardens to the wider economy of Wellington and the global commodity trade.

The relationship between humanity and coffee goes back to at least 500 A.D. with legends of the Oromo people speaking of a goatherd discovering the plant. ${ }^{238}$ The most consumed species, Coffea arabica, ${ }^{239}$ thrives as an understorey plant in equatorial montane forests. It has spread from the highlands of Ethiopia to encircle the world. There is no denying that coffee is an influential companion species. Its global rise, and predicted fall, follows the path of human migration around the world. In every cup we consume, we are partaking in the flow of capital and an extraction industry dependent on one plant family.

Coffee growing illustrates how human cultivation techniques can lead to the rise of unwanted companions and, furthermore, the precarious situation the Anthropocene puts these companions in. The cultivation of coffee in plantations, as with bananas and countless other species, has cultivated coffee-specific diseases and pests. Coffee rust (Hemileia vastatrix), Fusarium bark disease, coffee berry disease (Colletotrichum coffeanum), shot hole borer (Xylosandrus compactus), black rot (Koleroga noxia)... the list of anti-companions goes on. ${ }^{240}$ Coffee rust has already brought the coffee industry to a close in some countries; an early example is the arrival of the disease in Ceylon (now Sri Lanka). ${ }^{241}$

Coffee is particular about where it grows, unfortunately the patches required for successful coffee plantations have a grim forecast. By the middle of the $21^{\text {st }}$ century, under all emissions scenarios, land suitable for growing coffee will have been reduced by around $50 \% .{ }^{242}$ Coffee plantations are grown for the long term: a site being

\footnotetext{
${ }^{238}$ Adriana Farah, COFFEE: Production, Quality and Chemistry. (LONDON: ROYAL SOC OF CHEMISTRY, 2019), 9.

239 Two coffee species are commonly consumed, Coffea arabica (Arabica) and Coffea canephora var robusta (Robusta). It was thought that Robusta would withstand predicted climate change to a greater extent, but recent analysis shows that it is also vulnerable. C. Arabica is the most consumed and is the byproduct that will be found in Wellington coffee shops. When I discuss coffee in this essay I am referring to C. arabica rather than the whole genus see Bunn et al., 'A Bitter Cup', 90.

240 J.M. Waller, M. Bigger, and R.J. Hillocks, Coffee Pests, Diseases and Their Management (Wallingford, UNITED KINGDOM: CABI, 2007), 290, http://ebookcentral.proquest.com/lib/vuw/detail.action?docID=315092.

241 Waller, Bigger, and Hillocks, 170.

${ }^{242}$ Christian Bunn et al., 'Multiclass Classification of Agro-Ecological Zones for Arabica Coffee: An Improved Understanding of the Impacts of Climate Change', PLOS ONE 10, no. 10 (27 October 2015): e0140490, https://doi.org/10.1371/journal.pone.0140490.
} 
planted now should still be producing in the mid to late $21^{\text {st }}$ century. This means that future climate is already relevant to our coffee companion species. Anthropogenic climate change will likely "influence the incidence and severity of coffee diseases because of the close linkage with the environment." Small increases in temperature will encourage rust at high elevations, drought conditions will increase plant stress and make them more susceptible to diseases too. ${ }^{243}$ One hundred million people's livelihoods are derived from coffee. ${ }^{244}$ The result of coffee's sensitivity to climate will be both political and economic.

Coffee does best when grown as part of wider forest ecologies - 'shade grown' coffee tastes better and allows wider entanglements of flora and fauna to co-exist. ${ }^{245}$ The forest canopy provides protection from extremes in weather, wind and hail are damaging to crops. It also reduces the need for weed management and soil erosion associated with plantations. ${ }^{246}$ These are closer to the "polyphonic assemblage" that Tsing describes. ${ }^{247}$ Turning towards cultivation for coffee in this way won't stop the climate changing, but it offers an opportunity for recreating more complex entanglements and a chance for other species to flourish alongside coffee.

Chloe and I discussed gardening versus agriculture at one of my visits to the Berhampore Orchard. In her thinking, "Modern agriculture is about being really productive, whereas gardening is about learning. You can be more experimental as people aren't dependent on the outcomes of a community garden." This captures an important point, unlike the community gardens where food supplements diets, the plantations, where bananas and coffee grow, are entangled with the livelihoods of millions of people. Capitalism has commodified food to the point that access to food is determined by profitability. What a farmer grows is motivated by global demands. Diversity of crops are often overlooked in favour of those that can be on-sold.

Plantations are contradictions, they replicate generality, but they cannot escape from locality. ${ }^{248}$ The plants of the plantations are still entangled with these localities

\footnotetext{
${ }^{243}$ Chhristian Bunn et al.

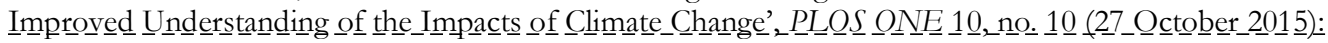
e 0140490, https: L/_doi.org/10.1371/ journal.pone.01404900.

${ }^{244}$ Bunn et al., 'A Bitter Cup', 89.

${ }^{245}$ Velmourougane and Bhat, 'Sustainability Challenges in the Coffee Plantation Sector', 632.

246 Waller, Bigger, and Hillocks, Coffee Pests, Diseases and Their Management, 313.

${ }^{247}$ Tsing, The Mushroom at the End of the World, 201.

${ }^{248}$ Tsing, 'Earth Stalked by Man', 5.
} 
and the weathering experienced there. Every plantation is still a place and ecosystems are never that simple. Remove one strand, encourage another - before you know it you've tied yourself into a knot. ${ }^{249}$ In community gardens locally grown food is grown outside of global markets. These gardens localise production and the lifecycle of these plants. Yet they are not completely removed from global systems, as seen by the surfeit of coffee in their composts.

Coffee

When I first drank a cup of coffee, I felt my brain go itchy.

I felt as though

I was going too fast for the world, or the world was going too fast for me.

Someone had pressed the fast-forward button, And I couldn't turn it off.

The feeling in my stomach told me, the world was ending at high-speed and I had no power except to watch.

249 Tsing, 5. 


\section{Say it with beans: growing food and reciprocity}

How and what we eat is a matter of deep complexity. ${ }^{250}$ Community gardens provide a place to connect with our food and a way for the gardeners to take a small step outside of capitalist food markets. "Reciprocal capture" is a phrase coined by Isabelle Stengers to describe the relationships between species that emerge over generations, illustrated by van Dooren et al through the connection between a flower and the bee that pollinates it. "As such, they do not just happen to meet each other, this bee and this flower; rather, their relationship emerges from coevolutionary histories, from rich processes of cobecoming." ${ }^{251}$ Reciprocal capture can be seen in the relationship between humans and the species that offer us sustenance. A further layer is added by considering the landscapes these interactions exist within.

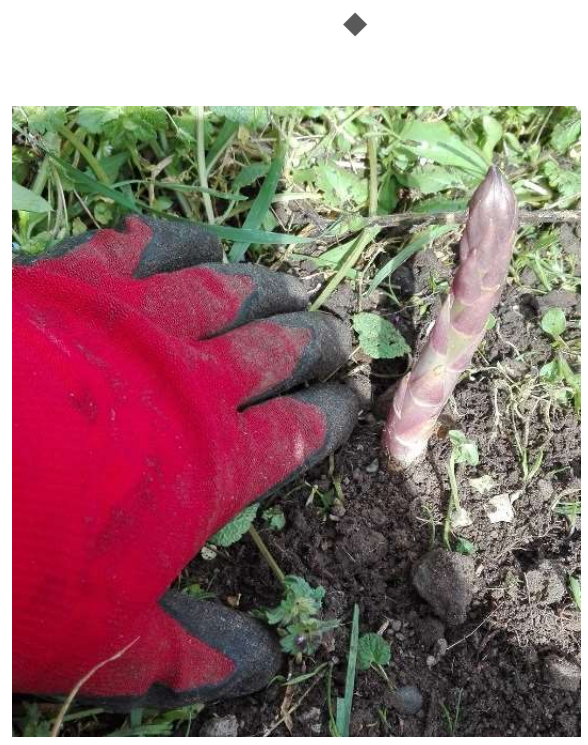

Figure 8: Finding food, image supplied by Chloe

By my spring visit to the Berhampore garden, the asparagus had come up. Jan encouraged me to try it straight from the garden, the soil freshly brushed off. It was delicious, crunchy and sweet; asparagus like I'd never tasted before. Jan loves the connection when you harvest and eat your own food: "My family gets very sick of me

${ }^{250}$ Rebecca Kiddle et al., 'E Hoa Ma, Ina Te Ora o Te Tangata (My Friends, This Is the Essence of Life): Meal-Making as a Pedagogical Tool for Learning about Food Politics', Policy Futures in Education 17, no. 7 (1 October 2019): 17, https://doi.org/10.1177/1478210318819209.

251 van Dooren, Kirksey, and Münster, 'Multispecies Studies Cultivating Arts of Attentiveness'. 
saying 'this is just from the garden.' They get tired of that!' But this doesn't diminish the satisfaction Jan gets from harvesting her own food for eating. Jan explained to me on our first meeting how to harvest a celery plant: "Instead of chopping the centre out you just pick one stalk around the edge. That celery can last all winter and does not go to seed, if you don't over-harvest it."

For many of us, our interactions with our food begins long after the harvest, ${ }^{252}$ in locations far from the landscapes where they grew (think of bananas or coffee). Jan is very conscious about what food she is consuming; she's concerned by the distance that something might have travelled and the amount of plastic packaging. "There is just something wrong about going to the supermarket and buying something that isn't actually currently growing. If you grow your own, you know what is in season."

Without a home garden in Wellington, Jan has two garden plots at other community gardens in addition to her involvement at Berhampore Island Bay Community Orchard. She's not achieving the dream of only eating food she's grown but, "I do always buy in season, I never buy things that come on a plane, I do what I can to eat what is in my garden..." Jan works, within her power, to remain in connection to the food she consumes.

Heather Goodall, an environmental historian, points out that "eating is one of the ways that humans remain directly in contact with their environment, wherever they are." ${ }^{253}$ For Jan, it is more than having a place to grow her own food. She sees the connection from harvest, to pantry, to plate and then the scraps returning to the compost heap. "It's knowing that there is a place to give your compost back to the ground. I hate putting food scraps in the rubbish bin." She acknowledges that reducing food waste is a bit about know-how, "If you have ever been very poor you don't like to throw food out. I always make things into soup or do something with them even if they do look kind of floppy. It is really important, but it's just been lost, and people's lives are so busy, if they are working fulltime. It is a big challenge."

Imagining the garden in the future Jan immediately said, "It would be cool to be able to associate the garden with a kitchen. That is my favourite thing." She imagines an octagonal house in the middle of the garden, somewhere you could boil the jug and have a cup of tea or have the garden meetings. Maybe have a picnic or

\footnotetext{
${ }^{252}$ Hamilton, 'Gardening out of the Anthropocene: Creating Different Relations between Humans and Edible Plants in Sydney', 222.

253 Goodall, 'Rivers, Memory and Migrancy', 32.
} 
two. She points at a half-built tree house and laughs that maybe that will be finished and, in 10 years, they might even have added a slide! Then she returned to the idea of the kitchen - with that they could run a gardening club where you have the kids gardening and then eating their harvest. In this imagined future, the children would learn the arts of tending to plants that would provide them nourishment in return. An early lesson in the arts of reciprocity.

In "Gardening out the Anthropocene", Jennifer Hamilton looks at a series of "edible art gardens" in Sydney city. She reminds us that gardens are intertwined with the wider landscapes and "contemporary moment" 254 In Aotearoa, landscapes continue to transform. "One billion trees" is underway, a massive tree-planting programme, designed to give us more breathing space on our warming planet. ${ }^{255}$ The news cycle has been dominated by stories of farms being converted into pine plantations and market gardens being subdivided. Both are putting pressure on land that has been traditionally devoted to food cultivation. Jan touched on this, "I think it is a shame if we are selling all our arable land to forestry. We don't want to get rid of all our growing land, that is going to be important." It reminds me of how Chris, from Innermost Gardens, grew up on the volcanic soil of the Auckland isthmus, surrounded by farms and market gardens. She told me how the land has been subsumed into the Auckland airport or industrial use - one patch now has a plastic-making factory on it. Both Jan and Chris, as community gardeners, had wider concerns about where our food comes from. Realistic that growing enough food to sustain a diet was out of the reach of many people, due to lack of access to land or time, their concern extended to the pressures on wider food producing landscapes.

For Chloe, her gardening relates to wider landscapes too and the need for food activism. It started when she learnt that Monsanto was developing seeds that were only viable for one season and locked farmers into a cycle of dependency. She realised, "Holy shit, we might actually be out of control of growing our own food!" Chloe wanted to enable others to connect their food to where it grows. Claire Nettle's Community Gardening as Social Action explores the ways activism is present in a number

${ }^{254}$ Hamilton, 'Gardening out of the Anthropocene: Creating Different Relations between Humans and Edible Plants in Sydney', 229.

${ }^{255}$ Ministry for Primary Industries, 'About the One Billion Trees Programme |', accessed 6 February 2020, https://www.teururakau.govt.nz/funding-and-programmes/forestry/one-billion-treesprogramme/about-the-one-billion-trees-programme/. 
of Australian community gardens. ${ }^{256}$ Some gardeners, like Chloe, identified the disconnect between consumption and production of food "as a fundamental part of the problem of food insecurity." ${ }^{257}$ Chloe told me she wanted people to know what a carrot looks like when it's pulled from the ground, and that imperfect kai is still edible. Here the motivation is to bring people back into having an intimate understanding of their food.

The search for new plants, and associated uses for them, has been an important driver of imperial exploration. ${ }^{258}$ But first encounters and explorations of new lands also, in some cases, brought reciprocity through food. In "Plumpinon", (In Multispecies Salon), Lindsay Kelley considers the way plants are purposed towards human need and power structures through the example of the piñon (Pinus subsection Cembroides), the source of pine nuts. ${ }^{259}$ A piñon tree can have a lifetime equivalent to many human generations; they have been known to live for 700 years. They do not begin producing the highly nutritious seeds until they reach 25 years old and do not produce fully until 75 years. Kelley examines the history of piñon as a "starvation food" 260 and its entanglements with the colonial history of New Mexico through the frame of reciprocal capture.

Cadeza de Vaca and his slave Esteban were the first European and African, respectively, to pass through the American Southeast. ${ }^{261}$ They survived by eating piñon as provided by the local peoples: a later group of explorers refused to exchange with the indigenous people and, as a result, starved to death. ${ }^{262}$ Kelley describes this as being taught "how to eat this landscape" and defines it as an expression of

256 Claire Nettle, Community Gardening as Social Action (Routledge, 2016), https://doi.org/10.4324/9781315572970.

257 Nettle, 95.

${ }^{258}$ Londa L. Schiebinger, Plants and Empire: Colonial Bioprospecting in the Atlantic World (Cambridge, Mass: Harvard University Press, 2004), 6-7.

${ }^{259}$ Kelley, 'Plumpiñon', 169.

${ }^{260}$ The term starvation food applies to those foods that could sustain a community through lean times including the crops that had significant harvests and did not spoil quickly. In the world of seasonal availability and no international trade these foods often got groups of people through the winter. Kelley, 162-63.

${ }^{261}$ Kelley, 168.

${ }^{262}$ Kelley, 168-70. 
reciprocity. ${ }^{263}$ Similar stories can be found closer to home; in Australia, the European colonists refused to use the food the country offered. ${ }^{264}$ The narrative of a barren country waiting for civilisation belies the fact that human occupation of the Australian continent stretches back long beyond western memory. ${ }^{265}$ Kelley highlights how it is possible to be in a landscape and fail to recognise the "food sources all around". ${ }^{266}$ What we eat is in the end a deeply intimate matter, an entanglement of life and death.

In Aotearoa, we have stories of successful and failed reciprocity, like Kelley recounts in relation to the piñon. Buchanan has recounted the story of Parihaka in Ko Taranaki te Maunga. In response to a passive resistance movement seeking to retain a remnant of ancestral land, the New Zealand Crown forces refused to respond in kind. It was a failure of reciprocity. Cultivated land was deliberately damaged - if you destroy a harvest, you hurt the people dependent on it. On the day Parihaka was invaded, the force was welcomed with children singing and freshly baked bread. ${ }^{267}$ In response, they received violence and destruction. ${ }^{268}$

What we grow connects us with our wider histories. The history of vegetable gardens in Aotearoa is therefore a history of our eating culture and a history of morethan-human relationships. In 1,000 Years of Gardening in New Zealand Helen Leach looks at the legacy of gardening from the arrival of the Polynesian explorers to the late $20^{\text {th }}$ Century. ${ }^{269}$ The community gardens reflect patches of human history in the plants they cultivate. The majority of these plants came with humans, rather than being here when we arrived. For example, kūmara and potatoes have their roots in the Americas and travelled to Aotearoa via Polynesia and Europe respectively.

Papakura described the process of kūmara harvest in her iwi, retelling the story of how Rongonui-Maui and his wife Pani-Tinikau gave birth to the various varieties of

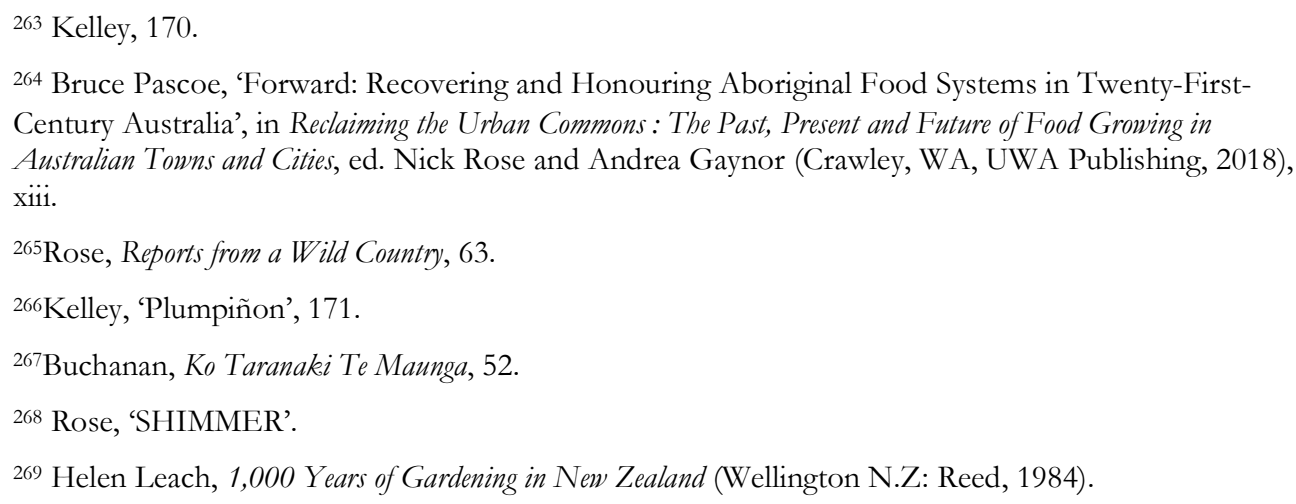


kūmara. ${ }^{270}$ The story of kūmara varies from iwi to iwi but for Hutchings it reinforces how kūmara connects Māori to their past and their Polynesian whakapapa. ${ }^{271}$ Their Polynesian ancestors transported various plant cultivars with them to Aotearoa. Not all these plants survived the journey, and not all the species that arrived could thrive in this new climate. Kūmara (Ipomoea batatas) was one that did; it requires a shorter growing season than other Pacific food crops and became one of the most important food sources for Māori. ${ }^{272}$

Potatoes (Solanum tuberosum) arrived in Aotearoa with the first European ships, and iwi were swift to adopt this new food. As a result, kūmara was displaced as the predominant crop. ${ }^{273}$ Leach suggests that the adoption by Māori of potatoes was due to their familiarity with kūmara. In contrast, Europeans had been reluctant to adopt potatoes as a food source on its introduction from the Americas in the 1500s. Instead of seeing a potential meal, it was viewed in relation to black and deadly nightshade $(S$. nigrum and Atropa belladonna), two plants with a long history of poisoning humans and animals. $^{274}$

With the passing of time this attitude has faded. Chloe spoke to me enthusiastically about the benefits of potatoes, her favourite vegetable. It is not so much the taste, but the social interactions they enable - "I guess it is the social part of hot chips, they're always a good time...." She was pleased to see them planted in the garden, though she was not sure by whom. Jan told me later that her husband, who works as a chaplain at the next-door council flats, had sown the potatoes with a group of the tenants. The potatoes had been donated from Kaibosh, a Wellington food rescue organisation. ${ }^{275}$ Jan was a bit unsure if they'd successfully grow but thought it was worth trying. I think of this as an example of food circulating outside of traditional capital routes.

Chloe is interested in growing kūmara at the Berhampore gardens. "I would love to do a kūmara patch for Parihaka. I will need to do more research, but I think it is the cultivated food of Rongo-Mā-Tāne - they are also the atua of peace. I want to

\footnotetext{
270 Papakura, The Old-Time Maori, 175-77.

${ }^{271}$ Hutchings, Te Mabi Māra Hua Parakore, 210.

${ }^{272}$ Leach, 1,000 Years of Gardening in New Zealand, 58.

273 Hutchings, Te Mabi Māra Hua Parakore, 210.

${ }^{274}$ Leach, 1,000 Years of Gardening in New Zealand, 125.

275 see https://www.kaibosh.org.nz/
} 
plant it not for the taste but the significance of the vegetable." Chloe states that her reason for gardening is activism, so I'm interested to know if she links it to decolonisation. From her perspective, the transformation of the hillside from part of a golf course into a community garden is a form of decolonisation - turning a landscape that was used by twelve people for an elitist sport into a landscape that welcomes all.

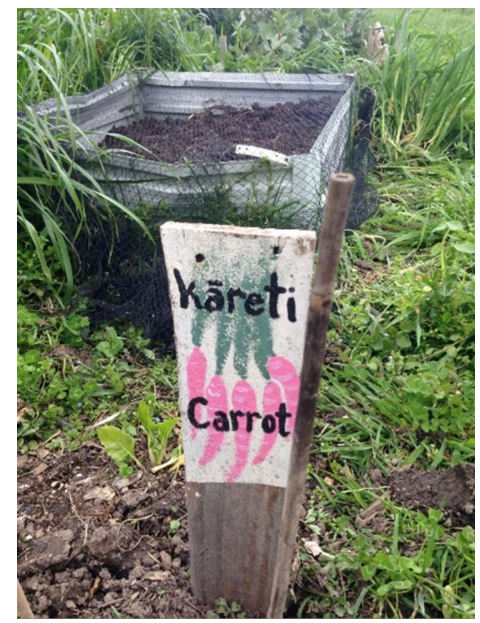

Figure 9: Sign in the Berhampore Orchard

The garden is working to orientate itself towards Aotearoa; the vegetable signs use Te Reo Māori before the English names and their two community events are Matariki and a day acknowledging the invasion of Parihaka. Chloe hopes next year they will make a trip to Parihaka to learn from the kaitiaki still cultivating gardens there, still advocating peaceful resistance and still sharing their knowledge. ${ }^{276}$ These are slight movements in a country still navigating its colonial history, but they begin to crack open the space for the possibility of decolonisation of this landscape.

Hutchings aligns food sovereignty movements with wider indigenous sovereignty - in her words, "They speak to these global issues by acting locally... and leading the way in the return to eating the landscapes in which we live."277

Some rhythms in a garden are short, the daily open and close of the dandelion flower; others are much longer. The long lifespan of the piñon means that the trees that helped sustain de Vaca and Esteban may still be being harvested to this day. The

\footnotetext{
276 Angela Clifford, 'Return to Parihaka.', Stone Soup, 29 August 2019, https://stonesoupsyndicate.com/features/return-to-parihaka/.

277 Hutchings, Te Mabi Mãra Hua Parakore, 43.
} 
kūmara varieties that pre-date colonisation are treated as taonga by the gardeners who still cultivate them. These are a reminder of the continuity of the relationships in reciprocal capture..$^{278}$

Kimmerer writes, "food plants and people act as selective forces on each other's evolution - the thriving of one is the best interest of the other." ${ }^{279}$ Broad beans (Vicia faba) exemplify this co-evolution - they are entangled with humanity to such an extent they are a plant only known in cultivation. ${ }^{280}$ Kimmerer takes the concept of reciprocity a further step:

Something essential happens in a vegetable garden. It's a place where if you can't say "I love you" out loud, you can say it in seeds. And the land will reciprocate, in beans. ${ }^{281}$

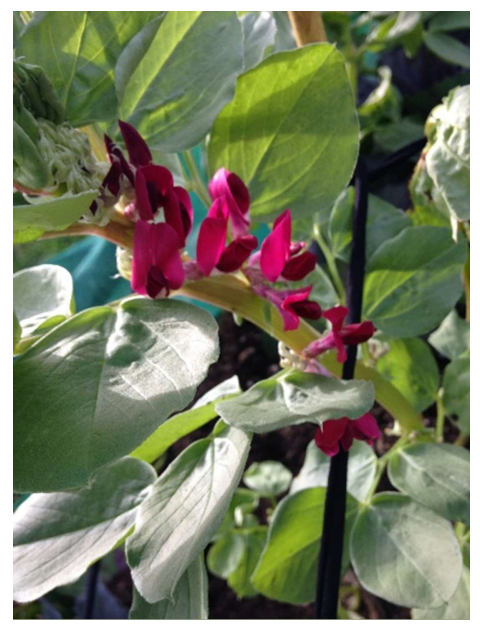

Figure 10: Broad beans in the Khandallah garden

It was late spring, and, after a week of blustery winds and side-ways rain, the sun was out to warm the Earth. I arrived at Innermost Gardens near the end of a Tuesday working bee to meet Chris for our second interview. A full crop of gardeners had turned up to enjoy the sun and the soil. Everyone was packing down and I loitered

278 Rose, Reports from a Wild Country, 25.

${ }^{279}$ Kimmerer, Braiding Sweetgrass, 124.

${ }^{280}$ T. K. Lim, 'Vicia Faba', in Edible Medicinal And Non-Medicinal Plants: Volume 2, Fruits, ed. T. K. Lim (Dordrecht: Springer Netherlands, 2012), 925-36, https://doi.org/10.1007/978-94-007-1764-0_97.

${ }^{281}$ Kimmerer, Braiding Sweetgrass, 127. 
around watching the productive scene. One group was shelling freshly harvested broad beans destined to be consumed as dip at the next Mt Victoria community dinner. The gardeners had also been enjoying the beans raw from the garden, eating in Chris's words the "fruits of the garden."

When I ask Chris what vegetables she likes eating, her answers are centred around what is easy to grow in a community garden. She describes having so much silverbeet recently that they could drop it down to the Downtown Community Ministry's soup kitchen. Chris tells me she has been eating, and enjoying, a lot of broad beans. She never had them as a kid; her mother was put off after being made to eat overcooked broad beans in her own childhood. Chris describes her mother as a gardener, but not a vegetable gardener. "Her dad used to do a lot of vegetable gardening. When she was growing up it was seen as 'poor people do vegetable gardening.' When she could afford not to, she stopped."

Chris's recollection of her mother's reluctance to grow and eat her own vegetables shows changing attitudes through generations. Goodall recognises that each practice we perform around food is imbued with meaning: "Each has a history, and each involves the performance of social power." ${ }^{282}$ Attitudes to food production change from generation to generation responding to ideas of class, gender, race and culture: gardening for food is more complex than simple access and ability. ${ }^{283}$

The community gardens I have visited are not urban farms. They produce enough to supplement a diet rather than sustain one. Chris considers that Innermost Gardens could easily transform: "We are not a highly productive garden, but we could snap if we had to." The Tuesday garden sessions have made a large contribution. This working bee has been running since 2018 and increased garden days per month from two to six, "It has made such a difference in the general upkeep of the garden, things just are not getting away from us." Chris thinks of the community gardens as more than the gardening - it is a space to gather and connect:

I just get joy out of being around here, I get joy out of seeing the kids and how they have grown, and I really enjoy seeing the Tuesday ladies and having a chat. These are people I wouldn't normally bump into. Innermost is a bit of a

\footnotetext{
282 Goodall, "Rivers, Memory and Migrancy." 32

${ }^{283}$ Hondagneu-Sotelo, 'Cultivating Questions for a Sociology of Gardens'. 499
} 
melting pot. As it should be, it is the all welcome church, a modern day

church. Everyone is welcome here.

Community connections brought Chris to Innermost Gardens a couple of years ago.

She's now the lead of the Tuesday garden mornings.

Chris has observed that the Tuesday gardeners are quite a distinct group in comparison to the Sunday working bee. The Tuesday group is made up of the "kids" and the "ladies". The kids are part of an organisation supporting people with learning disabilities; coming to the garden is about making community connections and getting active. The ladies are mostly retired women who work their gardening around grandparenting and trips out of town. "On a Tuesday you sometimes have to slow yourself down. It is a good way of working to the strengths of your different groups."

Kimmerer suggests the reciprocity between humans and the plants that sustain us can teach us about reciprocity within our species too. ${ }^{284}$ At Innermost Gardens. the Tuesdays work because a space is made for everyone. One of the kids will hand-weed convolvulus each week, keeping the new native plantings free from weeds, others have flourished into leadership roles - keen to show off the skills they've learnt after a year in the garden. Here individuals grow alongside the plants, illustrating Kimmerer's suggestion that "when the individuals flourish, so does the whole." 285

${ }^{284}$ Kimmerer, Braiding Sweetgrass, 134.

${ }^{285}$ Kimmerer, 134. 


\section{Dirt under your fingernails: gardening as care in practice}

Laugier writes that "care is a practice that is hard work, not a moral feeling or disposition." ${ }^{\text {286 }}$ Caring is central to the community gardens I have visited. Not abstractly as a concept but as a verb. This act of caring is made easier by a sense of reciprocity back from the garden, the Earth loving gardeners back, to reverberate Kimmerer. ${ }^{287}$ This process of caring and being cared for in return can provide hope, but it is hope grounded in hard work. Care for a garden is frequently intergenerational, an act that reminds gardeners of family members they learnt from and those they hope will come after. This serves as a reminder of the many lives and deaths tangled up inside the patchy Anthropocene.

What Laugier suggests in her writing on the ethics of care is that it is an ordinary process. ${ }^{288}$ These are the life stories of Le Guin, the everyday acts we undertake to keep ourselves, and our loved ones, alive. ${ }^{289}$ Instead of looking for heroic gestures, it is time for tangible care.

"Feel free to drop by and 'love the garden'."

It was a sunny, but windy, day in the Khandallah Community Garden. Jenny, Kate and I were seated around the picnic table, braceing against the occasional gusts of wind. Kate's dog provided appropriate contributions to the conversation through intermittent barks. It was a peaceful place to be, though Kate remarked that while the combination of sun and garden picks up her spirit the wind is a challenge. They'd returned to me the bucket and the fork that I'd enthusiastically brought and then left at the last working bee. ${ }^{290}$

\footnotetext{
${ }^{286}$ Laugier, 'Politics of Vulnerability and Responsibility for Ordinary Others', 213.

287 Kimmerer, Braiding Sweetgrass, 127.

${ }^{288}$ Laugier, 'Politics of Vulnerability and Responsibility for Ordinary Others', 207.

${ }^{289}$ Le Guin, 'The Carrier Bag'.

${ }^{290}$ It now lives underneath my desk at university in case any garden emergencies arise.
} 
Kate and Jenny have both been involved in the community garden since its formation five years ago. Kate's children were at the primary school across the road

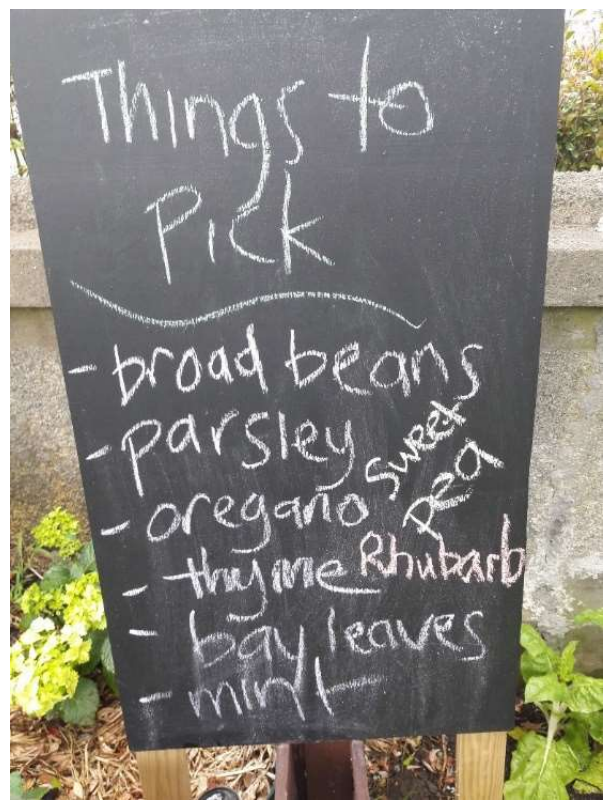

Figure 11: Things to pick in Khandallah,. Image supplied by Jenny and, after discussions with another mum, a group was formed to start a community garden in this patch. The idea was a place that kids could come and ask, "what's that?" Kate provided me with their background document outlining the garden's purpose and how it works: "It's also about reconnecting with the environment and regaining the knowledge we have lost as a community, and about how to care for ourselves and our environment in a sustainable way."291

The active number of gardeners is small; Kate describes them as a companionable group that just gets on and

does things. They think of their gardening style as a muddle - responding to the challenges they face, big or small, with good humour. They tell me about the time somebody stole their alpaca poo. The story is frequently interrupted by lots of laughter at the shared memory. Back when they were still setting up, someone sourced them bags of alpaca poo to fertilise the garden. But before they could use them, they vanished. Weeks went by and no one knew where it had gone, and they could only assume that it had been stolen. Annoyance at the theft was mixed with hilarity at imagining the face of the thief upon opening their stolen goods. In the end, it was found that the bags had been accidentally taken by the council rubbish collectors, but the story has become part of the history of the community garden.

They've also faced larger hurdles - the discovery that most of the lot couldn't be dug in, or a lack of mains water access. One surprising challenge has been convincing the community that they can harvest from the garden. It is hard to know how much gets harvested, the apples do get picked, but often before they are ready. Jenny told me they'll find the trees bare and it's not windfall, none of the fruit can be

${ }^{291}$ Khandallah Community Garden, 'Background Document', 2018. 
seen on the ground. It could be birds, but I'm reminded of eating unripe fruits as a kid to experience the thrill of a sour-face pucker or throwing small hard apples at each other as part of a game.

They operate with minimal resources; Kate explained their strategy is to "beg, borrow, and steal. Well not so much steal... re-purpose." For example, using free coffee grounds as a soil conditioner. They are practical in what gets planted - dwarf trees that can be accommodated in small spaces and plants, like broad beans and silverbeet, that they know will be okay on their own. Later, Jenny sends me a photo (Figure 11) showing what crops are ready to be collected in springtime. To her it shows what the garden is about, there for anyone who wants to enjoy it. Kate agreed, "The community side of it is, for me, more important than the gardening." Echoing the words of Kimmerer, the hope is that community members will drop by, read a book or pull out some weeds, and "love the garden" 292

For Jenny "I just like looking at it, and I like picking and eating things. I like the sense of accomplishment, taking something from the garden and then cooking with it... I don't particularly love it, gardening, it is just a thing you have to do." We laughed, and I asked what makes her keep doing it, now she's on the record as stating such a blasphemous opinion. Though we joke that she shouldn't think about it too much in case the façade comes down, Jenny doesn't seem perturbed, "someone has to do it, and I couldn't bear not to have a garden." There's more to it than that, she's also motivated by giving something to the community and finds the activity can be soothing, "Once I get into it I can sit and weed for hours... it's a mindful thing for me."

For Jenny, thinking of the big picture between the garden and the Anthropocene, "It is all very complicated, if we can encourage more green spaces that is a good thing, but the changes the world needs are way beyond people's gardens." Kate concluded "We are starting a conversation... people can come here and have conversations together, see what a vege looks like. It is the start of a conversation. I think we are contributing in our own way; each community garden brings its own thing."

\footnotetext{
${ }^{292}$ Khandallah Community Garden.
} 
With limited time, people, and resources, Kate and Jenny are not sure what will happen to the garden in the future. They'd like to see it flourishing but they don't have a long-term plan. They told me honestly that, "We don't have an answer to that one."

Soil stained fingers

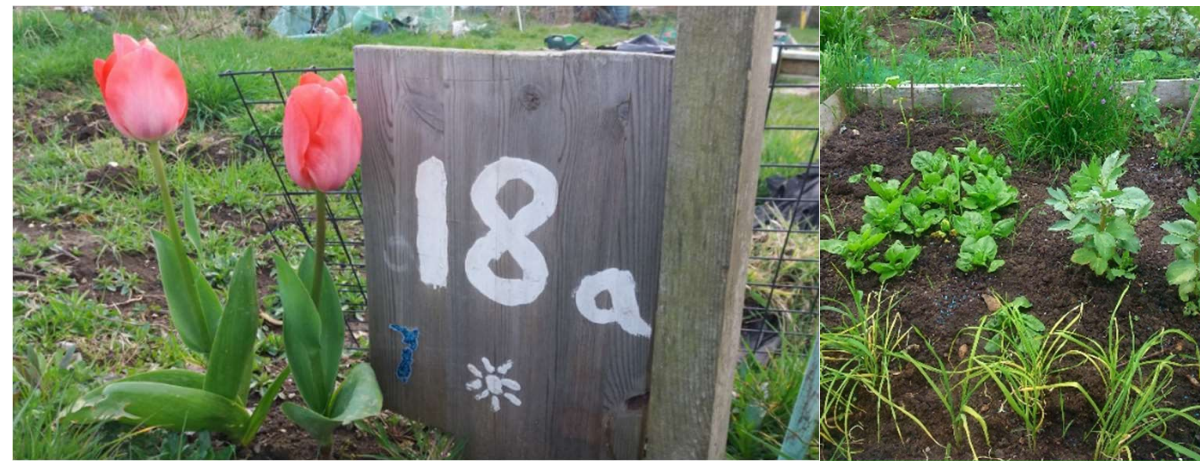

Figure 12 Wendy's allotment in the United Kingdom. image supplied by Wendy

At Innermost Gardens there is a portion of the garden given over to allotments. There is a long waiting list for these plots so, in an attempt to meet demand over winter, an unused area was turned into three new ones. It was while helping with the creation of these that I encountered the squirm of worms. These allotments allow those living nearby a patch to call their own. But they are required to care for them and participate in the wider garden too. Wendy is the current kaitiaki of these garden beds. Periodically, she will wander between the plots and check to see if it looks like they are being cultivated and cared for. If a bed looks like it needs some attention, she will gently send a reminder that gardens require tending.

Wendy currently lives in an apartment. In her dream garden, she would have lots of flowers, a wisteria, jasmine, and lemon trees; "All the lovely things that take up space." She's never had a big garden, but her love of gardening means she actively seeks out community gardens. It is the easiest way to get her hands in the soil, "I haven't got a particular love of vegetable gardening. Just gardening in general."

Wendy's first exposure to gardening came from her mother. The impetus for gardening grew when she owned her own home. In New Zealand that meant pot plants and then, when she moved to the United Kingdom (UK), she pulled up a concrete backyard and re-made it as an ornamental garden. This was just the beginning. Wanting more space, she found a nearby community garden with 
allotments. In her UK allotment, she raised courgettes, beans, beetroot, garlic, onions and an array of "really weird shaped squashes, which you didn't know what to do with." Wendy sent me two photos of her allotment in England (Figure 12 Wendy's allotment in the United Kingdom). One shows the allotment planted with crops. The second is a close-up of her allotment number, complete with tulips and a small sticker of Aotearoa.

She was surrounded by gardeners who had been there for years. "All around me were people who had been there quite a long time." Wendy would go to her allotment on weekends and in the longer summer evenings. The others around her were retired and able to spend more time there. "My learning certainly came from those people who tended their allotments."

Through this garden Wendy observed how a garden changed year to year, often without clear cause, “One year you'd get so many courgettes, then next year you'd get too many beetroots, and you don't know why." Sometimes she was able to attribute it to the weather, "One time it was wet in April and it ruined it for the rest of the year." Accepting this uncertainty is an important thread between the gardeners and their gardens.

Wendy returned to Aotearoa in February 2019, which meant leaving that garden behind. She is now acclimatising after decades living in the United Kingdom (U.K.). She tells me that to her the garden smells like damp earth, the smell she associates with forests in Aotearoa. Returning home to visit while she lived in the UK, she always noticed it. She struggled to tell me exactly what the smell is.

I can't describe it, the smell of the bush, the New Zealand bush and leaves on the ground is different than the UK - It is usually when you are in the bush that you get that, that is the smell of New Zealand for me. The UK doesn't seem to have that smell, I don't know if that is just me and my sense of smell or what my brain does.

Wendy went on to suggest that this smell ties into the taste of the plants too, something she's seen frequently, "You always see gardeners do that if they see something they don't know, they'll pick it and taste it. It is a way of connecting with the Earth."

Wendy calls gardening a stress release; this sentiment is repeated throughout my conversations with gardeners. For example, for Chloe the garden is a healing space, with the sun adding another dimension to it, "I have been enjoying the sun's presence 
recently. The garden is a spiritual place for me. The sun ties into those concepts - I don't connect to the word god, but energy - the sun frames the space like that for me." Having a garden space available is important to Jan, "It is getting out and seeing things grow and develop, it is very therapeutic, it is good for your soul. If you are stuck in a concrete apartment, it is very important that you have somewhere you can just come." There is very little that will stop Jan making time to visit the Berhampore spot. "In everything except torrential rain, I would probably come to the garden." Jan's words remind me of Kimmerer's description of standing in the forest in the rain. "Listening, standing witness, creates an openness to the world in which the boundaries between us can dissolve in a raindrop." 293 A powerful way to see yourself as connected to the environment around you.

Wendy, upon returning to Wellington, looked for a community garden and found Innermost Gardens in Mt Victoria. She came along on a Tuesday and, in my words, fell in love. "It was just ideal, just perfect. It is lovely." She has not yet harvested from the garden but sees that as a by-product of the practice of community gardening rather than the purpose in itself.

It is the feel of the soil. It is the smell. The excitement of the plants germinating and the whole growth cycle. Seeing the fruits of your labour. Definitely coming here is re-homing myself. I noticed there was a woman today who has just come back to Wellington after a while; it is a great way to ground yourself to a place. There was a French man who came here one day. He had been living on a boat and he came because he felt he needed to get his fingers back into the land.

Our relationships with places are sensory - here the community garden becomes a space to connect with a new landscape and begin to re-home yourself. ${ }^{294}$ Consider Wendy's words above, the feel of the soil, the need to get fingers back into the land, the idea of grounding oneself. Terms all alluding back to a gardener's connection to the stuff landscapes are made of, soil. Puig de la Bellacasa makes the connection between soil and care. She suggests that what the world needs right now is not "innovation" but commitment to "the work of care." 295

\footnotetext{
${ }^{293}$ Kimmerer, Braiding Sweetgrass, 300.

${ }^{294}$ Goodall, 'Rivers, Memory and Migrancy', 45.

295 Puig de la Bellacasa, 'Making Time for Soil', 207.
} 
Wendy sees gardening as providing common bond between people and a sense of achievement. "A couple of hours here and then you feel as if you have done something with the day... contributed... a sense of achievement and accomplishment." This sense of achievement can come in the tangible outcome of weeding a garden bed or digging over new ground. The action may be small, and repetitive, but it creates a sense of having done something. ${ }^{296}$ Wendy is pragmatic in her approach to the world's environmental issues. "I am just trying to do what I can in terms of growing and composting. Helping the earth as it is now. I think if you worry too much it can be counterintuitive."

I asked Wendy what gives her hope and she tells me, gesturing to Innermost Gardens, "What we have here... friendships, learning, eating. Learning would be top of my list. I think of how much I've learnt even just today. You'd think it would be exhausted but it is never exhausted." Learning is repeated as a motivation in almost every interview I completed, often it is the reason that individuals became involved in the first place. Frequently gardeners continue to see themselves as novices, despite the fact that they have many years of gardening experience behind them.

Chloe is very mindful of cultivating a space where gardeners can gain knowledge. In fact, learning about gardening was why Chloe started volunteering at a community garden. When she began at Common Ground, she told me, "It was all about education, educating myself and then applying that knowledge." Her garden mentor at Common Ground took the attitude that there were many ways to garden and nothing would be considered wrong, "She would not ever give you any answers, she'd get you to explore for yourself and experiment."

Over time, Chloe moved from novice to someone people asked questions of. Suddenly, she realised, "I was one of the oldies and I was meant to know what I was doing." Her first response was "Oh my god, I have no idea!" The realisation motivated her to enrol in a night class on organic gardening. At the orchard, Chloe finds people come to the garden with all levels of knowledge; they may not know how to plant a seed or what could be considered a weed. Sometimes they need more guidance than the 'give it a go' attitude. Chloe told me a story of walking someone

\footnotetext{
296 This sense of achievement is explored in Harriet Gross and Nicola Lane, 'Landscapes of the Lifespan: Exploring Accounts of Own Gardens and Gardening', Journal of Environmental Psychology 27, no. 3 (1 September 2007): 226, https://doi.org/10.1016/j.jenvp.2007.04.003.
} 
Regeneration

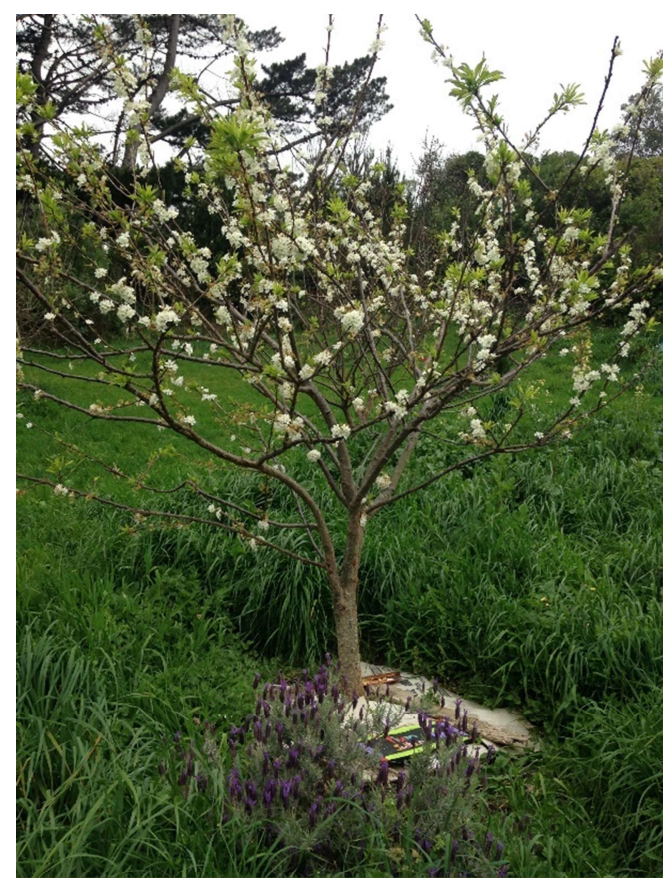

Figure 13: Apple tree in blossom then Community Orchard

Spring is a lovely time to visit a garden; there is lush green growth and fruit trees in flower. It brings into mind gardens as utopian or agrarian paradises. The exact sort of gardens that Tsing warns against idealising. She considers gardens are spaces that promote control and simplified relationships that benefit humans. ${ }^{303}$ Tsing instead points to uncultivated landscapes as "good to think with" as they challenge a humancentric view. ${ }^{304}$ In contrast, my experience of community gardens suggests that human control is tentative, and both intra and inter-species relationships are not simple.

Spring brings into relief the dynamic nature of a landscape. The lush green growth, that looks so promising from a distance, may be those unsought after plants, known as weeds, elbowing out planted seedlings. And every time southerlies blow through Wellington, there's a risk all the blossoms will be lost, and with them a year's harvest.

303 Anna Lowenhaupt Tsing, 'Blasted Landscapes (and the Gentle Arts of Mushroom Picking)', in The Multispecies Salon, ed. Eben Kirksey (Durham: Duke University Press, 2014), 115.

304 Tsing, 116. 
I grew up reading the Greek myths, so spring means the return of Persephone to her mother, Demeter, after the dark of winter in/with Hades. Spring can be a season of hope and rebirth, but the myth makes clear none of it exists without a time for grieving and death. It is a reminder that the stories we tell matter. Kimmerer contrasts two creation stories, that of Eve being evicted from a garden for daring to harvest, and that of Skywoman "who created a garden for the well-being of all." 305 In one mindset, humanity is ever questing to return back to paradise from the wilderness; in the other, humanity is part of the ecosystem.

Buck raises the idea of becoming enchanted with the connections between human and nature; she suggests that gardens are places where we can build intimate relationships between ourselves and the Earth. Not the glorified and romantic garden where nature sits on a pedestal for humans to gaze on. Like Kimmerer suggests, this is a reciprocal relationship where humans try their best to listen and then hear the Earth saying it loves us back. ${ }^{306}$ This is the imperfect garden, subject to weeds and bad weather, where gardeners stand muddily and messily rooted into the landscape.

The process of learning from family about how to grow was a common thread through the stories I was told. Wendy summed it up as, "My gardening comes from my mother. It is normally a family thing, from your mother or father." Similarly, Gross and Lane, in their research, found that connecting to childhood and past generations through gardening was an important theme amongst the gardeners they talked to. ${ }^{307}$

It is important to come back to the idea of layers of the past and possible future layering across our landscapes. The impacts of environmental degradation, be it local concentrations of DDT or global concentrations of $\mathrm{CO}_{2}$, are in most part felt collectively and frequently across generations. Gaynor writes, "As such, many propose that sustainability — in terms of both intergenerational and intragenerational equityrequires solutions which rely on collective and cooperative approaches." 308

As well as connecting to the past, gardening cultivates connections to the future. All my gardeners are mothers or grandmothers with children of various ages. For several the birth of their own children was something that inspired them to return

\footnotetext{
${ }^{305}$ Kimmerer, Braiding Sweetgrass, 7.

306 Kimmerer, 127.

${ }^{307}$ Gross and Lane, 'Landscapes of the Lifespan', 238.

308 Gaynor, Harvest of the Suburbs, 194.
} 
to gardening themselves. Connections to gardens can be about connections to homemaking, and mothers with young children have been identified as a group who increasingly garden. ${ }^{309}$

Alison started gardening when she had little kids. For her a garden and children have a lot in common, "each day they continue to grow and make messes." There is a lot of repetition of tasks and a slow build to achievement. Alison was motivated to show children how plants grow and now, as adults, they both know how to garden. She told me, "Now I am educating my grandsons, one is quite keen, the other would rather be at the computer. But he lives with me, so he has to learn stuff. He has learnt a lot about compost making and putting seeds in the ground."

Similarly, it wasn't until Chris had kids that she started gardening on her own. It was around the same time that Lynda Hallinan was embarking on her year of only eating what she grew. ${ }^{310}$ Chris marks Hallinan as one impetus behind her getting gardening, inspired by her honest account of the trials of eating what you grow.

One year my three-year-old got a packet of snow pea seeds and they just planted them everywhere. It was amazing! We just ate them off the plant. Cherry tomatoes are great like that too with little kids. I remember going to playcentre, when my eldest was just tiny, and a little boy coming up to me and saying 'I found lollies in the garden.'

In Chris's day-job, she is working to understand what motivates young people to take political action around the environment. She's found that the schooling system, from pre-school to college, increasingly moves away from the soil. She's heard that some teachers are reluctant to come to the garden as they are a bit smelly. She wonders if she is biased, but the compost smell doesn't seem such an issue anymore, "this is what a well-functioning garden should smell like."

Chris's next project is developing a child play space at Innermost. In an area that has always been swampy, she will place a collection of river stones and a large macrocarpa trunk. She tells me that if children haven't walked on an uneven surface by age seven, they can't develop the skill. "It is about being able to think two steps ahead, where are you going to put your feet on this uneven surface.” A skill we all need to be working on as we approach an uncertain future.

\footnotetext{
${ }^{309}$ Hondagneu-Sotelo, 'Cultivating Questions for a Sociology of Gardens', 500.

${ }^{310}$ Lynda Halligan was the editor of NZ Gardening.
} 
She is conscious that it is more important to get kids under ten outside, and building a relationship with their environment, than it is to educate them on the facts of climate change. "When they are older and they find out about the crappy stuff that is happening, they will have such an attachment and love for this thing (Earth) that they will want to take action. Otherwise you just panic them, and you have a whole lot of anxious kids."

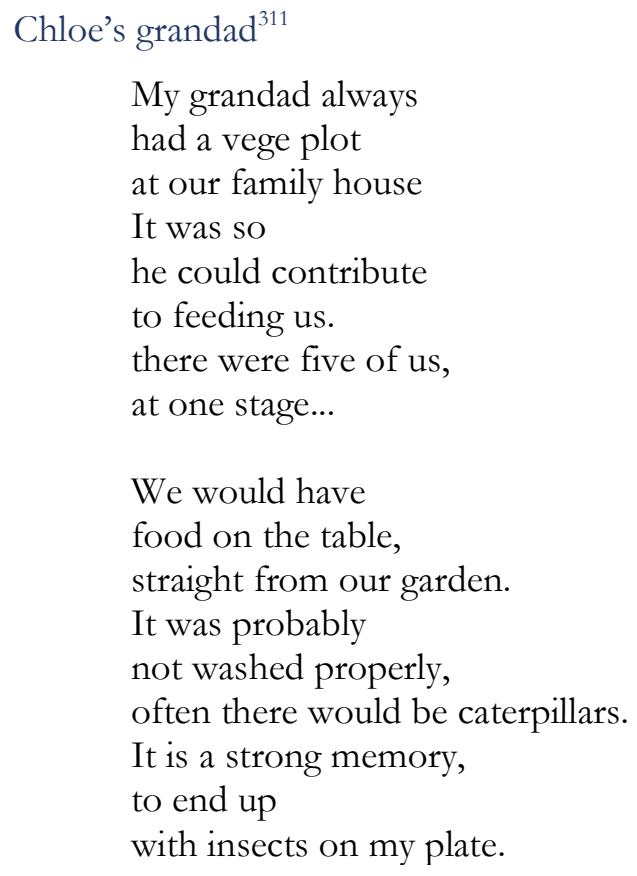

Chloe gardens with her son M. on Mondays, and she tells me that this is what keeps her going. "I want him to feel connected to this place... I didn't want him to have the lost feeling I had from moving so many times." Chloe sends me a picture of M. holding a worm. It's not in great focus but you can just see the worm clasped in his fingertips. He is an energetic toddler so keeping him interested while she is weeding is sometimes a challenge, but worms are helping her maintain his excitement.

It is one of the ways that $\mathrm{M}$ actually engages with the garden... it is something that is really exciting and strange, 'it's a worm!', but he calls it a noke...that is

311 A found poem drawn from Chloe's interview. 
his go to now. I was doing some weeding with him and he said, 'I saw a noke!' I was like 'Woah, there is something I can keep this exciting with' thankfully! 312

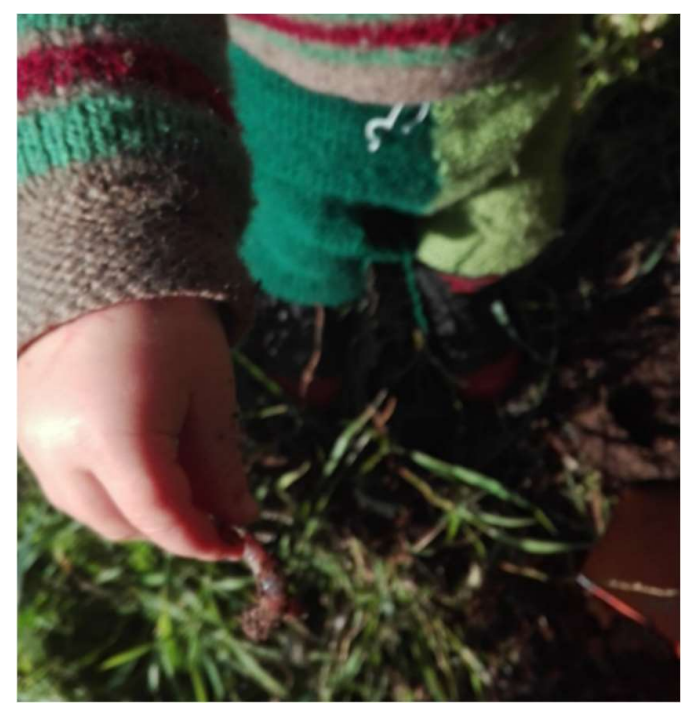

Figure 14: M. and a noke, image supplied by Chloe

Chloe talks about gardening in terms of childbearing. She tells me, "If you are going to give birth to a child, you need to know you are going to commit to that child. That is what I feel about any ideas you try and put into the garden... you can't just start it up and walk away."

Chloe says, "There are so many different ways of engaging in the space... and actually so many right ways of engaging with the space, but they sometimes clash with each other." An example being the native plants in between the apple trees. Chloe admits she was bemused about Cathy's attitude to planting and protecting natives, "I thought she was going off on a tangent... now I totally get it. Now it is totally in line with what I want to do!"

Cathy, like Chloe, sees coming to the garden as important, "This is our family time - we choose to spend it in the garden." She has always been into gardening as a thing, though she laughs that her first experience was indentured labour. Growing up on a farm in Southland, Cathy helped look after their home garden that fed six people - it was half a paddock with swedes, carrots, cabbages and spuds. For her father it was a point of pride that they would eat food from their own farm.

312 Noke is the te reo Māori word for worms. 
Thinking of a future where more people grow their own food, Jan is realistic. "People need to return to eating a lot more simply if they are going to eat from the garden. We've got used to being able to buy whatever we want and not think about where it comes from. But living on what you grow is darn hard work." This echoes Laugier's writing that the transformation humanity needs will take hard work - caring is a practice that requires turning up. ${ }^{313}$

The Berhampore orchard often has food harvested early - people will strip the trees even when there is an "unripe" sign on them. The gardeners accept that there is not much you can do about that unless you have it all walled up - and that would miss the point. There is an acceptance that both human and non-human activity in the garden is somewhat outside of their control. Cathy and Chloe tell me about a "ninja gardener" who created a new garden bed and maintained it, all without them knowing who it was. Nettle observed this same phenomenon in the community gardens she studied in Australia. She found that community gardens, due to their collective management, are "eccentric and unique." 314 The landscape of these gardens reflects active care from a variety of humans working to create something as part of a collective. $^{315}$

The gardens I have visited are all open to their communities, no barriers prevent anyone walking in and harvesting. This openness, or vulnerability, can occur in these gardens because the risks are low, as Chloe suggested, mostly the communities are not dependent on the gardens for food. Cathy describes a community garden as a strong, but small, core group linking into broader networks. She's aware that, "Sometimes it is just about sitting around eating scones and drinking tea - it is a great connecting space. Building community becomes increasingly important as the world goes into a more perilous place."

I asked Chloe if she is worried about the perilous places we might be heading and she told me, "I'm not really terrified of climate change, as I am actively able to do something." She relates this to the grief cycle, "some people really need to be doing something... it looks like they are not crying and grieving but that is how they deal with it, by being active." She does, however, know many people who are terrified and is

\footnotetext{
${ }^{313}$ Laugier, 'Politics of Vulnerability and Responsibility for Ordinary Others', 213.

314 Nettle, Community Gardening as Social Action, 100.

315 Nettle, 100.
} 
working on facilitating the involvement of younger people in the garden, "I do see this as a space for young people to be, they are feeling the most terrified and concerned."

In ten years, Chloe hopes the garden will have taken over the entirety of the golf course. She thinks that young people are the ones who are most passionate about climate change and hopes they will be around to help maintain an expanded garden. Her personal hope is that the garden will provide a space of relaxation: "I see success as people chilling out in this space, and being able to relax from the stress of being alive today. Becoming a calming area, not owned by anyone. Somewhere that you give what you can, as in your time, but with no pressure."

I asked Chloe "what is gardening?" and she told me gardening is about reciprocity - harvesting without giving back is not gardening. She starts to reflect that "gardening is showing another way of being, that manaakitanga is... brings just as much..." then pauses and tells me "I do not like the words coming out of my mouth!" She stops and then goes on, "My hope is that people can see another way of being... we don't have to be driven by greed. By having the courage and vulnerability to give, you will also be receiving." I relate Chloe's thinking to Kimmerer's suggestion that a gift is not given without expectation. A gift, similar to communities and gardens, should be taken care of, especially when given in the spirit of reciprocity. In Kimmerer's word, "Gifts multiply by our care for them and dwindle from our neglect." 316

During the year, the community orchard held a visioning session. Jan suggested two values that were important to her, action and commitment. She was pleased when those two words were identified by the collective as what the group felt connected to. "I am not a person who likes to throw ideas around over an email. I would like to be actually doing something. There is a lot of work that needs to get done." This is an important reminder that hope is not enough, the challenge is to take hope and transform it into action. ${ }^{317}$

\footnotetext{
${ }^{316}$ Kimmerer, Braiding Sweetgrass, 382.

317 Rose, Reports from a Wild Country, 32.
} 
What can we do? ${ }^{318}$

It was the hottest

summer last summer,

It is scary.

I can see it happening,

It scares me a lot.

We are thinking,

what can we actually

do about it?

What can we do?

318 Drawn from my interview with Jan. 


\section{Conclusion}

I have made a compost from the words of the gardeners, the thoughts of the thinkers, and the process of gardening. From the compost three tendrils sprout: patches, entanglements, and care. These concepts overlap, or perhaps more aptly intertwine.

Patches embody the gardens, relationships to landscapes, and the ways that they are part of the patchy Anthropocene. We layer names onto landscapes, Wellington over Te Whanganui a Tara, like we name layers in the landscape, Anthropocene over Holocene. The hills become Khandallah and Khandallah becomes a suburb. An unloved corner of a suburban intersection, a cross-road of fallen empires, becomes a garden where gardeners cultivate companionship and care. The raised beds and cheerful signs obscure the tangle of wires and pipes that prevent gardeners digging below the surface.

The patchy Anthropocene lies unevenly across the landscape. Sometimes it is hard to see, but if you stop and squint, then dig a little you'll find it. There's wire under that patch, this compost is built from coffee - the most currently capitalised plant in the world, and those garden beds are raised to avoid heavy metals. On a hillside the gorse forgets itself and shrugs off its role patrolling the border. Instead it becomes a nursery for native seedlings. Tradescantia escapes into the margins (who are we to tell it where to grow?) smothering out the light for those same native seedlings. Plantain does what it has done for millennia and crops up in the wayside of human activity.

In the midst of the patchy Anthropocene there are so many stories to tell. On an ancient riverbed I saw a blackbird eat a worm. It was enough to make me squirm. They are descendants of the colonial era: the blackbirds were kidnapped migrants, brought to Aotearoa to make settlers feel at home; squirming worms were incidental stowaways in soil stashed on ships. They've both made new homes here, learnt new landscapes, found new gardens. An octopus garden, with one lost limb, takes us into the tentacular landscapes of the Chthulucene. Staying with the trouble means stirring things up, instead of burying our heads. ${ }^{319}$

\footnotetext{
${ }^{319}$ Haraway, Staying with the Trouble.
} 
Entanglements are the complex multispecies relationships between humanity and these thriving, or barely surviving, creatures we inhabit patches with. I found an old bowling green drenched in DDT that became a home for oyster mushrooms: they broke down the toxic chemicals, so the soil could be cultivated again. It became a garden that smells of compost, a patch of liveability. This life is sustained by human entanglements with multispecies and maintained through hard work and care(fullness). The garden became a modern-day church; in Chris's words, "As inclusive as possible, for the plants, the people and the bugs."

The old bowling green became a food forest, carefully laid out so that tropical plants can thrive in the sunniest and most sheltered spot. The two banana plants receive individual consideration: they are composted and cocooned in frost-cloth. Without care they can't live here. We've learnt to live with, and garden with, the Wellington weather. We wear wind breakers and drink hot cups of tea. We wait till winter to plant the brassicas and begin to change what we grow, season by season. Hoping that we will be warned. A lifetime ago, in Rhodesia, a country now gone, bananas grew like weeds in Alison's garden. In large patches of the Anthropocene, plantations grow. There bananas receive detached attention, distanced from diverse entanglements, and virulence has flourished.

Weeds and gardeners form another complex entanglement. Gardening means weeding, an action undertaken in gardens to benefit some species at the expense of others. I found divergent views among the interviewed gardeners concerning what belongs where and the need to be adaptive in gardening practice. The boundaries humans construct between nature and humanity are flimsy. The paradox of weeds, plants humans don't want to entangle with, forces us to consider with care our impact on wider ecosystems.

Our most intimate entanglements are with the species that offer us sustenance. For several gardeners, growing their own food is part of their way of addressing their concerns about the environmental impacts of commercial agriculture, food miles, and food packaging. What we eat ties into the ideas of both interspecies reciprocity, the plants humans care for so as to be sustained by them, and intraspecies reciprocity, the ways humans can care for each other. ${ }^{320}$ On the soil of Aotearoa, reciprocity between

\footnotetext{
${ }^{320}$ Kelley, 'Plumpiñon'.
} 
peoples and our multispecies kin is explored through the history of kumara and potatoes and the impacts of colonisation on tangata whenua. Allowing space for differences to flourish makes our collective entanglements stronger. ${ }^{321}$

We seek out patches of liveability to care for so we, and the companion species we entangle with, might survive. The four community gardens I visited in Wellington are patches of liveability. Not conceptual or metaphorical community gardens but “smells-like-compost-and-gets-mud-on-your-jeans" gardens. The gardeners don't necessarily love gardening, but they do love the garden. In these gardens, I found that caring requires more than good thoughts, it also requires hard work. ${ }^{322} \mathrm{I}$ have learnt how to improve my hole digging and I have learnt how to create a frame for broad beans. I have seen gardeners sweat as they shovel compost and heard of how they turn up each week at the same time, just to give space for someone who might want to learn.

Some of us worry. What is next? Was this summer hotter than the last? What exactly can we do? Community gardening is a quiet, but still legitimate, form of activism. ${ }^{323}$ The challenge - how is gardening different to other ways the human interventions have damaged the landscape? Well it isn't by default. But here, in these four patches, you can see the difference. More importantly, the gardeners can feel the difference. The gardeners nurture the garden and are nurtured by the garden in return. I propose that we cultivate gardens because cultivating heroes hasn't done us any good. ${ }^{324}$

Over time gardeners come and go, garden beds are built and dismantled, crops are sown and harvested. A constant process of renewal, growth and death takes place. Will the Berhampore tree house be finished? How long will the bananas survive at Innermost Gardens? What will happen next at Khandallah given the gardeners admit not knowing themselves? As individuals and collectives, the ongoing environmental change of the Anthropocene, even in its patchiness, can create a sense of hopelessness. The impacts will be both inter-generational and inter-species. Gardening allows for

\footnotetext{
${ }^{321}$ Kimmerer, Braiding Sweetgrass.

322 Laugier, 'Politics of Vulnerability and Responsibility for Ordinary Others'.

${ }^{323}$ Nettle, Community Gardening as Social Action.

${ }^{324}$ Le Guin, 'The Carrier Bag'.
} 
action at a manageable scale, in the local patches we are able to access. ${ }^{325}$ There is hope and there is care located in community gardens; they nurture community and connections to other species. But there are also material challenges - the different ideas, the physical effort, the time commitment. To keep going requires the gardeners to keep caring.

Gardeners are not heroes and gardens are not paradise. These stories are ones without end - they follow the seasons, they repeat. They sit within the troubles. They are real places with all the mess and muddle that comes with that. These things do not just happen, they require hard work. So yes, gardening is a practice that might help us but not unconditionally and not without facing the uncomfortable realities of living in the Anthropocene.

325 Di Paola, 'Gardens and the Anthropocene', 1. 
Epilogue

I could ramble on for ages, gardening is like that.

Alison

By the calendar year we were in the first days of summer, but a storm had blown in and the sun hadn't shown its face in several days. The day was blustery, there were wind warnings in place. At Tawa Community Garden the garden border was more vibrant ever and I spotted Alison already at work pulling off tomato laterals.

Alison does not normally attend the weekend working bees, she loves croquet and too often a good gardening day is also a good croquet day. Instead she's made Wednesday mornings her regular time. She says it is normally just her, but she does not seem too bothered by that. She was frustrated to find that someone had pulled out the potato plants too early. Compounded by the fact that this happened last year as well. The frustration is not that someone is harvesting them, but that they are harvesting them before they are ready.

The broad beans I planted with her in winter were ready to come out and they hadn't done well. Something Alison attributed to a poor winter growing season and a lack of bees due to wind. Before we could pull them up and start them on the decomposing cycle, we had to sort out the compost. And so, I learnt to dance with the Tawa compost bins. Armed with a shovel, I transported the 'ready' compost onto the asparagus bed (largely done for the season). Then the contents of the 'leave' bin move into the 'ready' bin and the contents of the "Use" bin moved into the 'leave'.

With the dance completed we returned to the broad bean bed. Each plant was pulled up, roots and all, and chopped into smaller pieces. As the broad bean fragments are tossed into the compost, we discussed whether the compost smell will stay with me as I walk the halls of university. I enjoyed the symmetry of being at the garden at the end of the broad beans' life, but nothing really ends in a garden, the cut up broad beans were about to start another journey - to nourish new plant life in the garden. As Alison told me, "Nothing is a waste, it will make good compost." 


\section{Bibliography}

Ahmed, Sara. 'Making Feminist Points'. Feministkilljoys (blog), 11 September 2013. https://feministkilljoys.com/2013/09/11/making-feminist-points/.

Anderson, Deb. 'Hearing the Legacy in the Forecast: Living with Stories of the Australian Climate'. In Telling Environmental Histories: Intersections of Memory, Narrative and Environment, edited by Katie Holmes and Heather Goodall, 26794. Cham: Springer International Publishing, 2017. https://doi.org/10.1007/978-3-319-63772-3_11.

Anderson, Grahame. 'Wakefield Towns'. In Edward Gibbon Wakefield and the Colonial Dream: A Reconsideration., by Friends of the Turnbull Library, 143-58. Wellington: Friends of the Turnbull Library, 1997.

Atchison, Jennifer. 'Thriving in the Anthropocene: Understanding Human-Weed Relations and Invasive Plant Management Using Theories of Practice'. In Social Practices and Dynamic Non-Humans: Nature, Materials and Technologies, edited by Cecily Maller and Yolande Strengers, 25-46. Cham: Springer International Publishing, 2019. https://doi.org/10.1007/978-3-319-92189-1_2.

Bagge, Michael L.S. 'Valuable Ally or Invading Army? The Ambivalence of Gorse in New Zealand, 1835-1900'. Australian \& New Zealand Environmental History Network (blog), 19 March 2014. https:/ /www.environmentalhistory-aunz.org/2014/03/valuable-ally-or-invading-army-the-ambivalence-of-gorse-innew-zealand-1835-1900/.

Baker, Hinemoana. 'Ka Aro Au (Cuba Street Song)'. Pukeahu Anthology. Accessed 7 February 2020. http://pukeahuanthology.org/stories/migrations/ka-aro-au$2 /$.

Beatley, Timothy. 'Wellington, New Zealand: From Town Belt to Blue Belt'. In Handbook of Biophilic City Planning and Design, 75-84. Washington, DC: Island Press, 2016. https://doi.org/10.5822/978-1-61091-621-9_7.

Beattie, James. 'Climate Change, Forest Conservation and Science: A Case Study of New Zealand, 1860s-1920'. History of Meteorology 5 (December 2009): 1-18.

. 'Plants, Animals and Environmental Transformation: Indian-New Zealand Biological and Landscape Connections, 1830s-1890s'. In The East India Company and the Natural World, edited by Vinita Damodaran, Anna Winterbottom, and Alan Lester, 219-48. London: Palgrave Macmillan UK, 2015. https://doi.org/10.1057/9781137427274_11.

Bernard, H. Russell. Research Methods in Anthropology: Qualitative and Quantitative Approaches. Sixth edition.. Lanham, Maryland: Rowman \& Littlefield, 2018. https://ebookcentral.proquest.com/lib/vuw/detail.action?docID $=5113478$.

Bethel, Rosalie, Paul Kroskrity, Christopher Loether, and Gregory Reinhardt, eds. $A$ Dictionary of Western Mono. n.p., 1993. http:// northforkrancheriansn.gov/home/showdocument?id=29.

Buchanan, Rachel. 'Beating Shame: Parihaka and the Very Long Sorry'. Te Poubere Korero Māori History, Māori People 6 (2012): 55-82.

_. Ko Taranaki Te Maunga. Wellington: Bridget Williams Books, 2018. 
Buchanan, Rachel, and Maria Tumarkin. 'Bread and Breath: Two Reflections on the Ethics of (Doing) History'. Australian Humanities Review, no. 52 (May 2012).

Buck, Holly Jean. 'On the Possibilities of a Charming Anthropocene'. Annals of the Association of American Geographers 105, no. 2 (4 March 2015): 369-77. https://doi.org/10.1080/00045608.2014.973005.

Bunn, Christian, Peter Läderach, Juan Guillermo Pérez Jimenez, Christophe Montagnon, and Timothy Schilling. 'Multiclass Classification of AgroEcological Zones for Arabica Coffee: An Improved Understanding of the Impacts of Climate Change'. PLOS ONE 10, no. 10 (27 October 2015): e0140490. https://doi.org/10.1371/journal.pone.0140490.

Bunn, Christian, Peter Läderach, Oriana Ovalle Rivera, and Dieter Kirschke. 'A Bitter Cup: Climate Change Profile of Global Production of Arabica and Robusta Coffee'. Climatic Change 129, no. 1 (1 March 2015): 89-101. https://doi.org/10.1007/s10584-014-1306-x.

Butcher, Ellen R., and Dave Kelly. 'Physical and Anthropogenic Factors Predict Distribution of the Invasive Weed Tradescantia Fluminensis'. Austral Ecology 36, no. 6 (2011): 621-27. https://doi.org/10.1111/j.1442-9993.2010.02196.x.

Clayton, Neil. 'Weeds, People and Contested Places'. Environment and History 9, no. 3 (1 August 2003): 301-31. https://doi.org/10.3197/096734003129342863.

Clifford, Angela. 'Return to Parihaka.' Stone Soup, 29 August 2019. https://stonesoupsyndicate.com/features/return-to-parihaka/.

Wellington City Council. 'Community Gardens'. Accessed 19 February 2019. http://wellington.govt.nz/services/community-and-culture/communitygardens.

'Community Orchard Berhampore and Island Bay Photos'. Accessed 10 February 2020. https: / / www.facebook.com/photo.php?fbid=10154286950338336\&set=g. 940 $700659376768 \&$ type $=1 \&$ theater\&ifg $=1$.

Wellington City Council. 'Wellington City Council Guidelines for Community Gardens'. Community Gardens, n.d., 9.

Davis, Aaron P., Tadesse Woldemariam Gole, Susana Baena, and Justin Moat. 'The Impact of Climate Change on Indigenous Arabica Coffee (Coffea Arabica): Predicting Future Trends and Identifying Priorities'. PLOS ONE 7, no. 11 (7 November 2012): e47981. https://doi.org/10.1371/journal.pone.0047981.

Dawson, John, and Rob Lucas. New Zealand's Native Trees. 2nd ed. Nelson: Potton \& Burton, 2019.

Di Paola, Marcello. 'Gardens and the Anthropocene'. In Ethics and Politics of the Built Environment: Gardens of the Anthropocene, edited by Marcello Di Paola, 1-34. The International Library of Environmental, Agricultural and Food Ethics. Cham: Springer International Publishing, 2017. https://doi.org/10.1007/978-3-31971166-9_1.

Dooren, Thom van, Eben Kirksey, and Ursula Münster. 'Multispecies Studies Cultivating Arts of Attentiveness'. Environmental Humanities 8, no. 1 (1 May 2016): 1-23. https://doi.org/10.1215/22011919-3527695. 
Dooren, Thom van, and Deborah Bird Rose. 'Lively Ethography Storying Animist Worlds'. Environmental Humanities 8, no. 1 (1 May 2016): 77-94. https://doi.org/10.1215/22011919-3527731.

Eggleton, Paul, Kelly Inward, Joanne Smith, David T. Jones, and Emma Sherlock. 'A Six Year Study of Earthworm (Lumbricidae) Populations in Pasture Woodland in Southern England Shows Their Responses to Soil Temperature and Soil Moisture'. Soil Biology and Biochemistry 41, no. 9 (September 2009): 1857-65. https://doi.org/10.1016/j.soilbio.2009.06.007.

'Eurasian Blackbird | New Zealand Birds Online'. Accessed 10 February 2020. http://nzbirdsonline.org.nz/species/eurasian-blackbird.

Farah, Adriana. COFFEE: Production, Quality and Chemistry. London: Royal Society of Chemistry, 2019.

Friesen, Timothy L. 'Combating the Sigatoka Disease Complex on Banana'. PLOS Genetics 12, no. 8 (11 August 2016): e1006234. https://doi.org/10.1371/journal.pgen.1006234.

Gan, Elaine, Anna Lowenhaupt Tsing, Heather Swanson, and Nils Bubandt. Arts of Living on a Damaged Planet: Ghosts of the Anthropocene. Minneapolis: University of Minnesota Press, 2017.

Gan, Elaine, Anna Tsing, Heather Swanson, and Nils Bubandt. 'Introduction: Haunted Landscapes of the Anthropocene'. In Arts of Living on a Damaged Planet-Ghosts and Monsters of the Anthropocene, edited by Elaine Gan, Anna Tsing, Heather Swanson, and Nils Bubandt, 1-15. Minneapolis: University of Minnesota Press, 2017.

Gay, Paul. 'Lettuce Give Thanks to Chinese Miners'. Stuff, 31 October 2018. https://www.stuff.co.nz/southland-times/news/features/108237017/lettucegive-thanks-to-chinese-miners.

Gaynor, Andrea. Harvest of the Suburbs: An Environmental History of Growing Food in Australian Cities. Crawley: University of Western Australia Press, 2006.

Gibson, Katherine, Rose, Deborah Bird, and Fincher, Ruth, eds. Manifesto for Living in the Anthropocene. Brooklyn:punctum books, 2015. https://doi.org/10.21983/P3.0100.1.00.

Gibson, Lorena. 'A Template for Writing Fieldnotes'. Anthropod (blog), 14 August 2013. https://anthropod.net/2013/08/14/a-template-for-writing-fieldnotes/.

GNS Science. 'The Geology of New Zealand'. GNS Science. Accessed 16 February 2020. https://www.gns.cri.nz/Home/Our-Science/Land-and-MarineGeoscience/Regional-Geology/The-Geology-of-New-Zealand.

Goldson, S. L., G. W. Bourdôt, E. G. Brockerhoff, A. E. Byrom, M. N. Clout, M. S. McGlone, W. A. Nelson, A. J. Popay, D. M. Suckling, and M. D. Templeton. 'New Zealand Pest Management: Current and Future Challenges'. Journal of the Royal Society of New Zealand 45, no. 1 (2 January 2015): 31-58. https://doi.org/10.1080/03036758.2014.1000343.

Goodall, Heather. 'Rivers, Memory and Migrancy: Everyday Place-Making in Changing Environments'. In Telling Environmental Histories: Intersections of Memory, Narrative and Environment, edited by Katie Holmes and Heather Goodall, 31-50. Cham: 
Springer International Publishing, 2017. https://doi.org/10.1007/978-3-31963772-3_2.

Grace, Patricia. Baby No-Eyes. Auckland: Penguin Books, 1998.

Grace, Wiremu. 'Ngake and Whātaitai the Taniwha of Wellington Harbour'. Home Mātauranga Māori. Accessed 6 February 2020. http://eng.mataurangamaori.tki.org.nz/Support-materials/Te-ReoMaori/Maori-Myths-Legends-and-Contemporary-Stories/Ngake-andWhataitai-the-taniwha-of-Wellington-harbour.

Gross, Harriet, and Nicola Lane. 'Landscapes of the Lifespan: Exploring Accounts of Own Gardens and Gardening'. Journal of Environmental Psychology 27, no. 3 (1 September 2007): 225-41. https://doi.org/10.1016/j.jenvp.2007.04.003.

Hamilton, Jennifer Mae. 'Gardening out of the Anthropocene: Creating Different Relations between Humans and Edible Plants in Sydney'. In Covert Plants: Vegetal Consciousness and Agency in an Anthropocentric World, edited by Prudence Gibson and Baylee Brits, 221-51. Santa Barbara, CA: punctum books, 2018.

Hamilton, Jennifer Mae, and Astrida Neimanis. 'Composting Feminisms and Environmental Humanities'. Environmental Humanities 10, no. 2 (1 November 2018): 501-27. https://doi.org/10.1215/22011919-7156859.

Haraway, Donna. 'Anthropocene, Capitalocene, Plantationocene, Chthulucene: Making Kin’. Environmental Humanities 6, no. 1 (1 May 2015): 159-65. https://doi.org/10.1215/22011919-3615934.

- Staying with the Trouble: Making Kin in the Chtbulucene. Experimental Futures. Durham: Duke University Press, 2016. When Species Meet. Minneapolis: University of Minnesota Press, 2007.

Hatfield, Gabrielle. Hatfield's Herbal: The Secret Society of British Plants. London: Penguin, 2007.

Holmes, Katie. 'Gardens'. Journal of Australian Studies 23, no. 61 (January 1999): 152-62. https://doi.org/10.1080/14443059909387485.

Holmes, Katie, and Heather Goodall. 'Introduction: Telling Environmental Histories'. In Telling Environmental Histories: Intersections of Memory, Narrative and Environment, edited by Katie Holmes and Heather Goodall, 1-27. Cham: Springer International Publishing, 2017. https://doi.org/10.1007/978-3-319-63772-3_1.

Hondagneu-Sotelo, Pierrette. 'Cultivating Questions for a Sociology of Gardens'. Journal of Contemporary Ethnography 39, no. 5 (October 2010): 498-516. https://doi.org/10.1177/0891241610376069.

Hulme, Mike. 'Climate'. Environmental Humanities 6, no. 1 (1 May 2015): 175-78. https://doi.org/10.1215/22011919-3615952.

—. Weathered: Cultures of Climate. London: SAGE Publications, 2016.

Hulme, Philip. 'Ornamental to Detrimental: The Invasion of NZ by Non-Native Plants'. Presented at the Royal Society of New Zealand, 2018. https://www.youtube.com/watch?v=8hhBlZe6toc.

Hutchings, Jessica. Te Mabi Māra Hua Parakore: A Māori Food Sovereignty Handbook. Ōtaki: Te Tākupu, Te Wānanga o Raukwa, 2015. 
Hutchings, Jessica, Jo Smith, and Garth Harmsworth. 'Elevating the Mana of Soil through the Hua Parakore Framework'. MAI Journal: A New Zealand Journal of Indigenous Scholarship, 2018. https://doi.org/10.20507/MAIJournal.2018.7.1.8.

Industries, Ministry for Primary. 'About the One Billion Trees Programme'. Accessed 6 February 2020. https://www.teururakau.govt.nz/funding-andprogrammes/forestry/one-billion-trees-programme/about-the-one-billiontrees-programme/.

'Innermost Gardens'. Accessed 11 February 2020. https://sites.google.com/view/innermostgardens.

Instone, Lesley, and Affrica Taylor. 'Thinking About Inheritance Through the Figure of the Anthropocene, from the Antipodes and in the Presence of Others'. Environmental Humanities 7, no. 1 (1 May 2016): 133-50. https://doi.org/10.1215/22011919-3616371.

Kapahi, Meena, and Sarita Sachdeva. 'Mycoremediation Potential of Pleurotus Species for Heavy Metals: A Review'. Bioresources and Bioprocessing 4, no. 1 (2017). https://doi.org/10.1186/s40643-017-0162-8.

Kelley, Lindsay. 'Plumpiñon'. In The Multispecies Salon, edited by Eben Kirksey, 161-75. Durham: Duke University Press, 2014.

Kelly, Dan, and Jessica Hutchings. 'Sovereignty, Kai, and the Land Where We Grow'. Stone Soup, 29 August 2019.

https://stonesoupsyndicate.com/features/sovereignty-kai-and-the-landwhere-we-grow/.

Kelly, Dave, Jenny J. Ladley, Alastair W. Robertson, Sandra H. Anderson, Debra M. Wotton, and Susan K. Wiser. 'Mutualisms with the Wreckage of an Avifauna: The Status of Bird Pollination and Fruit-Dispersal in New Zealand'. New Zealand Journal of Ecology; 34, no. 1 (2010): 66-85.

Kema, Gert HJ. 'One Super-Susceptible Clone, a Versatile Fungus and Failing Fungicides - Black Sigatoka and Banana’. Plos Biologue (blog), 12 August 2016. http://blogs.plos.org/biologue/?p=10284.

Khandallah Community Garden. 'Background Document', 2018.

Kiddle, Rebecca, Chantal Mawer, Ceara McAuliffe Bickerton, Alyssa Ryan, and Laurette Siemonek. 'E Hoa Ma, Ina Te Ora o Te Tangata (My Friends, This Is the Essence of Life): Meal-Making as a Pedagogical Tool for Learning about Food Politics'. Policy Futures in Education 17, no. 7 (1 October 2019): 805-20. https://doi.org/10.1177/1478210318819209.

Kimmerer, Robin. Braiding Sweetgrass: Indigenous Wisdom, Scientific Knowledge and the Teachings of Plants. Minneapolis, United States: Milkweed Editions, 2014.

Kirksey, Eben. The Multispecies Salon. Durham: Duke University Press, 2014.

Kirksey, S Eben, Nicholas Shapiro, and Maria Brodine. 'Hope in Blasted Landscapes'. Social Science Information 52, no. 2 (2013): 228-56. https://doi.org/10.1177/0539018413479468.

Laugier, Sandra. 'Politics of Vulnerability and Responsibility for Ordinary Others'. Critical Horizons 17, no. 2 (May 2016): 207-223.

Le Guin, Ursula K. 'DEEP IN ADMIRATION'. In Arts of Living on a Damaged Planet, edited by Anna Tsing, Heather Swanson, Elaine Gan, and Nils Bubandt, 15- 
21. Ghosts and Monsters of the Anthropocene. Minneapolis: University of Minnesota Press, 2017. https://www.jstor.org/stable/10.5749/j.ctt1 qft070.19.

. 'The Carrier Bag Theory of Fiction'. In Dancing at the Edge of the World: Thoughts on Words, Women, Places, 1st ed. New York: Grove Press, 1989.

Leach, Helen. 1,000 Years of Gardening in New Zealand. Wellington: Reed, 1984.

Lim, T. K. 'Vicia Faba'. In Edible Medicinal And Non-Medicinal Plants: Volume 2, Fruits, 925-36. Dordrecht: Springer Netherlands, 2012. https://doi.org/10.1007/978-94-007-1764-0_97.

Lutz Warren, Julianne. 'Huia Echoes'. In Future Remains: A Cabinet of Curiosities for the Anthropocene, edited by Gregg Mitman, Marco Armiero, and Robert Emmett. Chicago: University of Chicago Press, 2018. http://ebookcentral.proquest.com/lib/vuw/detail.action?docID=4914481.

Lyon, Thomas J. 'A Taxonomy of Nature Writing'. In The Ecocritism Reader, 276-80. Athens, Georgia: University of Georgia Press, 1996.

Mart, Michelle, and Cameron Muir. 'The Manual Pesticide Spray Pump'. In Future Remains: A Cabinet of Curiosities for the Anthropocene, edited by Gregg Mitman, Marco Armiero, and Robert Emmett. Chicago: University of Chicago Press, 2018.

Massey University, New Zealand. 'Couch'. Massey University. Accessed 15 January 2020. https://www.massey.ac.nz/massey/learning/colleges/college-ofsciences/clinics-and-services/weeds-database/couch.cfm.

Matthews, Robin F. 'Claytonia Perfoliata'. Fire Effects Information System, 1993. https://www.fs.fed.us/database/feis/plants/forb/claper/all.html.

McCarrol, Jo. 'The History of Gardening in New Zealand: Revealed by 75 Years of NZ Gardener'. NZ Gardener, September 2019. https://www.stuff.co.nz/lifestyle/homed/115385521/the-history-of-gardening-in-new-zealand-revealedby-75-years-of-nz-gardener.

McDonald, Tein, and David Lamb. 'Forest Regeneration on Hinewai Reserve, New Zealand: An Interview with Hugh Wilson'. Ecological Management \& Restoration 18, no. 2 (2017): 92-102. https://doi.org/10.1111/emr.12261.

Merriam-Webster. 'Baharampur'. In Merriam-Webster's Geographical Dictionary, 2007. https://search-credoreferencecom.helicon.vuw.ac.nz/content/title/mwgeog?institutionId=5378\&tab=entry _view\&heading $=$ baharampur\&sequence $=0$.

'Miscellaneous.' Wellington Independent, 2 October 1862.

Mitich, Larry W. 'White Man’s Foot: Broadleaf Plantain’. Weed Technology 1, no. 3 (1987): 250-51.

'Municipal Golf Links.' New Zealand Herald, 1 November 1915.

Myers, Natasha. 'From the Anthropocene to the Planthroposcene: Designing Gardens for Plant/People Involution'. History and Anthropology 28, no. 3 (27 May 2017): 297-301. https://doi.org/10.1080/02757206.2017.1289934.

Nettle, Claire. Community Gardening as Social Action. Farnharm, Surrey: Ashgate Publishing Company, 2014. https://doi.org/10.4324/9781315572970. 
New Zealand Plant Conservation Network. 'Plantago Lanceolata'. New Zealand Plant Conservation Network. Accessed 4 February 2020.

http://www.nzpcn.org.nz/flora_details.aspx?ID=3019.

Nixon, Rob. 'The Anthropocene: The Promise and Pitfalls of an Epochal Idea'. In Future Remains: A Cabinet of Curiosities for the Anthropocene, edited by Gregg Mitman, Marco Armiero, and Robert Emmett, 1-18. Chicago: University of Chicago Press, 2018.

'Notes on the Road Home'. Otago Witness, 27 July 1872.

Officer of the Surveying Staff. 'The Motuaka District.' Nelson Examiner and New Zealand Chronicle, 13 August 1842.

O'Gorman, Emily, Thom van Dooren, Ursula Münster, Joni Adamson, Christof Mauch, Sverker Sörlin, Marco Armiero, et al. 'Teaching the Environmental HumanitiesInternational Perspectives and Practices'. Environmental Humanities 11, no. 2 (1 November 2019): 427-60. https:/ / doi.org/10.1215/220119197754545 .

Papakura, Makereti. The Old-Time Maori. New Zealand Electronic Text Collection, 2005. Wellington: Victor Gollancz Ltd London, 1938. http://nzetc.victoria.ac.nz/tm/scholarly/tei-MakOldT.html.

Pascoe, Bruce. 'Forward: Recovering and Honouring Aboriginal Food Systems in Twenty-First-Century Australia'. In Reclaiming the Urban Commons : The Past, Present and Future of Food Growing in Australian Towns and Cities, edited by Nick Rose and Andrea Gaynor, 7-16. Crawley: UWA Publishing, 2018.

Pearce, Petra, Nava Fedaeff, Brett Mullan, Abha Sood, Bell Rob, Andrew Tait, Daniel Collins, and Christian Zammit. 'Climate Change and Variability - Wellington Region’. National Institute of Water \& Atmospheric Research Ltd, June 2019.

Pink, Sarah. Doing Visual Ethnography. London: SAGE Publications, 2007. https://doi.org/10.4135/9780857025029.

Pollan, Michael. Second Nature. 1st ed. New York, NY: Grove Press, 1991.

Pratt, Mary Louise. 'CODA:: CONCEPT AND CHRONOTOPE'. In Arts of Living on a Damaged Planet, edited by Anna Tsing, Heather Swanson, Elaine Gan, and Nils Bubandt, 169-76. Ghosts and Monsters of the Anthropocene. Minneapolis: University of Minnesota Press, 2017. www.jstor.org/stable/10.5749/j.ctt1qft070.14.

Priestley, Rebecca. Mad on Radium: New Zealand in the Atomic Age. Auckland: Auckland University Press, 2012.

Puig de la Bellacasa, Maria. 'Making Time for Soil: Technoscientific Futurity and the Pace of Care'. Social Studies of Science 45, no. 5 (1 October 2015): 691-716. https://doi.org/10.1177/0306312715599851.

Rei, Matiu. 'Edward Gibbon Wakefield: A Ngati Toa View'. In Edward Gibbon Wakefield and the Colonial Dream: A Reconsideration., by Friends of the Turnbull Library, 195-97. Wellington, N.Z: Friends of the Turnbull Library, 1997.

Rose, Deborah Bird. Reports from a Wild Country: Ethics for Decolonisation. Sydney: University of New South Wales Press, 2004. 
. 'Shimmer: When All You Love Is Being Trashed'. In Arts of Living on a Damaged Planet, edited by Elaine Gan, Anna Tsing, Heather Swanson, and Nils Bubandt, 51-63. Ghosts and Monsters of the Anthropocene. Minneapolis: University of Minnesota Press, 2017. www.jstor.org/stable/10.5749/j.ctt1qft070.7.

Roy, Bruce. An Illustrated Guide to Common Weeds of New Zealand. Edited by New Zealand Plant Protection Society. Lincoln: New Zealand Plant Protection Society, 1998.

Schiebinger, Londa L. Plants and Empire: Colonial Bioprospecting in the Atlantic World. Cambridge, Mass: Harvard University Press, 2004.

Singers, Nick, Philippa Crisp, and Owen Spearpoint. 'Forest Ecosystems of the Wellington Region'. Greater Wellington Regional Council, December 2018.

Small, Ernest. North American Cornucopia: Top 100 Indigenous Food Plants. Boca Raton: CRC Press, 2013.

Smith, Linda Tuhiwai. Decolonizing Methodologies: Research and Indigenous Peoples. 2nd ed. London; New York: Zed Books, 2012.

Star, Paul. 'Human Agency and Exotic Birds in New Zealand'. Environment and History 20, no. 2 (2014): 275-99.

'Te Māra Reo'. Accessed 16 February 2020. http://www.temarareo.org/PPNTawa.html.

The Beatles. Octopus's Garden. EMI Studio London: Apple, 1969.

The Bureau for the Appraisal of Societal Impacts and Costs. 'New Zealand Bananas: The Big Squeeze'. Fairtrade Australia and New Zealand, 2017.

'THE NEW ZEALAND GAZETTE', 19 August 1954. http://www.nzlii.org/nz/other/nz_gazette/1954/50.pdf.

Toft, Richard J., Richard J. Harris, and Peter A. Williams. 'Impacts of the Weed Tradescantia Fluminensis on Insect Communities in Fragmented Forests in New Zealand'. Biological Conservation 102, no. 1 (1 November 2001): 31-46. https://doi.org/10.1016/S0006-3207(01)00091-X.

Tsing, Anna Lowenhaupt. 'Blasted Landscapes (and the Gentle Arts of Mushroom Picking)'. In The Multispecies Salon, edited by Eben Kirksey, 87-109. Durham: Duke University Press, 2014.

. 'Dancing the Mushroom Forest'. PAN: Philosophy Activism Nature, no. 10 (2013): 6-14.

. 'Earth Stalked by Man'. The Cambridge Journal of Anthropology 34, no. 1 (2016): 2-16. https://doi.org/10.3167/ca.2016.340102.

—. 'Getting by in Terrifying Times'. Dialogues in Human Geography 8, no. 1 (1 March 2018): 73-76. https://doi.org/10.1177/2043820617738836.

'The Buck, the Bull, and the Dream of the Stag: Some Unexpected Weeds of the Anthropocene'. Suomen Antropologi: Journal of the Finnish Anthropological Society 42, no. 1 (26 June 2017): 3-21.

- The Mushroom at the End of the World: On the Possibility of Life in Capitalist Ruins. Princeton: Princeton University Press, 2015. 
Tuck, Eve, and Wayne Yang. 'Decolonization Is Not a Metaphor', 8 September 2012. https://www.researchgate.net/publication/277992187_Decolonization_Is_No t_a_Metaphor.

Velmourougane, Kulandaivelu, and Rajeev Bhat. 'Sustainability Challenges in the Coffee Plantation Sector'. In Sustainability Challenges in the Agrofood Sector, 61642. John Wiley \& Sons, Ltd, 2017. https://doi.org/10.1002/9781119072737.ch26.

Vet, Eliza de. 'Experiencing and Responding to Everyday Weather in Darwin, Australia: The Important Role of Tolerance'. Weather, Climate, and Society; Boston 9, no. 2 (April 2017): 141-54. http://dx.doi.org/10.1175/WCAS-D-15-0069.1.

_- 'Exploring Weather-Related Experiences and Practices: Examining Methodological Approaches'. Area 45, no. 2 (1 June 2013): 198-206. https://doi.org/10.1111/area.12019.

Waller, J.M., M. Bigger, and R.J. Hillocks. Coffee Pests, Diseases and Their Management. Wallingford: CABI, 2007.

http://ebookcentral.proquest.com/lib/vuw/detail.action?docID=315092.

'Wind Zones - LocalMaps'. Accessed 12 February 2020.

https://gis.wcc.govt.nz/LocalMaps/Viewer/?map=50f1b8e3d8594e3098b65d $698 a 7713 a 4$.

Woolf, Amber-Leigh. 'Khandallah's Homage to India'. Dominion Post, 2 October 2017.

Yeates, Gregor. 'Earthworms - Earthworms in New Zealand'. Te Ara - Encyclopedia of New Zealand, 24 November 2008. https://teara.govt.nz/en/earthworms/page3.

Zohary, Daniel, Ehud Weiss, and Maria Hopf. Vegetables and Tubers. Oxford University Press, 2012. 